\title{
MEDIEVAL FLANGED TILES FROM THE SOUTH-WESTERN CRIMEA: PROBLEMS OF PRODUCTION LOCALIZATION, TYPOLOGY AND CHRONOLOGY
}

This text is about the problem of typology, localization of the producing and dating of medieval building ceramics (Flanged tiles) of the South-Western Crimea. The investigation of products of tile production centers in the South-Western Crimea allowed to systematize a large complex of archaeological sources. They came from various archeological sites that were located throughout the region. Technological and morphological typology allowed to arrange and dating all this complexes and different material in some cases with an accuracy of up to two decades. The unified technological and morphological description and typology of the material described development and evolution of tile production craft in the South-Western Crimea trough the Medieval time. Therefore, this work could be a variant of a unified field guide for medieval Flanged tiles from Crimean sites and a chronological chart for them.

Keywords: flanged tile, building ceramics, SouthWestern Crimea, typology, chronology, tile production center.

Introduction. Medieval building ceramics of the South-Western Crimea is a unique archaeological material, which in many collections and complexes represents a significant part of them. Crimean medieval tiles are quite well represented in special scientific literature.

In the first works on medieval building ceramics of the South-Western Crimea the latter was typologized and dated based on its craft marks. Main works were made by A. L. Jacobson. He believed that medieval relief marks on building ceramics have the same origin and meaning as stamps on antique Flanged tiles. So these marks and side flanges were considered a dating feature (Якобсон 1979, с. 148). The next important work in the historiography was an article with materials from the southern coast of Crimea by O. O. Parshina (Паршина 1974). It was the first detailed technological description in the historiography. The classification of craft marks still kept its important place in the typologization (Паршина 1974 , с. $79-80,82-90$ ). In addition, Parshina's work opened the discussion about incorrect conclusions and methodology of A. L. Jacobson (Паршина 1974, с. 79). In his last work A. L. Jacobson couldn't give a reasoned answer to the criticism, which at this time was supported by other investigators apart from O. O. Parshina (Талис 1968, с. 189-190). However, Jacobson's works continue to be referred to, and his dating and methodology of typology remains relevant (Голофраст, Рыжов 2003, с. 192, 236, рис. 2; Рыжов, Седикова 1999, с. 323, 326).

The necessity to make corrections in the chronology of South-Western Crimea medieval building ceramics has led to the search of new methodological basis. An archaeological expedition of the Ural State University in Chersonesos designed the typology and dating of building ceramics based on craft marks, technology and morphology (Романчук 1976, с. $157-159 ; 1977$, с. $183-188$; 2004; Симонова 1980, с. 104-105). An essential work is a classic investigation about the roof tiles of medieval Kherson by A. I. Romanchuk (Романчук 2004).

However, in the late 80s articles about several sites (Bakla, Eski-Kermen, Isar-Kaya, Mangup, Partenit, Sotera, Chersonesos) were publicized which developed local technological classifications of building ceramics (Мыц 1987; 1990, с. 231 ; Паршина 1988, с. 37-39, 47; 1991, с. $71-73 ; 2002$, с. $120-121,123-124$; Рудаков 1984 , с. $39-40,45-46,48-49$; Сазанов 1999, c. 307-314). The legacy of A. L. Jacobson, of course, influenced the researchers, but these 


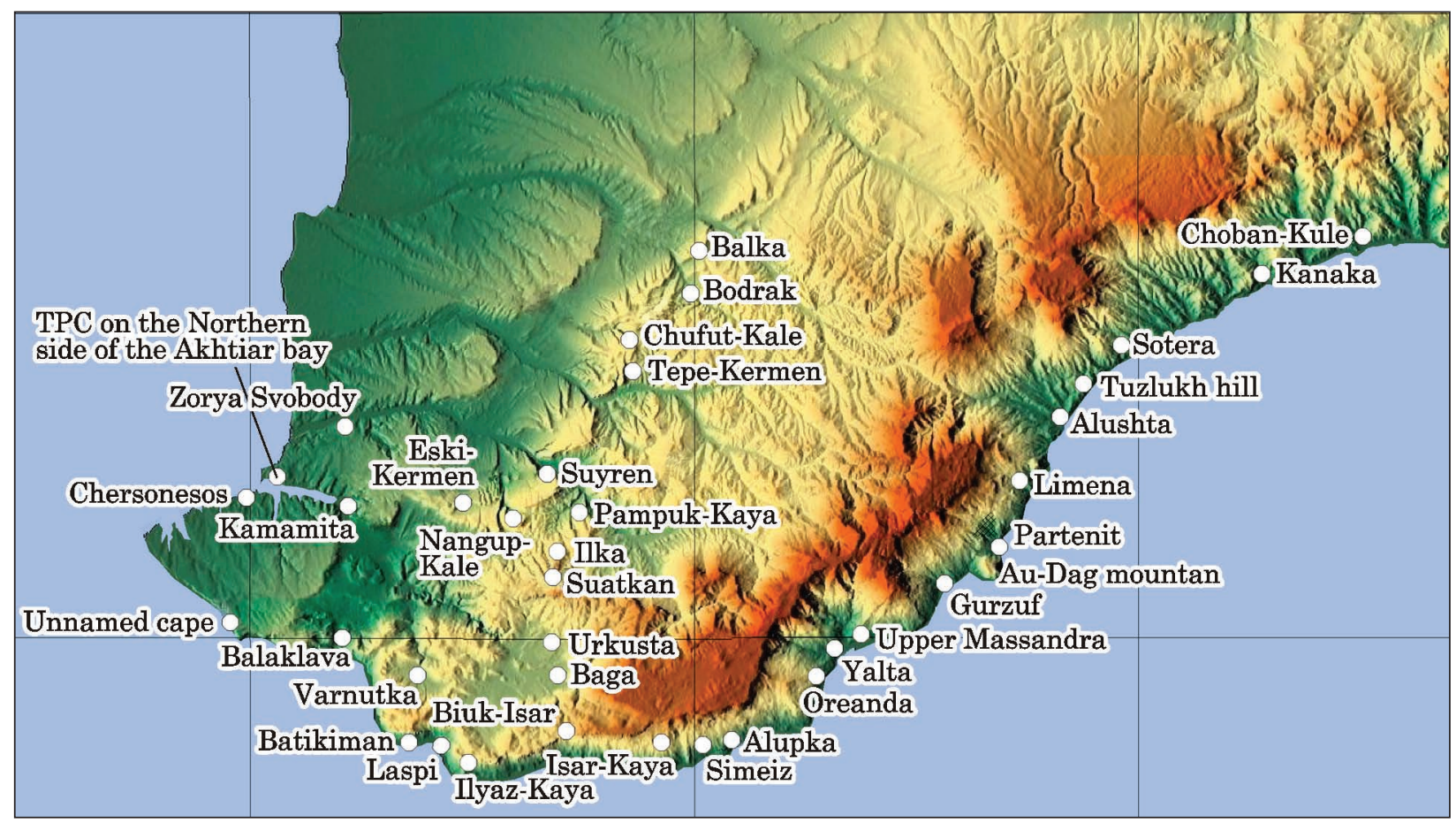

Fig. 1. Medieval archaeological sites on the map of the Crimea peninsula (digital elevation model SRTM)

works can't be called a complete repetition of his methods and this fact unites them with Romanchuk's investigations.

Therefore, at the beginning of the 2000s it became clear that Jacobson's works and conclusions about building ceramics are quite debatable. An important role played the fundamental study of building ceramics of Chersonesos by A. I. Romanchuk. Attempts to use the Jacobson's chronology led to its critique and became one of the main features of this stage of historiography development.

Typologization and dating of building ceramics by technology and morphology became an answer to this challenge (Лысенко, Тесленко 2002, c. 272-273; Науменко 1997, с. 325; Тесленко, Мусин 2015, с. 121-134).

There are new special studies of building ceramics, which generally belong to two authors: I. A. Zavadskaya with materials from Eski-Kermen (Завадская 2008; 2010) and the author of this article with materials from Eski-Kermen (Моисеев 2018b), Mangup (Моисеев 2011), Chersonesos (Моисеев 2013; Klenina et al. 2018) and its chora (Моисеев 2018a) and tile production center Ilka (Моисеев 2014a; 2014b).

At the base of Zavadskaya's work there is a local technological typology for building ceramics from Eski-Kermen supplemented by a modernized typology of craft marks (they are showed with the entire flanged tile only) (Завадская 2008, c. 294-304; 2010, c. 254). Main features of Zavadskaya's study are: attention to the study of full tile forms (Завадская 2008, с. 312—314; 2010, c. 256-259); narrow reliable dates of material base on a well-studied stratigraphy (Завадская 2008 , c. $294 ; 2010$, с. 253 ); the interpretation of the craft marks as "...unnecessary, namely... unorganized process» (Завадская 2008, с. 143144). I. A. Zavadskaya has also investigated the problem of tile production localization and places it on Eski-Kermen (Завадская 2008, с. 304305). These conclusions were proved to be incorrect, which over the time was recognized by the researcher herself (Завадская 2017, с. 160-161) under the influence of published data that formed the basis of this work (Моисеев 2014a, с. 279280, 300-302, рис. 2-4; Moisieiev 2018b).

Methodology. The methodology of building ceramics description system was designed during the work with material from excavations by Polish-Ukrainian interdisciplinary scholarly and research project «The Topography and Architecture of Chersonesos Taurica» in Chersonesos (blocks LX and XLV) (Klenina et al. 2018, p. 148-150) and successfully tested during the excavations of TPC Ilka in 2010-2013 (Моисеев $2014 \mathrm{a} ; 2014 \mathrm{~b}$ ) and work with museum collection from excavations of Eski-Kermen in 1936-1937 (Моисеев 2018b, с. 166). At least this article works with materials from 32 sites (supplement). Methodology system includes four categories (from general to individual): group (general technological features: qualities, color, methods of preparations and density of the ceramic paste, list of admixtures) - subgroup (individual technological features: shades of chip color, quantitative and qualitative composition of admixtures) ${ }^{1}$ - class (general morphological features,

1. The definition of subgroups in compact notation is $\mathrm{X} /$ $\mathrm{Y}$, where $\mathrm{X}$ is number of the group and $\mathrm{Y}$ is number of the subgroup. 


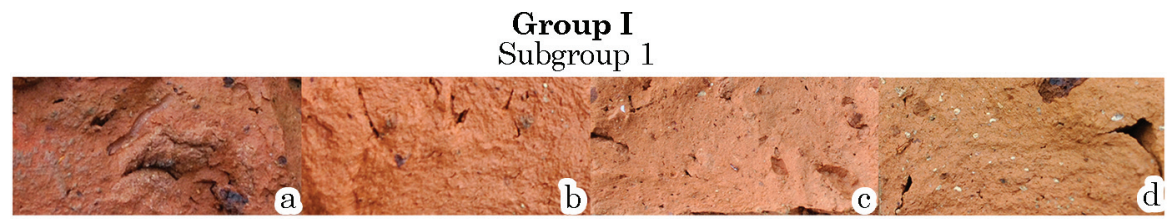

Subgroup 2

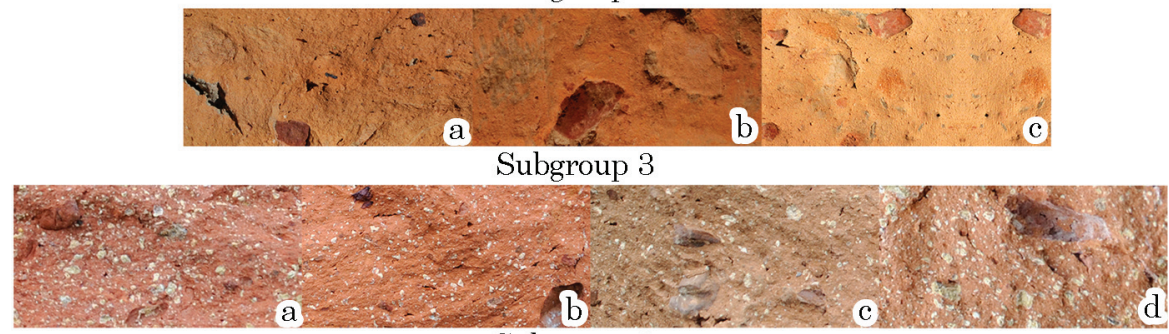

Subgroup 4

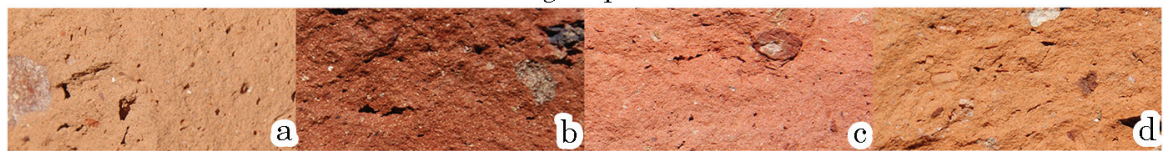

Subgroup 5

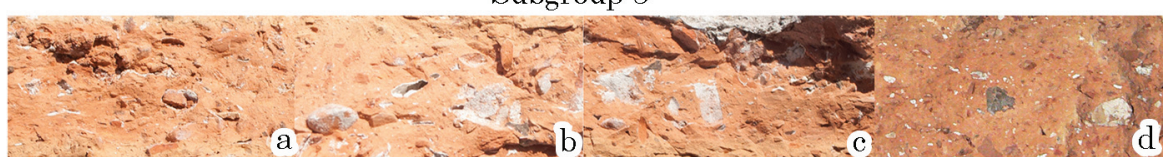

Subgroup 6

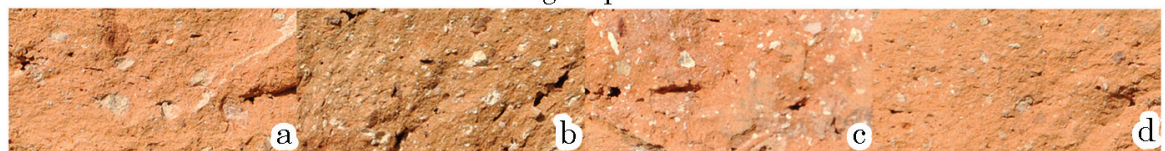

Group Ich by A. I. Romanchuk's typology (I Chersonesos)

Subgroup 1

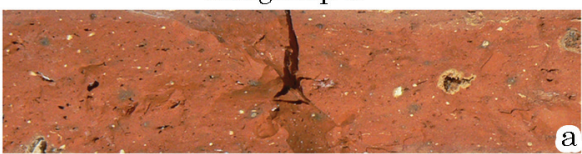

Subgroup 2

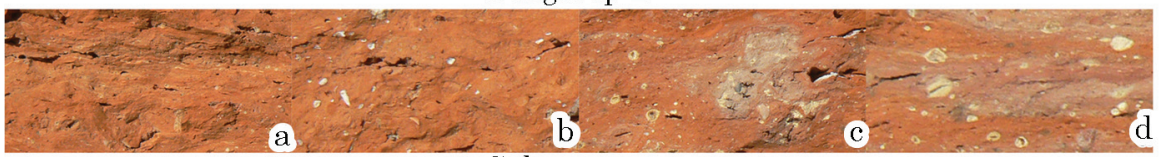

Subgroup 3

Fig. 2. Technological and morphological typology of medieval building ceramics (Flanged tiles) from the South-Western Crimea, groups and subgroups

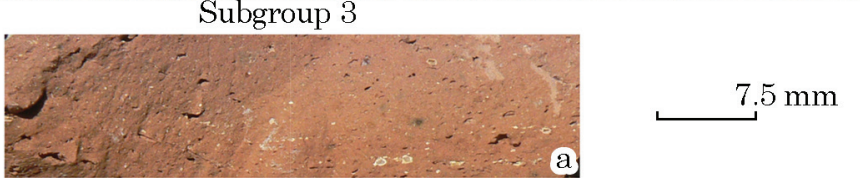

at least section of side flanges, form of lower cut and upper edge) — variant (individual unique forms, i. e. morphological spices: design and outline of individual details) ${ }^{1}$.

There are two methods of the dating of building ceramics. At first it is the stratigraphic context and general dating of layers by some groups of finds (amphorae, glazed ware, coins, etc.), which derive from the newest archaeological excavations. At second, it is morphological chronoindicators of building ceramics. They are consist of limited number of morphological features: «false top flange» ${ }^{2}$, up-

1. The definition of variants in compact notation is $\mathrm{X} /$ $\mathrm{Y} / \mathrm{Z}$, where $\mathrm{X}$ is number of the group, $\mathrm{Y}$ is number of the subgroup, $\mathrm{Z}$ is number of the variant.

2. «False top flange» in compact notation is FTF. per flange ${ }^{3}$, Flanged tiles without lower curves ${ }^{4}$. The dating of some of them has been published in special literature (Моисеев 2018b, с. 153-154). However, special substantiation of the chronology for other chronoindicators was made within this work. With no doubt it (chronology) is precursive and it has marked in the work by " $\left.{ }^{*}\right\rangle$.

$\boldsymbol{F T F}$ is represented on the upper edge of Flanged tiles in four variations: a cutting, a rim with height of $0.1-0.3 \mathrm{~cm}$, insignificant top flange, well-defined top flange and inconspicuous groove (fig. 6: I/1/15; 9: Ich/4/1; 10: II/1/6; 11: II/4/1, $\mathrm{II} / 4 / 3)$. This element is presented on Flanged tiles of TPC Bodrak, Ilyaz-Kaya, Ilka and Suatkan.

3. "Upper flange» in compact notation is UF.

4. "Lower curves» in compact notation is LC. 
Group Ich by A. I. Romanchuk's typology (I Chersonesos)

Subgroup 4

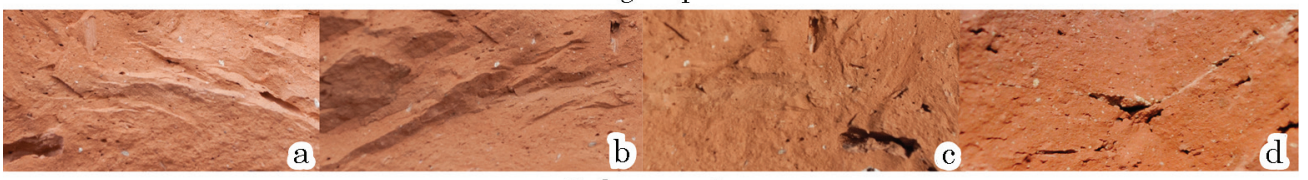

Subgroup 5

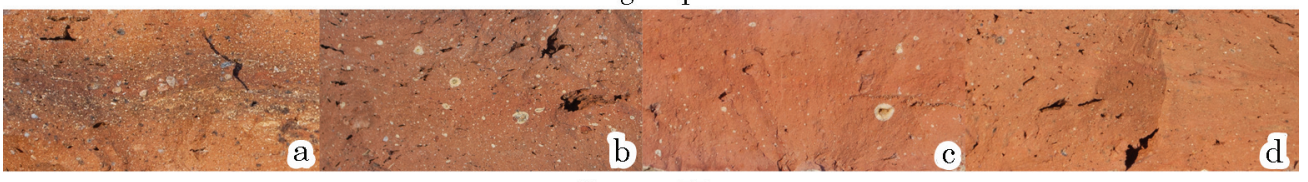

Group II

Subgroup 1

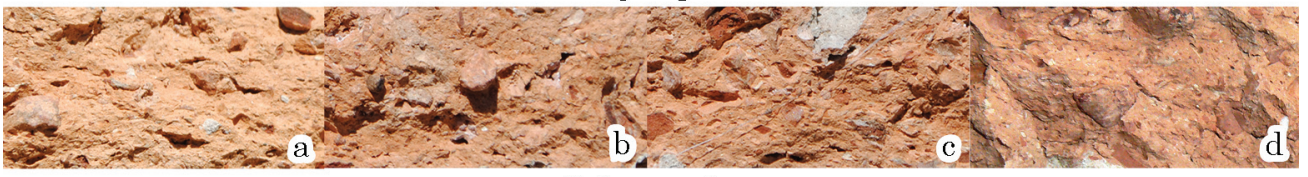

Subgroup 2

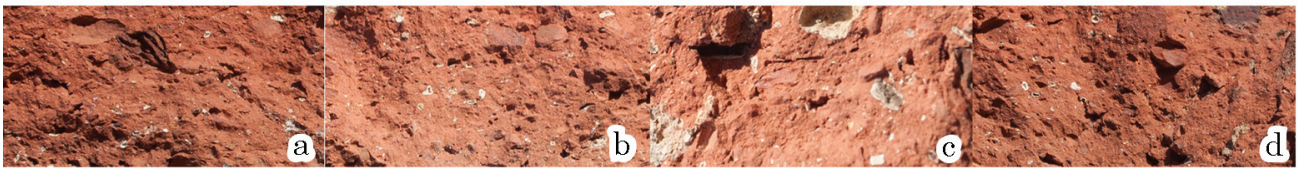

Subgroup 3

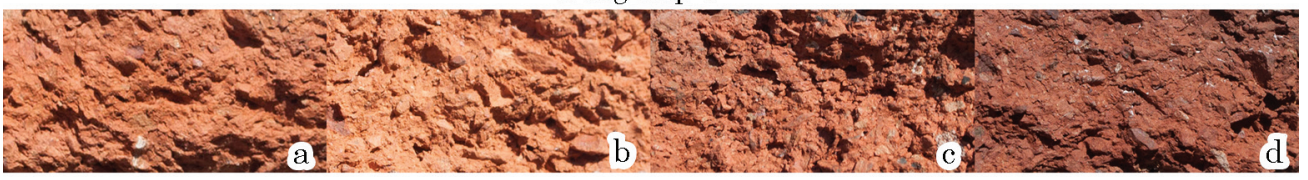

Subgroup 4

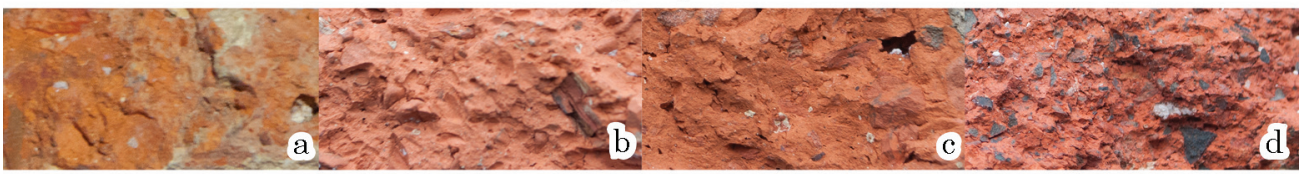

Subgroup 5

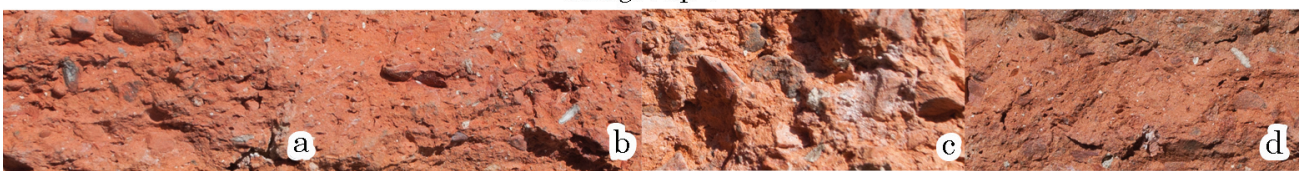

Subgroup 6

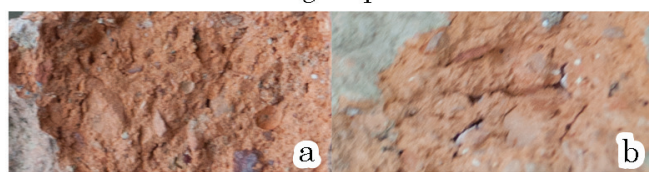

$7.5 \mathrm{~mm}$

Subgroup 7

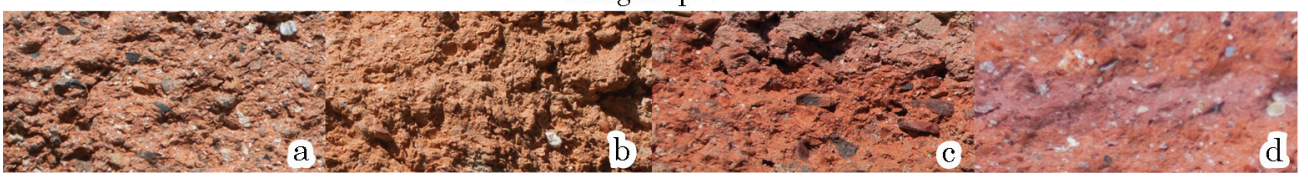

Fig. 3. Technological and morphological typology of medieval building ceramics (Flanged tiles) from the South-Western Crimea, groups and subgroups

The distribution of the element indicates that it is a universal chronological feature.

The dating of FTF bases on the complex of finds from excavations of the Right bank Tcimlyansk fortress ${ }^{1}$. There are Flanged tiles with clean top edge or FTF. The technology of flanged tile

1. «Right bank Tcimlyansk fortress» in compact notation is RBTF. production was brought to the Lower Don probably from the Crimea in the edge of the $700 \mathrm{~s} / 800 \mathrm{~s}$ (Калинина и др. 2014, с. 122-123, 126-127). Therefore, the technology of flanged tile production on the RBTF captures the development of the technology on one of the Crimean TPC in the edge of the $700 \mathrm{~s} / 800 \mathrm{~s}$. This date should be taken as a chronological point for Crimean material. 


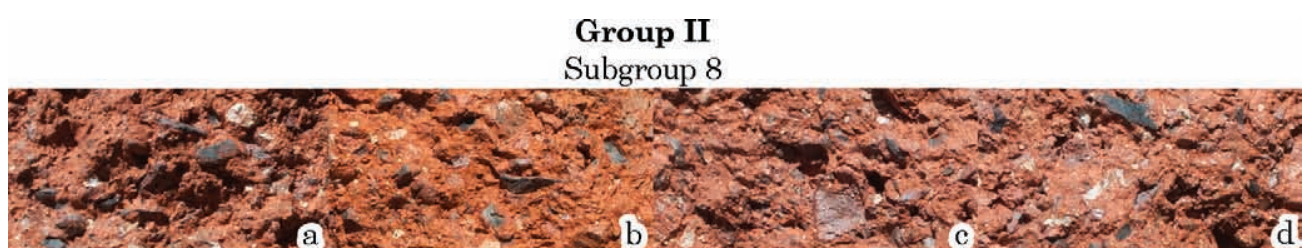

Subgroup 9

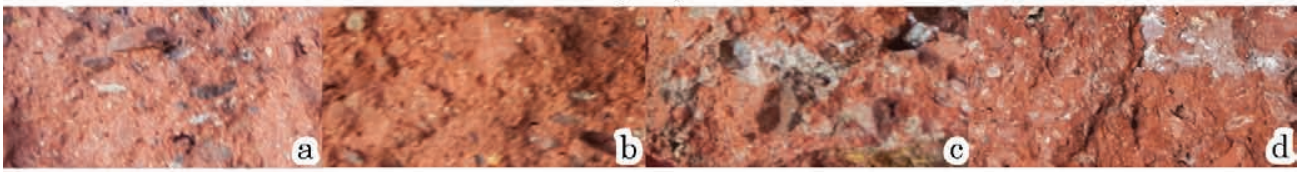

Subgroup 10

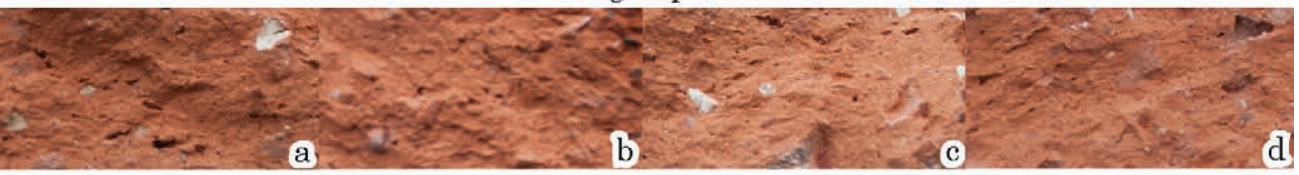

Subgroup 11
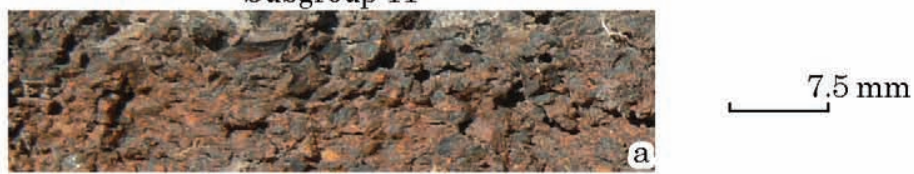

Subgroup 12

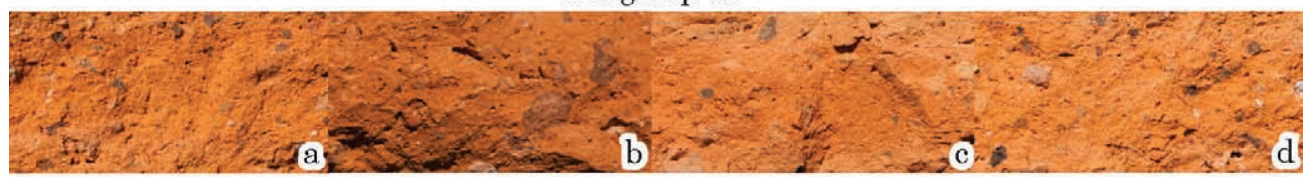

Group III

Subgroup 1

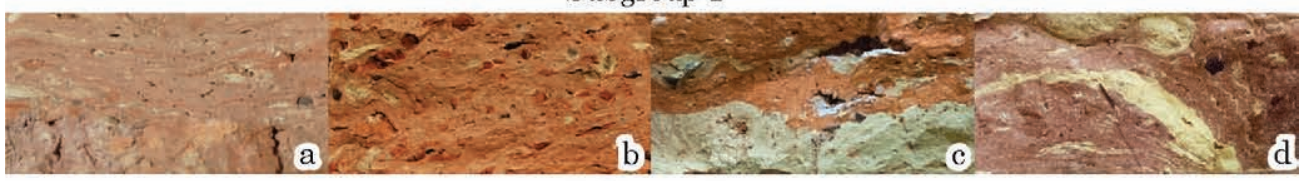

Subgroup 2

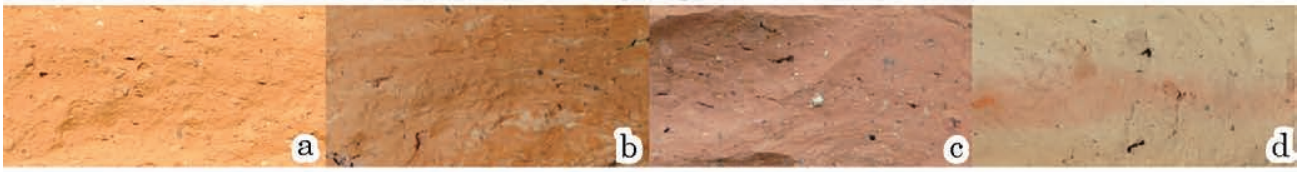

Subgroup 3

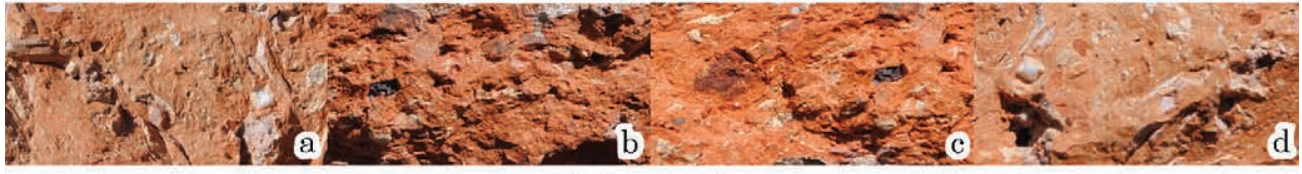

Subgroup 4

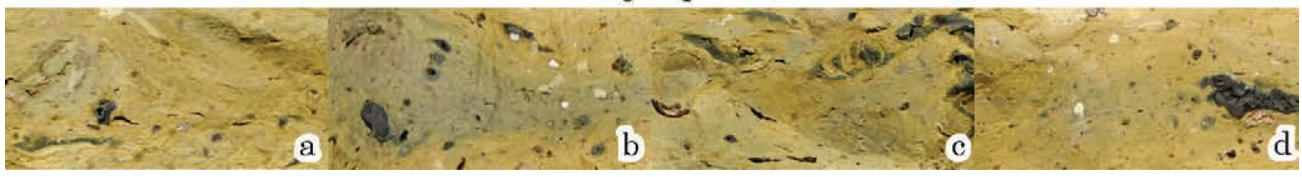

Fig. 4. Technological and morphological typology of medieval building ceramics (Flanged tiles) from the South-Western Crimea, groups and subgroups

$\boldsymbol{U F}$ (its appearance on flanged tiles) is another chronoindicator. Complexes from excavations of Chersonesos (onground temple on Devich'ya Hill, tomb 4) (Яшаева и др. 2018b, с. 123) and the temple on the Tuzlukh hill (Тесленко, Мусин 2015, с. 65, $73,89-93,136,268$, рис. 2.39-2.45) has central place in the dating of this process. According to them, 850s/860s-860s/880s Flanged tiles from closed assemblages have already had well-defined UF.
UF hasn't appeared immediately. There are transitional forms of it (FTF is still present on Flanged tiles): cross section wide cleat (II/4/3 fig. 11) and roll-shaped UF (II/1/7 — fig. 10). These "transitional» forms should be attributed to the earliest time of the technology - to the $850 \mathrm{~s}-860 \mathrm{~s}$. Likewise, bottom limit of the using transitional upper flange forms are the $840 \mathrm{~s}$ (Флёров 1995 , с. 486,488$)$, the time when RBTF 
Table 1. Correlation of typologies of medieval building ceramics

\begin{tabular}{|c|c|c|c|c|c|c|c|c|c|}
\hline \multicolumn{2}{|c|}{$\begin{array}{l}\text { The typology } \\
\text { of this work }\end{array}$} & \multicolumn{8}{|c|}{ Typologies of medieval building ceramics from the South-Western Crimea in historiography } \\
\hline 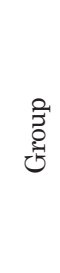 & 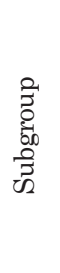 & 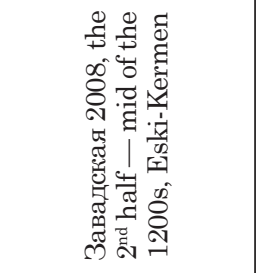 & 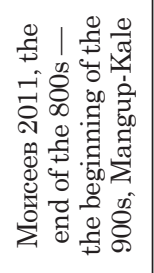 & 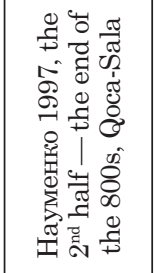 & 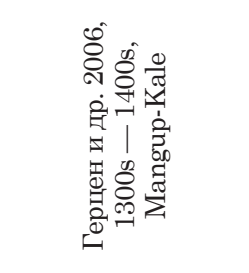 & 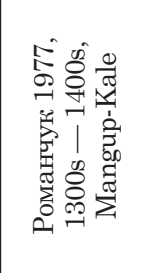 & 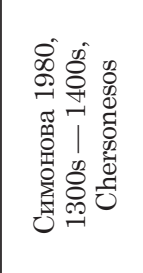 & 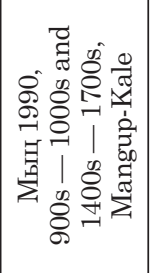 & 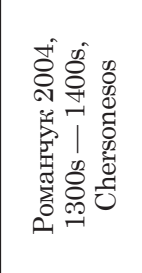 \\
\hline \multirow[t]{7}{*}{$\mathrm{I}$} & - & Group Іб & - & - & $\begin{array}{l}\text { Red-paste roof } \\
\text { tile with engobe, }\end{array}$ & & & & $C_{n}$ \\
\hline & 1 & - & Group I & Group I & - & - & - & - & - \\
\hline & 2 & - & - & - & - & - & - & - & - \\
\hline & 3 & Group Ia & - & - & - & - & - & Group III & - \\
\hline & 4 & - & - & - & - & - & Group IV & - & - \\
\hline & 5 & Group II & - & - & - & Group II & - & - & - \\
\hline & 6 & - & - & - & - & - & - & Group IV & - \\
\hline Ich & - & $\begin{array}{l}\text { Group of the cher- } \\
\text { sonesos paste }\end{array}$ & - & - & - & - & Group I & - & Group I \\
\hline \multirow[t]{4}{*}{ II } & - & - & Group II & Group II & - & Group I & Group II & Group I & Group II \\
\hline & 1 & - & - & - & - & - & - & - & - \\
\hline & 2 & Group III & - & - & - & - & - & - & - \\
\hline & 3 & Group IV & - & - & - & - & - & - & - \\
\hline \multirow[t]{3}{*}{ III } & - & - & Group III & Group III & - & - & - & - & - \\
\hline & 1 & - & - & - & - & - & - & - & - \\
\hline & 2 & - & - & - & - & Group III & - & Group III & - \\
\hline
\end{tabular}

has been destructed and where are not any forms of UF on its Flanged tiles (Калинина и др. 2014, c. $120-123)$.

Flanged tiles without LC. The beginning of the transition to the manufacture of Flanged tiles without LC was initiated no later than the mid900s. The basis for the dating is complex from excavations of the temple on the Unnamed cape (Яшаева 2005, с. 484-485). It has Flanged tiles with poorly defined (transitional) LC and they got into the roof as a late repair (Моисеев 2018b, c. 153). The time of active using of this technology falls on the mid-900s-beginning of the 1100s. The chronology bases on two complexes: floors with Flanged tiles without LC from rooms 5 and 6 near the curtain XVII (Романчук 2004, с. 85) and the building phase of XLV block (Klenina et al. 2018, p. 154) in Chersonesos. The end of the manufacture of Flanged tiles without LC should be attributed to the time no later than the mid1200s (Klenina et al. 2018, p. 155-156).

The typology of medieval flanged tiles of the South-Western Crimea.

Group I: TPC Ilka. The paste is compact, well mixed, apparently made of clay from early Cretaceous deposits. Finished tiles are of various hues of red. The paste contains lime, lime gravel, chamotte, particles of ferrous compounds and ar- gillite. The surface may be coated with engobe of the same color as the tiles or in various shades of yellow.

TPC that was producing the group I situates on the northeastern slope of Ilka mountain, in the col of Bajrachtan-Jer (water-parting between the Adym-Chokrak and Belbek valleys) (fig. 1). Archaeological geomagnetic exploration localized more than 20 kilns on the territory of TPC Ilka - four of them were excavated (Науменко и др. 2013, с. 67).

Subgroup 1 (fig. 2). The paste is compact, well mixed, apparently made of clay from early Cretaceous deposits. Finished tiles are red (10R6/6; $2.5 \mathrm{YR} 6 / 4 ; \quad 2.5 \mathrm{YR} 6 / 6 ;$ 5YR6/4; 5YR6/6) ${ }^{1}$. The paste contains lime, lime grus, chamotte from red colored or black ceramic, particles of ferrous compounds. The surface coats with engobe of the same color as the tiles or red color.

I/1 has dated back to the edge of the $700 \mathrm{~s} / 800 \mathrm{~s}-$ 900s (maybe also 700s*) by many identified fragments and archaeological full forms ${ }^{2}$ from excavations of Chersonesos, Eski-Kermen, Mangup,

1. Numbers of colors are made by the soil chart Munsell (Color Munsell 1996).

2. "Archaeological full forms" in compact notation is "AFF». 
Pampuk-Kaya, TPC Ilka, settlements Baga, Markur, Varnutka Simeiz, Upper Oreanda (supplement; tabl. 2) and analogies from RBTF. Flanged tiles. The soubgroup has 5 classes (supplement) and 16 variants (fig. 6; supplement). Class 1 (variants 1, 6, 8-9, 15-16- fig. 6; supplement; tabl. 2) was found during excavations of Chersonesos, Mangup, settlements Baga and Varnutka, Simeiz, TPC Ilka, Upper Oreanda (supplement). Class is the earliest due to FTF. So, it can be determined* by the time of $1^{\text {st }}$ half of the $800 \mathrm{~s}$ and, possibly, earlier time. Class 2 (variants 10 11 - fig. 6; supplement; tabl. 2) was found during excavations of Mangup and the settlement Baga (supplement). The class doesn't have UF, that is a marker of late time. However, LC of the class are similar to class 4 , which already has UF. We can assume, that class 2 belongs to later time, than class 1 . Class 3 (variant 7 - fig. 6; supplement; tabl. 2) was found during excavations of TPC Ilka (supplement). Transitional form of UF shows, that the production of classes 1 and 2 has already stopped and class 4 has not yet begun. Therefore, class 3 belongs* to the $850-860$ s. Class 4 (variants 2-5, 13, 17 - fig. 6; supplement; tabl. 2) was found during excavations of Chersonesos, Eski-Kermen, Mangup, Pampuk-Kaya, TPC Ilka and settlement Markur (supplement). Flanged tiles of the class have well-formed UF, belongs to final stage of the life of the settlement in Lagernaya Gully in Mangup (Моисеев 2011, с. 174, $176,180,182$, рис. 2). Moreover, I/1/17 exists in complexes of 880s in Chersonesos (Яшаева и др. 2018b, c. 123). Class 4 cannot be later than the $950 \mathrm{~s}$, when the process of degradation of LC has begun. Therefore, class belongs* to the $2^{\text {nd }}$ half of the $800 \mathrm{~s}-1^{\text {st }}$ half of the $900 \mathrm{~s}$. Class 5 (variant 12 - fig. 6; supplement; tabl. 2) was found during excavations of Mangup (supplement). Class is the earliest due to FTF and belongs* to the $700 \mathrm{~s}-1^{\text {st }}$ half of the $800 \mathrm{~s}$.

Subgroup 2 (fig. 2). The paste is compact, well mixed, apparently made of clay from early Cretaceous deposits. Finished tiles are red

Table 2. Chronology of groups I, Ich

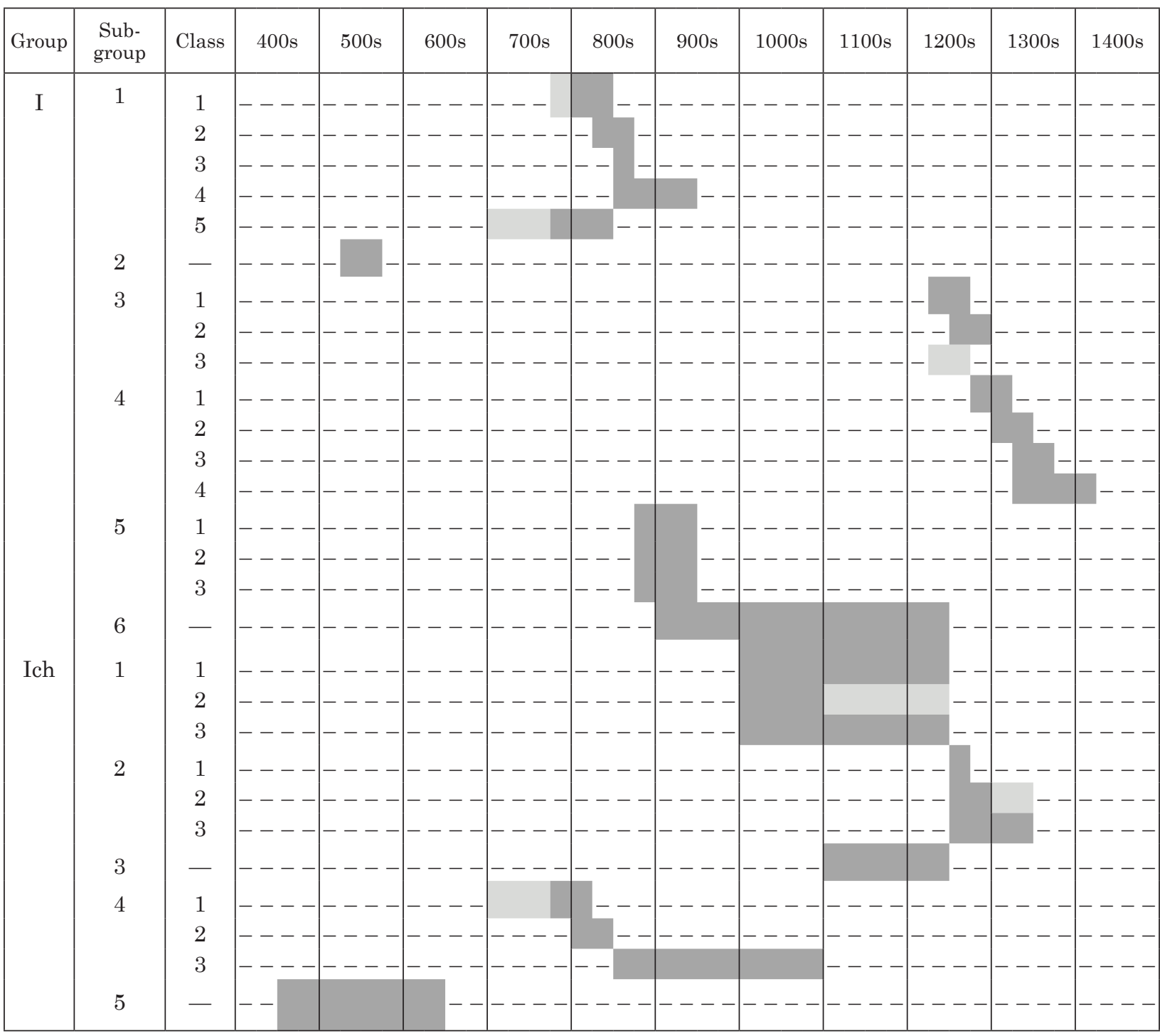



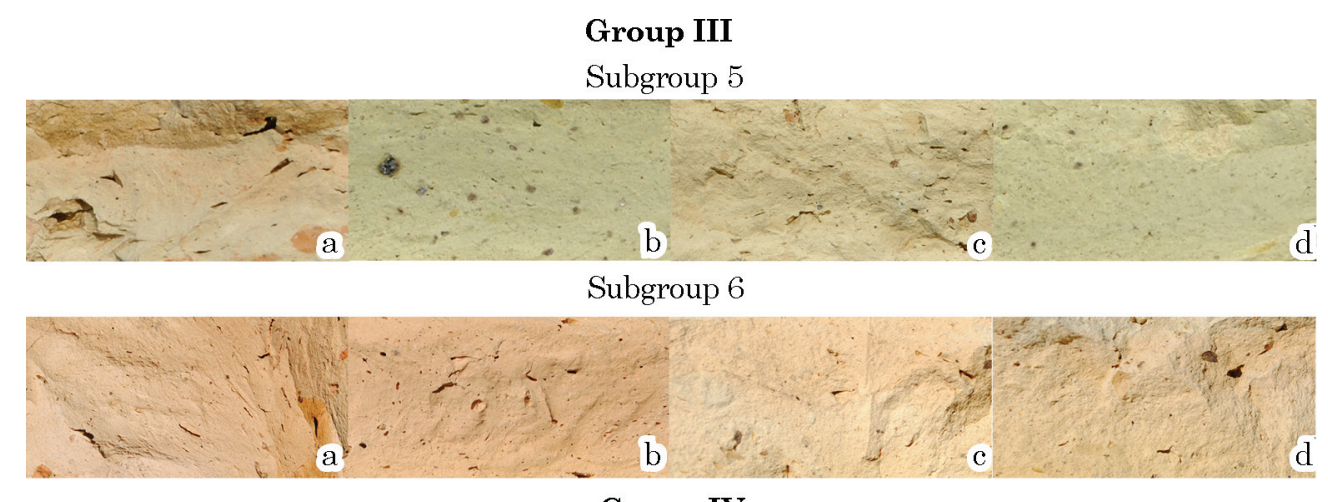

Group IV

Subgroup 1

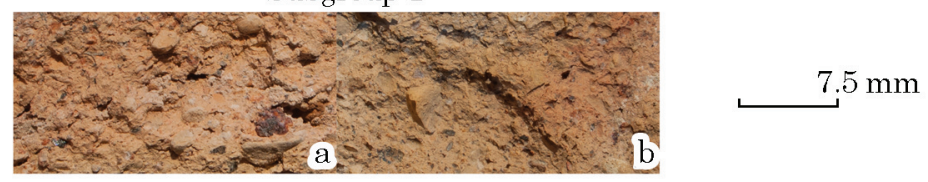

Subgroup 2

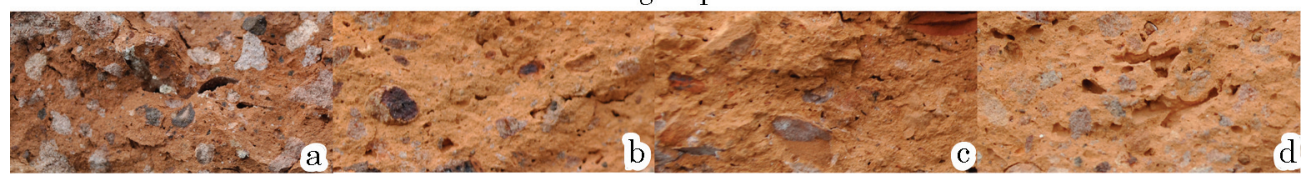

Subgroup 3

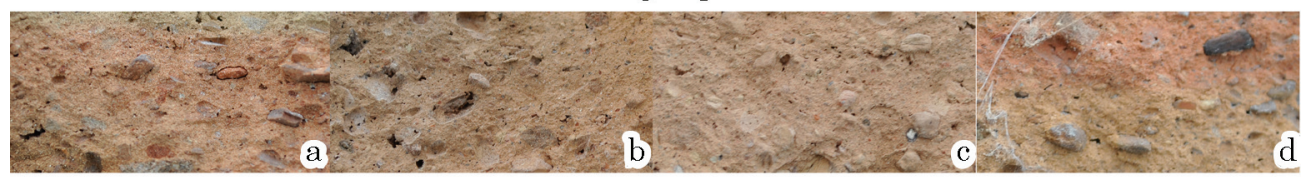

Group V

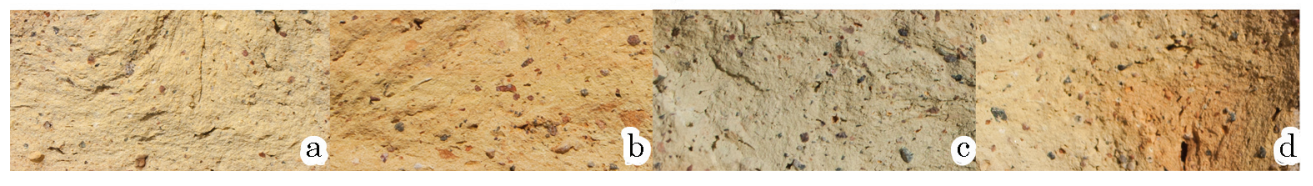

Fig. 5. Technological and morphological typology of medieval building ceramics (Flanged tiles) from the South-Western Crimea, groups and subgroups

(5YR7/8; 7.5YR7/4). The paste contains lime and huge particles of ferrous compounds (0.5$2.0 \mathrm{~cm})$.

Roof tiles of the subgroup were found during excavations of defense wall A-XIX in Mangup (Demir-Kapu cleft), layers of building the fortress on Mangup plateau in the middle of the $500 \mathrm{~s}$ (Герцен, Манаев 2005, с. 322-325, 328-330, 344). Moreover, it was found during excavations of the 1200s kiln on TPC Ilka (Моисеев 2013, c. $33-34 ; 2014 \mathrm{a}$, c. 284). Finds from Mangup determine the chronology of the subgroup in the middle of the 500s (tabl. 2). The condition of the finds doesn't allow to divide it into classes.

Subgroup 3 (fig. 2). The paste is compact, well mixed, apparently made of clay from early Cretaceous deposits. Finished tiles are red (5YR7/6; 5YR6/6; 7.5YR7/4). The paste contains lime (large number of small nodules or their concentrated accumulations are on the chip of the tile) and particles of ferrous compounds. The surface is coated with engobe of light-yellow color (2.5YR8/2).

$\mathrm{I} / 3$ is dated back to the $2^{\text {nd }}$ half of the $1200 \mathrm{~s}$ (Моисеев 2014b, с. 286-287; Klenina et al.
2018, p. 159) and was made by TPC Ilka (fig. 1; tabl. 2) in kilns 3 and 10, which were archaeologically investigated (Моисеев 2014a, с. 279-278, 284, 300-302, рис. 2-4; Терещенко и др. 2020, c. 114-115; Moisieiev 2018, p. 259-262). Flanged tiles. The subgroup has 3 classes (supplement) and 54 variants (fig. 6-7; supplement). Class 1 (variants 3-7, 9-10, 12-13, 17-20, 22, 2425, 29, 32-39, 43-45, 50-51 - fig. 6-7; supplement; tabl. 2) was found during excavations of Chersonesos, Eski-Kermen, Isar-Kaya, Mangup and TPC Ilka (supplement). The class has been dated by finds from excavations of the block in the central part of Eski-Kermen (Завадская 2008 , с. 294). The mass origin of it from destruction layers of the end of the 1200s indicates that tiles were produced during the great rebuilding of the block in the mid-1200s. Class 2 (variants $2,8,11,15-16,23,26,40,42,46-47,53-$ fig. 6-7; supplement; tabl. 2) was found during excavations of Chersonesos, Eski-Kermen and TPC Ilka (supplement). Its chronology is related to the dating of classes 1 and 3 . It takes middle position by morphological features (supple- 
ment) ${ }^{1}$ between them and belongs to the $2^{\text {nd }}$ half of the 1200s. Class 3 (variants 1, 14, 27, $30-$ fig. 6-7; supplement; tabl. 2) was found during excavations of Chersonesos, Eski-Kermen and TPC Ilka (supplement). The class is the earliest with archaic drained roll.

Subgroup 4 (fig. 2). The paste is compact, well mixed, apparently made of clay from early Cretaceous deposits. Finished tiles are red (5YR7/6; $5 Y R 6 / 6 ; 7.5 Y R 7 / 4)$. The paste contains natural sand, which often concentrates in spherical accumulations. The surface is coated with engobe of the same color as the tiles, but sometimes it can be lighter (2.5YR8/2) than a chip of the tile.

The production of I/4 (tabl. 2) started at the end of the 1200s (Klenina et al. 2018, p. 159; Моисеев 2014b, c. 287) and stopped not earlier than 1462 early 1470s (Моисеев и др. 2019, с. 40, 48). Flanged tiles. The subgroup has 4 classes (supplement) and 22 variants (fig. 7-8; supplement). Class 1 (variants 1, 6-7, 13, 16-20- fig. 7-8; supplement; tabl. 2) was found during excavations of Eski-Kermen, Mangup and TPC Ilka (supplement). It has been dated back by some variants from Eski-Kermen by the edge of the 1200s 1300s (Моисеев 2014b, с. 287). Class 2 (variants 3-5, 21 - fig. 7-8; supplement; tabl. 2) was found during excavations of Chersonesos, EskiKermen, Mangup, settlement Varnutka and TPC Ilka (supplement). It has been dated back to the $1^{\text {st }}$ half of the 1300s (Klenina et al. 2018, p. 159). Class 3 (variants 2, 9-10, 14 - fig. 7; supplement; tabl. 2) was found during excavations of Eski-Kermen, Mangup ${ }^{2}$, settlement Varnutka and TPC Ilka (supplement). Its chronology is related to the dating of classes 2 and 4 . Class 3 takes middle position between them due to its morphological features (supplement) ${ }^{3}$ and belongs to the middle of the 1300s. Class 4 (variants 8, 11-12, 15 - fig. 7; supplement; tabl. 2) was found during excavations of Eski-Kermen, Mangup and TPC Ilka (supplement). I/4/15 formed a large group of AFF and fragments in destroyed roof of the temple of TPC Ilka and it can be defined as one of huge «repairs» ${ }^{4}$ (Моисеев 2014b, с. 290-291, 299-300, табл. 5). It was the latest during the last building period of the temple at the end of $1300 \mathrm{~s}-1^{\text {st }}$ half of the 1400s. (Моисеев 2014b, с. 279).

1. Class 1 , that is late one, has bad defined transition from side flange to the field of a flanged tile. Class 3, that is the earliest, has archaic drained roll.

2 . The handicraft mark $\mathrm{I} / 4 / 2$ (class 1 ) is very similar to the mark $\mathrm{I} / 4 / 1$ (class 1 ). Therefore, it is easy to confuse them in the works of A. L. Jacobson and other researchers. Thus, it isn't known for sure, which variant and class it is (Мыц 1990, c. 230 рис. 6: 33, 34; Тиханова 1953, с. 431, рис. 1: 46; Якобсон 1979, с. 101 , рис. 63: 76-82).

3. Class 3 has transitional form of a side flange from high one (class 2) to low one (class 4).

4. I/4/15 in the publication of the complex was misinterpreted as a "first set» of the roof tiles, which were used during the building.
The class ${ }^{5}$ was found on the esplanade of the Citadel of Mangup ${ }^{6}$ (Моисеев 2014b, с. 288) and is dated by the time no later than the 1420s (Мыц 2009 , c. 134). I/4/15 was found during excavations of Eski-Kermen in 1936-1937 (Моисеев 2018 a, с. $190,168-169$, рис. 15,15$)$ which was abandoned in the $1^{\text {st }}$ half of the 1300s (Айбабин, Хайрединова 2011, с. 429; Тесленко 2020, c. 252). Therefore, class dates by the time of the mid-1300s - $1^{\text {st }}$ quarter of the 1400 s.

Subgroup 5 (fig. 2). The paste is compact, well mixed, apparently made of clay from early Cretaceous deposits. Finished tiles are red (2.5YR6/8). The paste contains big and medium particles of red and black chamotte. The surface is coated with engobe of the same color as the tiles (5YR7/6).

Lower chronological limit of the production of $\mathrm{I} / 5^{7}$ is connected to the time of formation of tile collapsing in Lagernaya Gully on Mangup in the end of the $800 \mathrm{~s}$ - beginning of the $900 \mathrm{~s}^{8}$ (Моисеев 2011, с. 177). The upper limit* of the production of $\mathrm{I} / 5$ is the mid-900s because some variants (I/5/1, I/5/10) have poorly defined (transitional) LC form (tabl. 2). Flanged tiles. The subgroup has 3 classes (supplement) and 16 variants ${ }^{9}$ (fig. 8; supplement). Class 1 (variants 4, 6-7, 9, $11-13,15$ - fig. 8; supplement) was found during excavations of Chersonesos, Eski-Kermen and settlement Varnutka (supplement). Class 2 (variants 1, 3 and 5- fig. 8; supplement) was found during excavations of Eski-Kermen and TPC Ilka (supplement). Class 3 (variant 10 - fig. 8; supplement) was found during excavations of EskiKermen (supplement).

Subgroup 6 (fig. 1). The paste is compact, well mixed, apparently made of clay from early Cretaceous deposits. Finished tiles are of various hues of red (5YR6/6; 2.5YR6/8; 2.5YR6/6; 2.5YR5/8; $5 \mathrm{YR} 6 / 8)$. The paste contains a lot of lime, lime and quartz gravel, particles of ferrous compounds and argillite $(0.02-0.5 \mathrm{~cm})$ and small particles of another black mineral. The surface is coated with engobe of the same color as the tiles.

The subgroup was found during excavations of Eski-Kermen (supplement; tabl. 2). Presumably, the chronological location of I/6 is between the 900s - mid-1200s (Моисеев 2018a, с. 169) and need redefining.

\section{5. $\mathrm{I} / 4 / 8, \mathrm{I} / 4 / 15$.}

6. Unfortunately, the complex of the Citadel of Mangup hasn't been yet completely published: there are only statistics and the definition of some variants (Моисеев 2014b, с. 288).

7. There are no tiles of $I / 5$ in the publication of the complex. Nevertheless, the methodology demands to make chipping and photo fixation of all groups and subgroups of tiles, which were defined in the complex. After some time I/5 was found in this data.

8. The number of I/5 pieces was low. Therefore, we can say, that they had been brought to the roof in the end of its existing.

9. I/5/2, I/5/8, I/5/14, I/5/16 have no defined classes. 


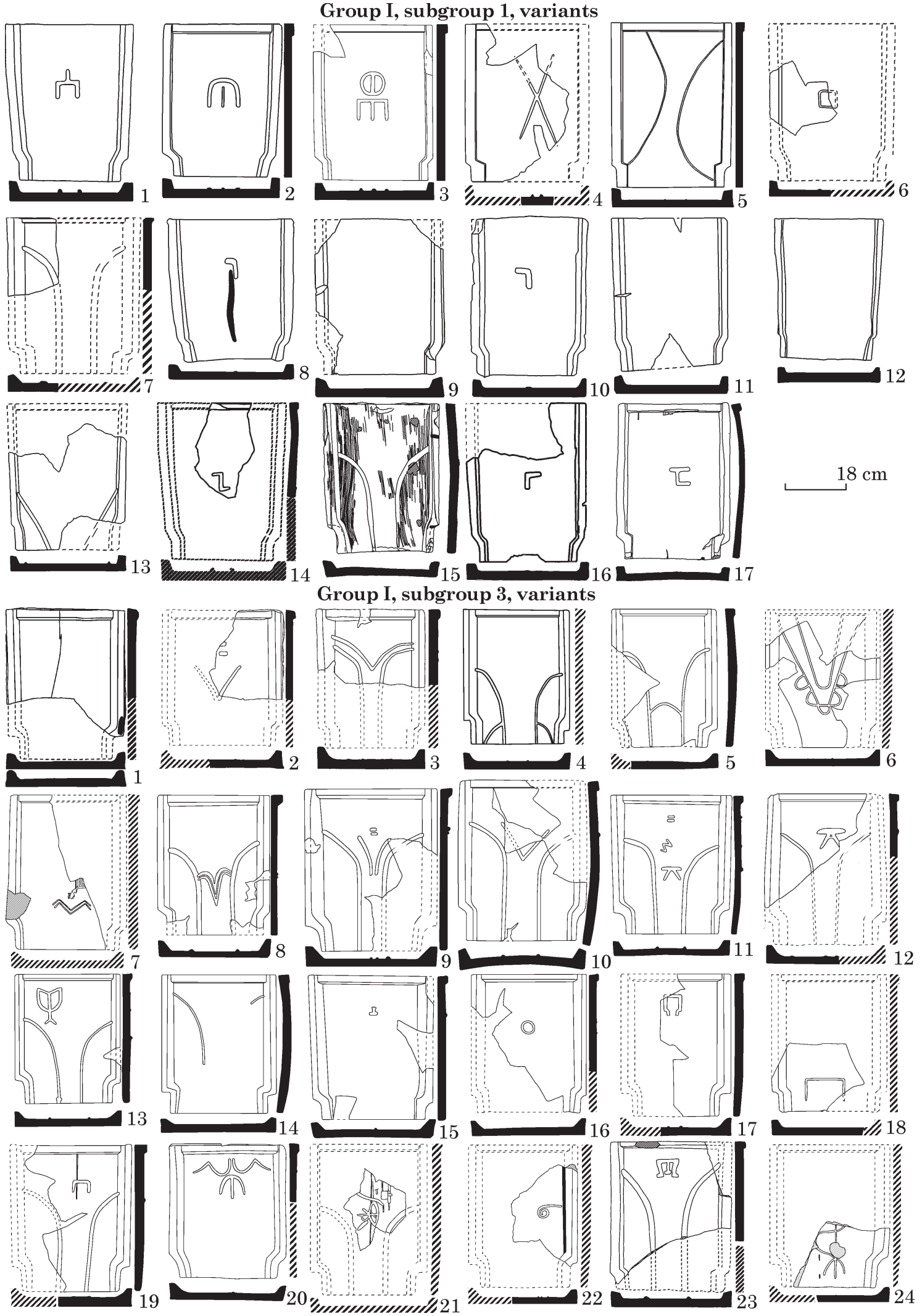

Fig. 6. Technological and morphological typology of medieval building ceramics (Flanged tiles) from the South-Western Crimea, variants 


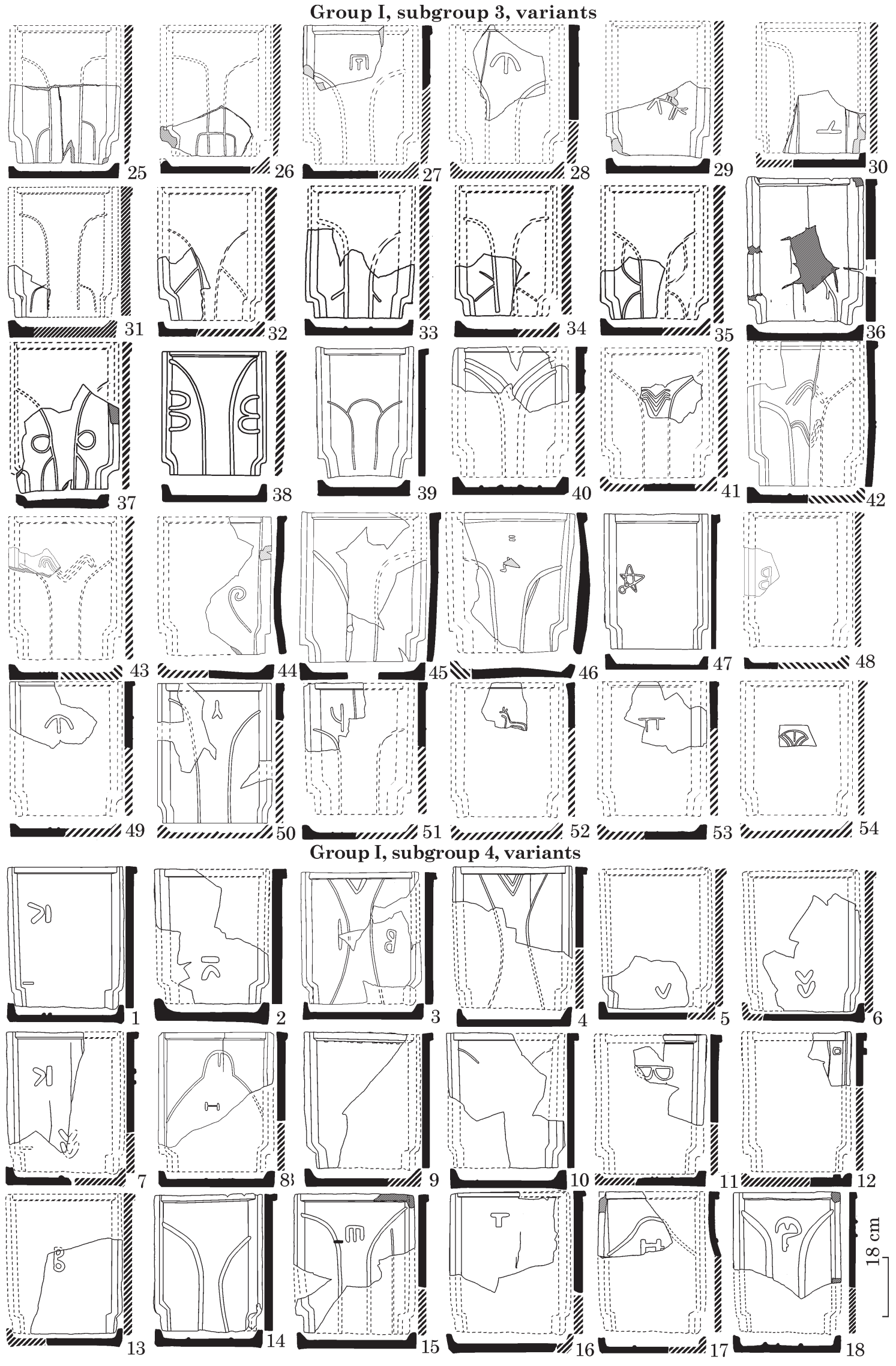

Fig. 7. Technological and morphological typology of medieval building ceramics (Flanged tiles) from the South-Western Crimea, variants 


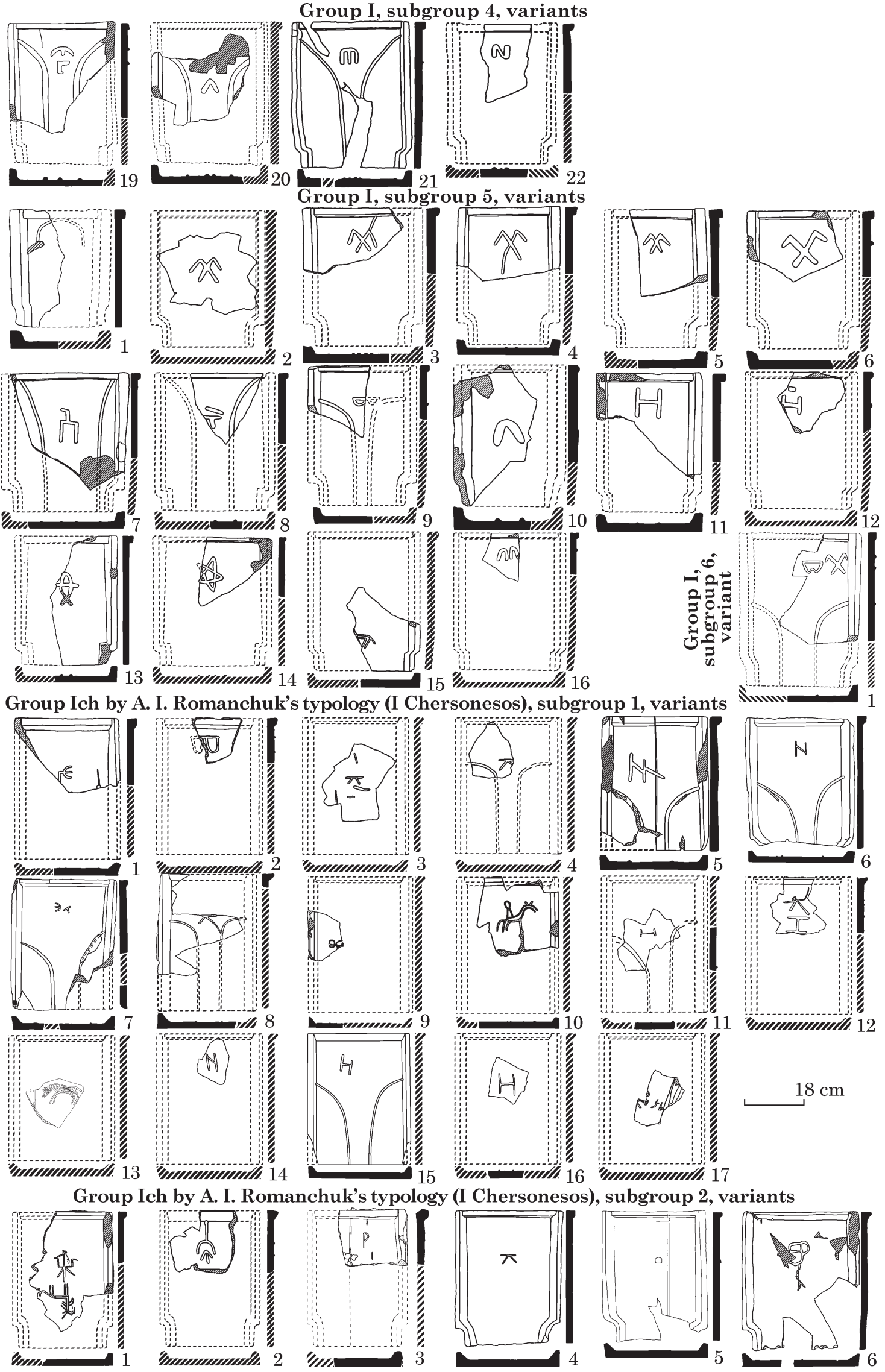

Fig. 8. Technological and morphological typology of medieval building ceramics (Flanged tiles) from the South-Western Crimea, variants 


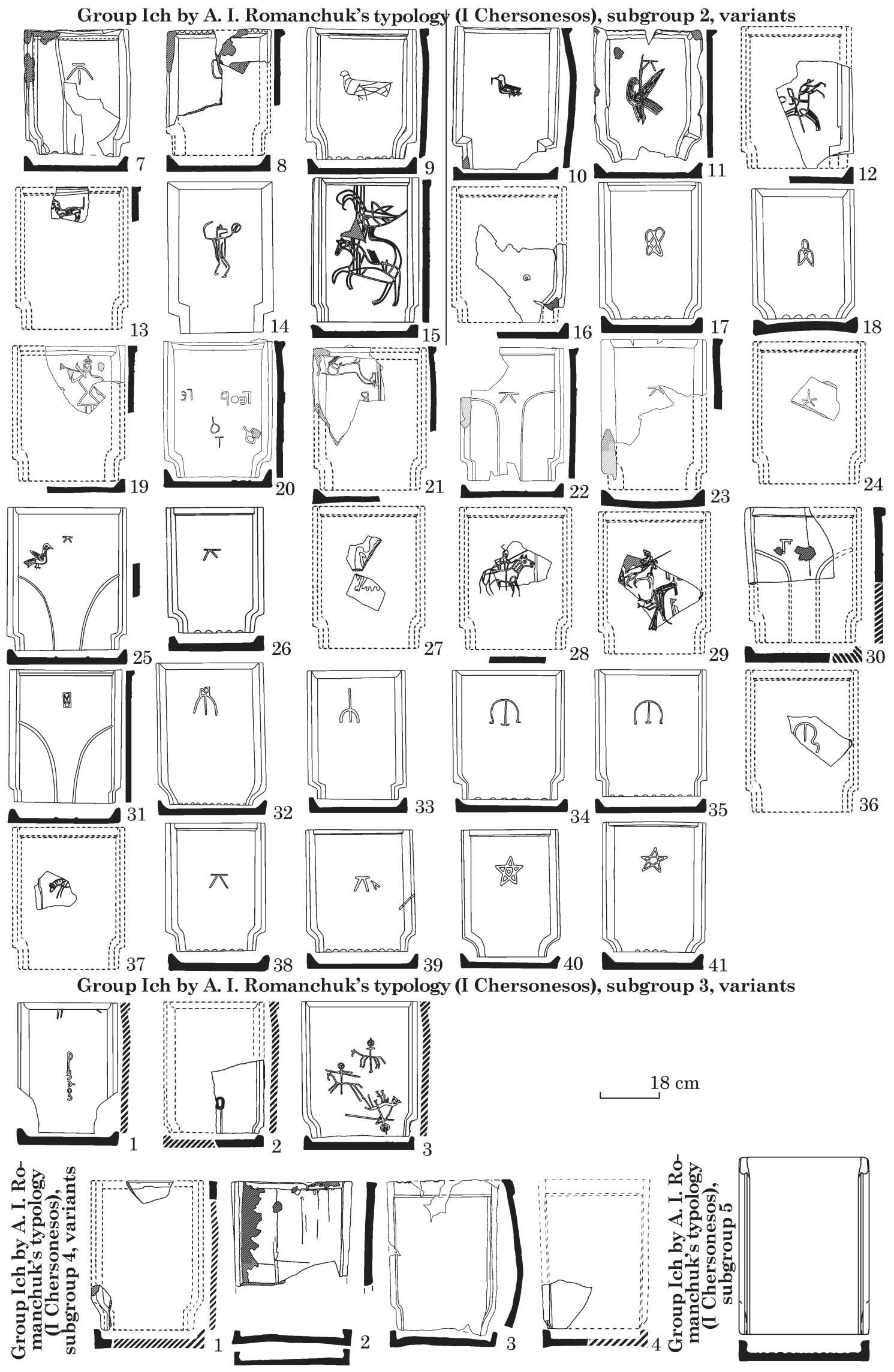

Fig. 9. Technological and morphological typology of medieval building ceramics (Flanged tiles) from the South-Western Crimea, variants 


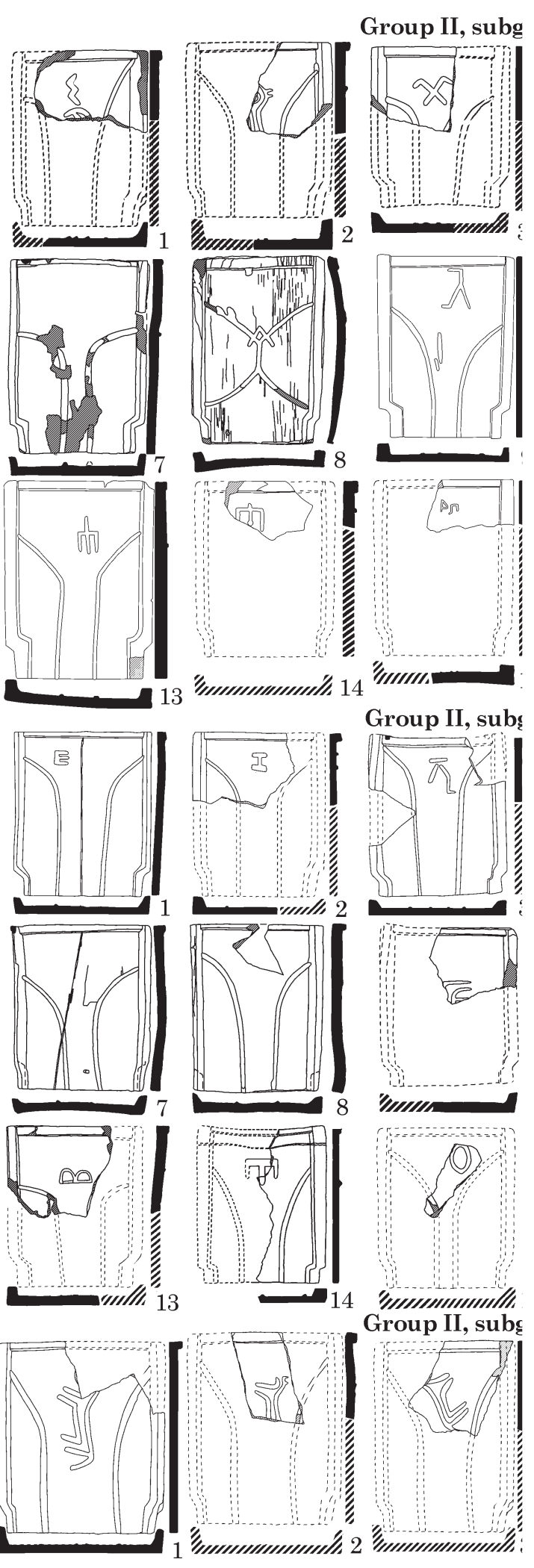

Fig. 10. Technological and morphological typolog the South-Western Crimea, variants
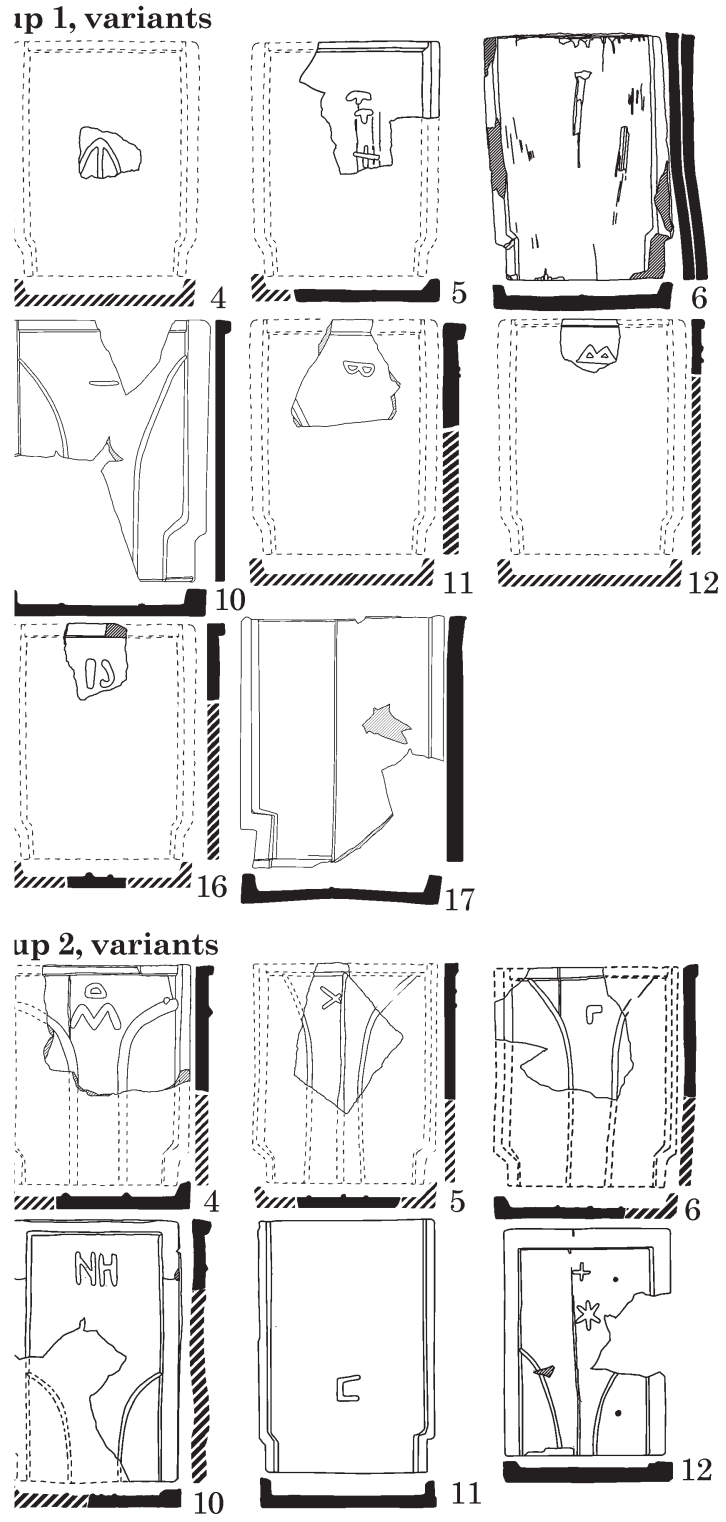

$18 \mathrm{~cm}$
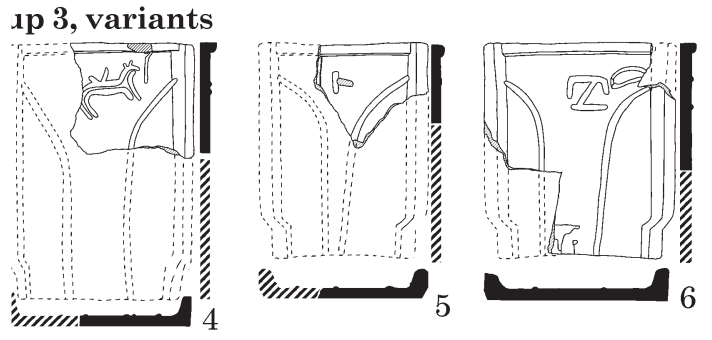

E medieval building ceramics (Flanged tiles) from 


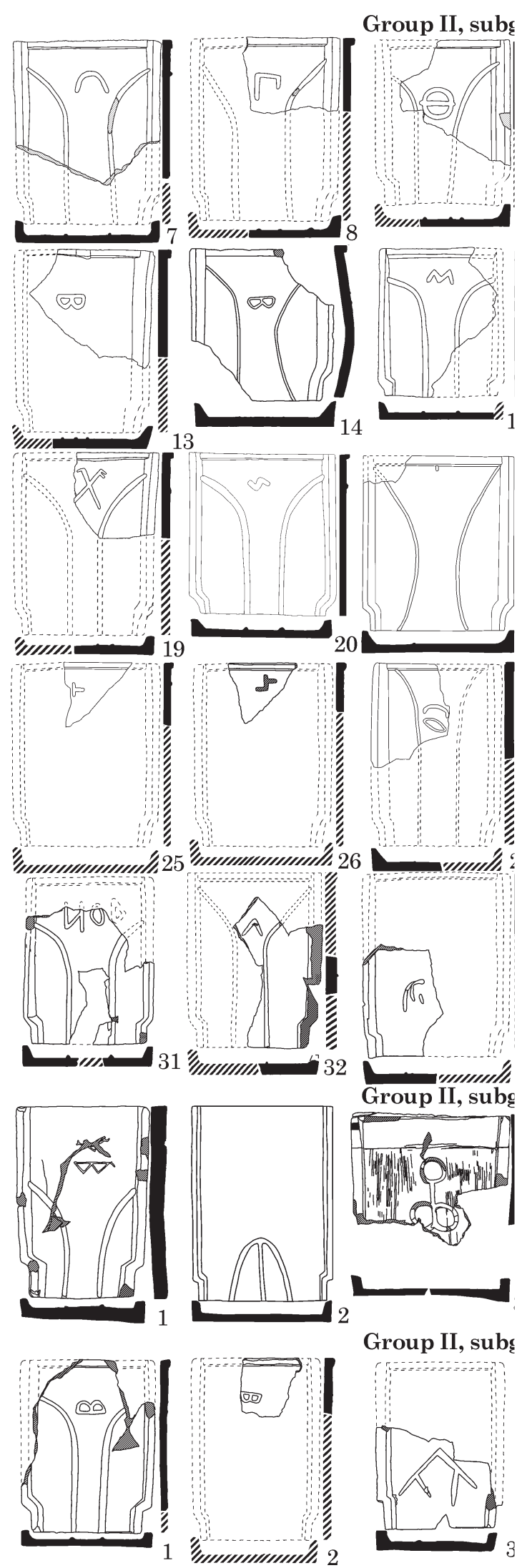

Fig. 11. Technological and morphological typolog the South-Western Crimea, variants

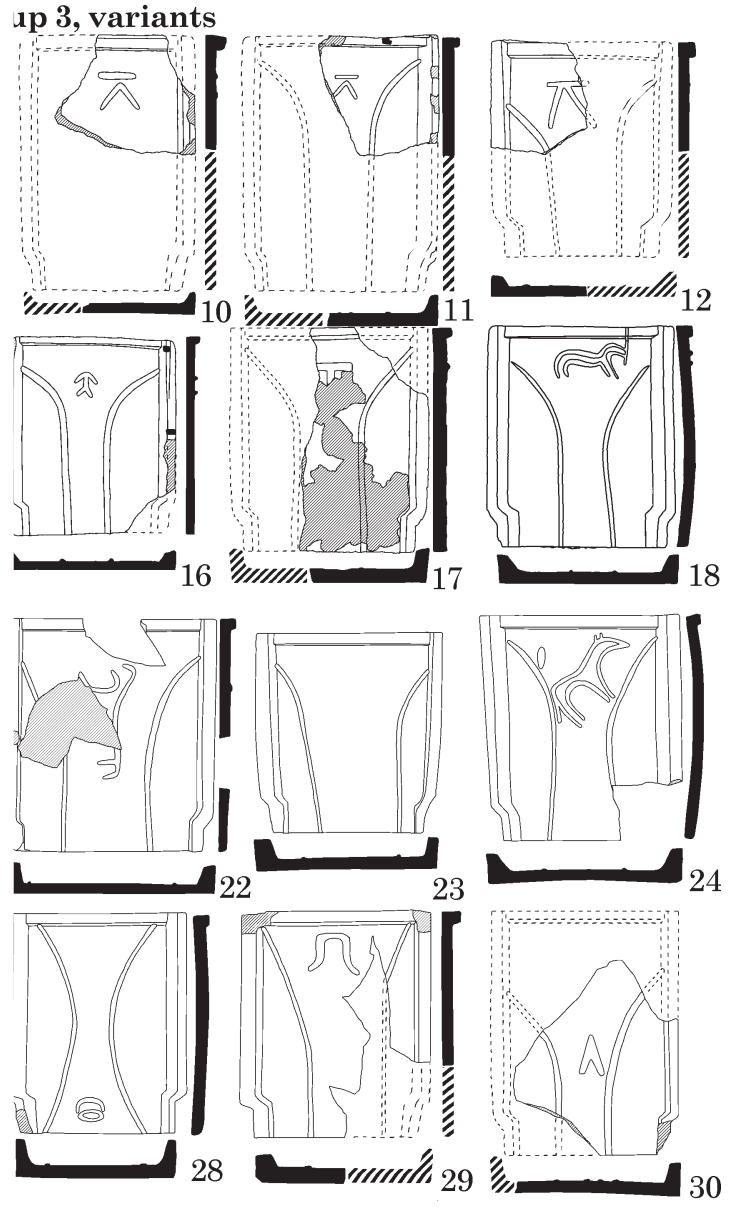

$8 \mathrm{~cm}$
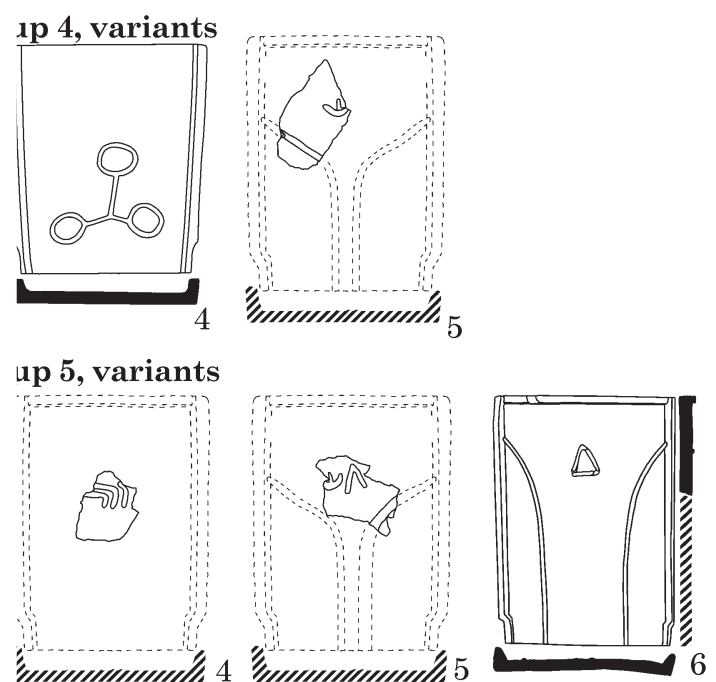

?medieval building ceramics (Flanged tiles) from 


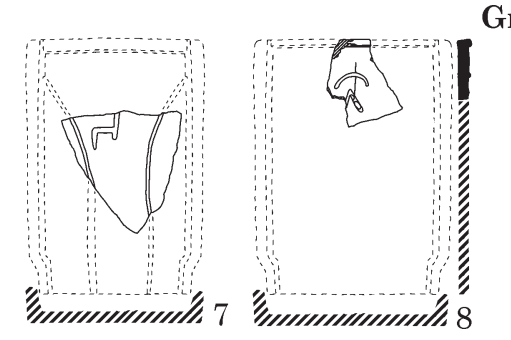

Group II, subgroup 5, variants
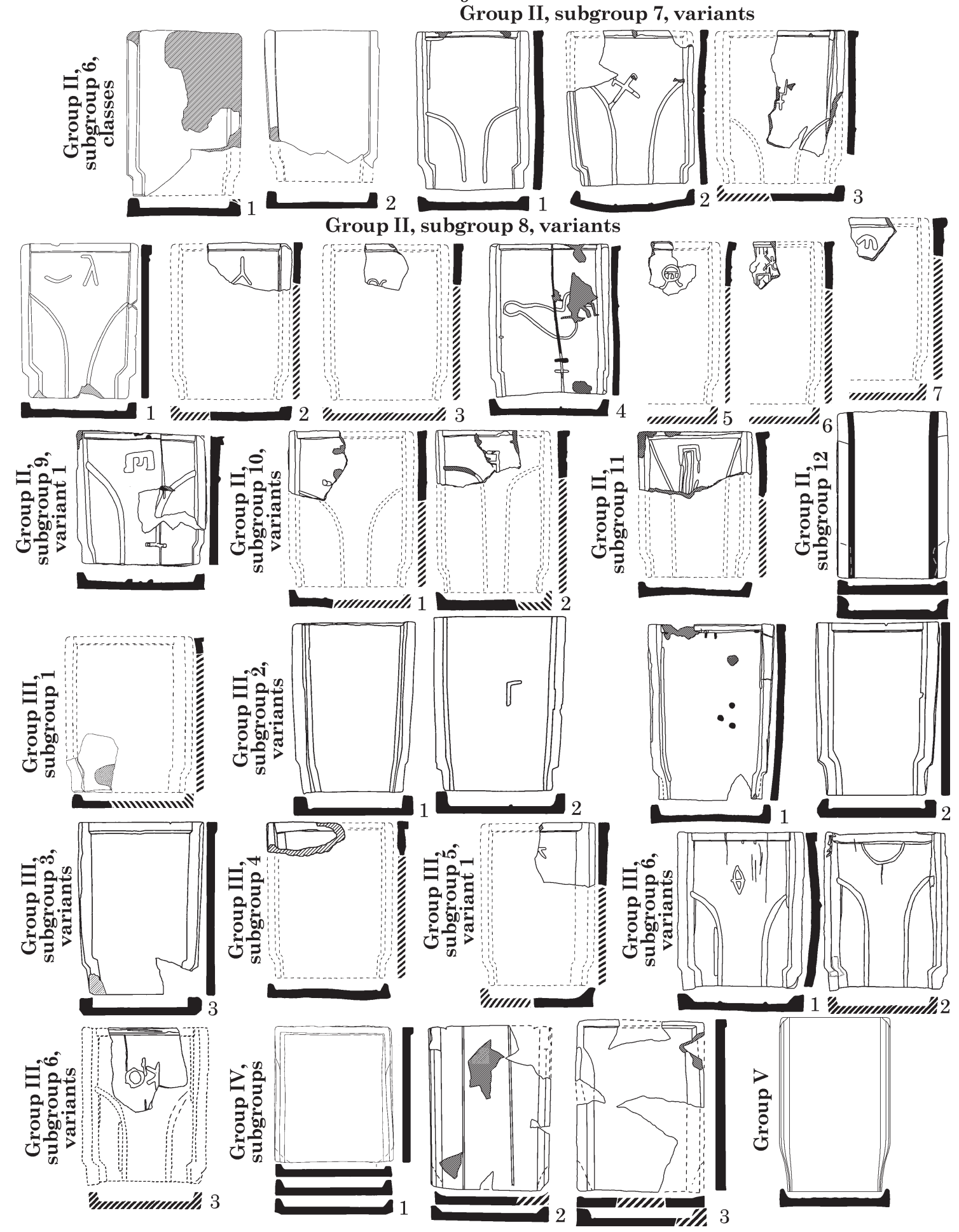

Fig. 12. Technological and morphological typology of medieval building ceramics (Flanged tiles) from the South-Western Crimea, variants 
Group Ich: tile production center Chersonesos $^{1}$. The paste is compact, well mixed, apparently made of clay from Miocene deposits. Finished tiles are red. The paste contains an admixture of lime. The surface is coated with lightyellow engobe.

Kilns that were producing such tiles were excavated on the north side of the Akhtiar bay ${ }^{2}$ (the 800s) (Паршина та ін. 2001, с. 69-70; Рыжова 1982, c. 149-151), in Chersonesos (the 1000s1100s (Якобсон, 1950, с. 154-155) and the end of the 1100s - beginning of the 1200s (Рыжов 2001, c. 294)). Probably, this TPC includes kilns in Kady-Koy in ancient, apparently, early medieval times (Сарновски 2005, с. 119-132; Сарновски, Савеля 2000, с. 61 ; Филиппенко 1998, с. 116) and in the delta of the Belbek River, 1600s - beginning of the 1800s (Савеля 1989, л. 20-22).

Subgroup 1 (fig. 2). The paste is compact, well mixed, apparently made of clay from Miocene deposits. Finished tiles are red or purple (10R7/6; $2.5 \mathrm{YR} 6 / 6 ; 2.5 \mathrm{YR} 7 / 6)$ and compact. The paste contains an admixture of lime, which concentrates in concretions with diameter of $0.05-0.2 \mathrm{~cm}$. The surface is coated with white engobe with yellow gradation (10YR8/4; 10,5YR8/3) on both sides. Finished tiles have engobe similar to the engobe of class 52 amphora of «ХК-95» (Романчук и др. 1995, c. 73-77). On the back side of Flanged tiles you can see the characteristic caverns, probably from burnt lime.

The chronology (tabl. 2) of the subgroup is the $1000 \mathrm{~s}-1^{\text {st }}$ half of the $1200 \mathrm{~s}$ (Klenina et al. 2018, p. 154-155). Lower chronological limit is connected with the production of Ich/4 because some tiles of Ich/1 from excavations of monastery complex on the Vinery cape (Fiolent area) have UF with extra width on upper edge. The upper date should be redefined due to the beginning of production of Ich/3. Flanged tiles. The soubgroup has 3 classes (supplement) and 18 variants ${ }^{3}$ (fig. 8; supplement). Class 1 (variants $1,5-6,10-$ fig. 8; supplement) was found during excavations of Chersonesos and Eski-Kermen (supplement). Class 2 (variant 7 - fig. 8; supplement) was found during excavations of Chersonesos (supplement). Flanged tiles have bad defined LC on the inner side. This is a chronoindicator* of the mid-

1. The addition of «ch» to the number of the group means "Chersonesos". It means, that this group belongs to the Chersonesos tile production center and that in the typologies of Chersonesos's tiles it traditionally has number «I» (Романчук 2004, c. 42). The name of tile production center is conditional. Its exact location is still discussed. The product range of tile production center has special molding compound, which differ from other building ceramics. It has compact texture, smooth molding compound and various amounts and forms of impurities of natural lime.

2. Radiogorka pier.

3. Ich/1/2-4, Ich/1/11-17 have no defined classes. 900s (Моисеев 2018a, с. 150-151, 153). Class 3 (variants 8-9- fig. 8; supplement) was found during excavations of Chersonesos (supplement).

Subgroup 2 (fig. 2). The paste is compact, well mixed, apparently made of clay from Miocene deposits. Finished tiles are red (2.5YR7/6; 2.5YR6/4; $5 Y R 7 / 6 ; 5 Y R 7 / 8)$. The paste contains a notable admixture of lime, the body of Flanged tiles have cracks of irregular shape formed during firing. Tiles of Ich/2 are delaminated. The surface is coated with white and sometimes light-green (2.5YR6/1; 5Y8/1) engobe. It covers facial side but not rear side. Products are rough due to the use of coarse backfill.

The chronology (tabl. 2) of the subgroup is the mid-1200s $-1^{\text {st }}$ half of the 1300s. (Лысенко, Тесленко 2002, с. 269-270; Klenina et al. 2018, p. 148, 151). Flanged tiles. The subgroup has 3 classes (supplement) and 41 variants ${ }^{4}$ (fig. 8-9; supplement). Class 1 (variants $1,3,15,30-$ fig. 8-9; supplement; tabl. 2) was found during excavations of Chersonesos and Eski-Kermen (supplement). It is the oldest one and the beginning of its production (Ich/2/1) is synchronous with a rebuilding of the block in the mid-1200s (Klenina et al. 2018, p. 151). Class 2 (variants 4 $5,7-12,14,16-22,25-26,35-36,39-41-$ fig. 8-9; supplement; tabl. 2) was found during excavations of Chersonesos and Eski-Kermen (supplement). Findings of the class are the most numerable and their production has been dated back to the prosperity of the South-Western Crimea in the $2^{\text {nd }}$ half of the $1200 \mathrm{~s}$. Class 3 (variants 6, 23- fig. 8-9; supplement; tabl. 2) was found during excavations of Chersonesos and Eski-Kermen (supplement).

Subgroup 3 (fig. 2). The paste is compact, well mixed, apparently made of clay from Miocene deposits. Finished tiles are from brownish-red to purple $(2.5 \mathrm{YR} 6 / 6 ; 2.5 \mathrm{YR} 6 / 8 ; 2.5 \mathrm{YR} 7 / 8 ; 5 \mathrm{YR} 5 / 6$; 5 YR6/6; 5YR6/8). The paste contains a notable admixture of lime (small spherical concretions). Fired tiles are compact and slightly delaminated. The surface is coated with yellow (10YR8/3) engobe and significantly delaminated. Flanged tiles. The subgroup has 3 variants (fig. 9; supplement). It was found during excavations of Chersonesos and Ilyaz-Kaya (supplement). Ich/3 is later than Ich/1 and has some similar morphological features: short LC. Therefore, the beginning of its production cannot be seen* before the turn of the 1000s-1100s, when Flanged tiles didn't have LC (tabl. 2).

Subgroup 4 (fig. 3). The paste is compact, well mixed, apparently made of clay from Miocene deposits. Finished tiles are from light-red to purple $(2.5 \mathrm{YR} 6 / 4 ; 2.5 \mathrm{YR} 6 / 8 ; 5 \mathrm{YR} 6 / 6)$. The paste contains an admixture of lime (points and occasional spherical concretions of this substance).

4. Ich/2/2, Ich/2/13, Ich/2/24, Ich/2/27-29, Ich/2/36-37 have no defined classes. 
Fired tiles are compact. The surface is sometimes coated with yellow $(7.5 \mathrm{YR} 7 / 6 ; 10 \mathrm{YR} 7 / 3)$ engobe. It covers facial side, not rear side.

Flanged tiles have FTF, well and badly formed UF, well and badly defined LC. Tiles were found during excavations of monastery complex on the Vinery cape (Fiolent area), Chersonesos and TPC on the Northern bank of Akhtiar bay (supplement). Findings from the monastery on the Vinery cape have analogies in morphology ${ }^{1}$ to the material from excavations of Semikarakorsk fortress (Моисеев 2015, с. 159-160). Therefore, chronology of Ich/4 is the $700 \mathrm{~s}$ - mid-1000s (Klenina et al. 2018, p. 156), but not later than the start of production of Ich/1 (tabl. 2). Flanged tiles. The subgroup has 3 classes (supplement) and 4 variants (fig. 9; supplement). Class 1 (variant 1 - fig. 9; supplement; tabl. 2) was found during excavations of monastery complex on the Vinery cape (Fiolent area) (supplement). It is the oldest one (has FTF) and dates back* to the edge of the $700 \mathrm{~s} / 800 \mathrm{~s}$ and, perhaps, earlier time. Class 2 (variant 2 - fig. 9; supplement; tabl. 2) was found during excavations of monastery complex on the Vinery cape (Fiolent area; supplement). Tiles of the class have bad defined UF. In addition, class 2 has analogies from the Semikarakorsk fortress (but without UF). The site has chronology of the 700s/800s-840s (Моисеев 2015, c. 156). Therefore, the class has chronology the $1^{\text {st }}$ half of the $800 \mathrm{~s}-$ mid- $800 \mathrm{~s}$. Class 3 (variants 3-4 - fig. 9; supplement; tabl. 2) was found during excavations of Chersonesos and TPC on the Northern bank of Akhtiar bay (supplement). They were producing tiles in the $2^{\text {nd }}$ half of the 800s-1000s (Klenina et al. 2018, p. 156), but not later than the start of production of Ich/1.

Subgroup 5 (fig. 3). The paste is compact, well mixed, apparently made of clay from Miocene deposits. Finished tiles are dark red (10R6/4; 10R6/6). The paste contains admixture of lime (concentrate in spherical concretions about 0.1$0.3 \mathrm{~cm}$ ), fine chamotte, sandstone quartz grit. There are fine pebbles and mica on rear side of the product. Fired tiles are compact. The surface is coated with white $(2,5 \mathrm{Y} 8 / 2)$ engobe.

The chronology (tabl. 2) of the subgroup is the $2^{\text {nd }}$ half of the $400 \mathrm{~s}-1^{\text {st }}$ half of the $600 \mathrm{~s}$ (Герцен, Манаев 2005, с. 322-325; Моисеев 2013, с. 171; Романчук 1976, с. 156-157, рис. 1: 1; Яшаева и др. 2018a, с. 334). Flanged tiles. (fig. 9; supplement) were found during excavations of Chersonesos and Mangup (supplement).

Group II. These items were molded of a porous paste with an admixture of chamotte meant to decrease its plasticity. The clay apparently originated from mid-Jurassic deposits. Baked tiles are in various shades of red, sometimes coated with sleazy whitish engobe.

1. The flanged tile has side flange with wedge-form. Also it has bad defined UF. Form of the LC is unknown.
The group is conditional. So far four TPC supplying tiles of this group have been discovered: Bodrak (Моисеев 2013, с. 170, 175; Паршина та ін. 2001 , с. $71-72$; Якобсон 1979 , с. $54-56$, рис. 29-30), Laspi with Batiliman and IlyazKaya sites (Домбровский 1974, с. 19, 21-22, рис. 7, 10; Паршина 1974, с. $78,81-82$, рис. 19: 9; 82: 10, 19, 32, 39-46; Паршина та ін. 2001, c. $67-68$; Фирсов 1990 , с. 406-407, 431-432, рис. 145, 159), Kanaka (Паршина та ін. 2001, c. 56-58; Якобсон 1979 , с. 48 -53, рис. 2628), Choban-Kule (Моисеев 2018b, с. 151, 154; Паршина та ін. 2001, с. 58-60; Якобсон 1979, с. $40-48$, рис. $20-25$ ) (fig. 1 ).

The products of the group were manufactured from the clay with a high degree of plasticity. Such raw material demanded from craftsmen to reduce plasticity to prevent cracking of tiles during shrinkage. Evidences of using this technology became a criteria to determine building ceramics as «group 2» («группа 2») in the historiography (Романчук 2004, с. 43).

Subgroup 1: TPC Bodrak (fig. 7). The paste is porous, well mixed (uniform distribution of admixtures), apparently made of clay from midJurassic deposits. Finished tiles are red, orange, rarely of burgundy color $(2.5 \mathrm{YR} 8 / 4 ; 2.5 \mathrm{YR} 7 / 6$; 5YR7/6; 5YR7/8). The paste contains admixture of lime (small amount of white and beige color nodules of different size), concretions of chamotte of irregular shape, quartz gravel and particles of ferrous compounds with ellipse and round form, which form the texture of chipping. The surface could be coated with engobe $(2.5 \mathrm{YR} 7 / 4 ; 2.5 \mathrm{YR} 6 / 2$; 2.5YR6/4).

The subgroup was being produced by TPC Bodrak (fig. 1). The lower chronological limit* of II/1 dates back to the $1^{\text {st }}$ half, probably closer to the mid-800s. It was determined by FTF on class 1 . Classes with UF are dated by the materials from excavations of the temple on Tuzlukh hill (860s - 880s - tabl. 3; Тесленко, Мусин 2015 , c. $17,21-22,131,134)$. It points on the active production of the subgroup. II/ 1 exists in the complex of the edge of the 800 s/900s from excavations of Mangup ${ }^{2}$ (Моисеев 2011, с. 174). The upper chronological limit of the subgroup is dated to the mid-900s and is determined by well-defined LC (Моисеев 2018b, с. 153-154). Flanged tiles. The subgroup has 6 classes (supplement) and 17 variants $^{3}$ (fig. 10; supplement). Class 1 (variants 6,17 - fig. 10; supplement; tabl. 3) was found during excavations of Chersonesos and the temple on Tuzlukh hill (supplement). The class

2. There is no tiles of soubgroup II/1 in the publication of the complex. Nevertheless, his methodology demands to make chopping and photo of all groups and subgroups of tiles, which were defined in the complex and after some time II/1 was found in this data.

3. II/1/4, II/1/11-12, II/1/14, II/1/16 have no defined classes. 
Moisieiev, D. A. Medieval Flanged Tiles from the South-Western Crimea...

Table 3. Chronology of groups II, III, IV

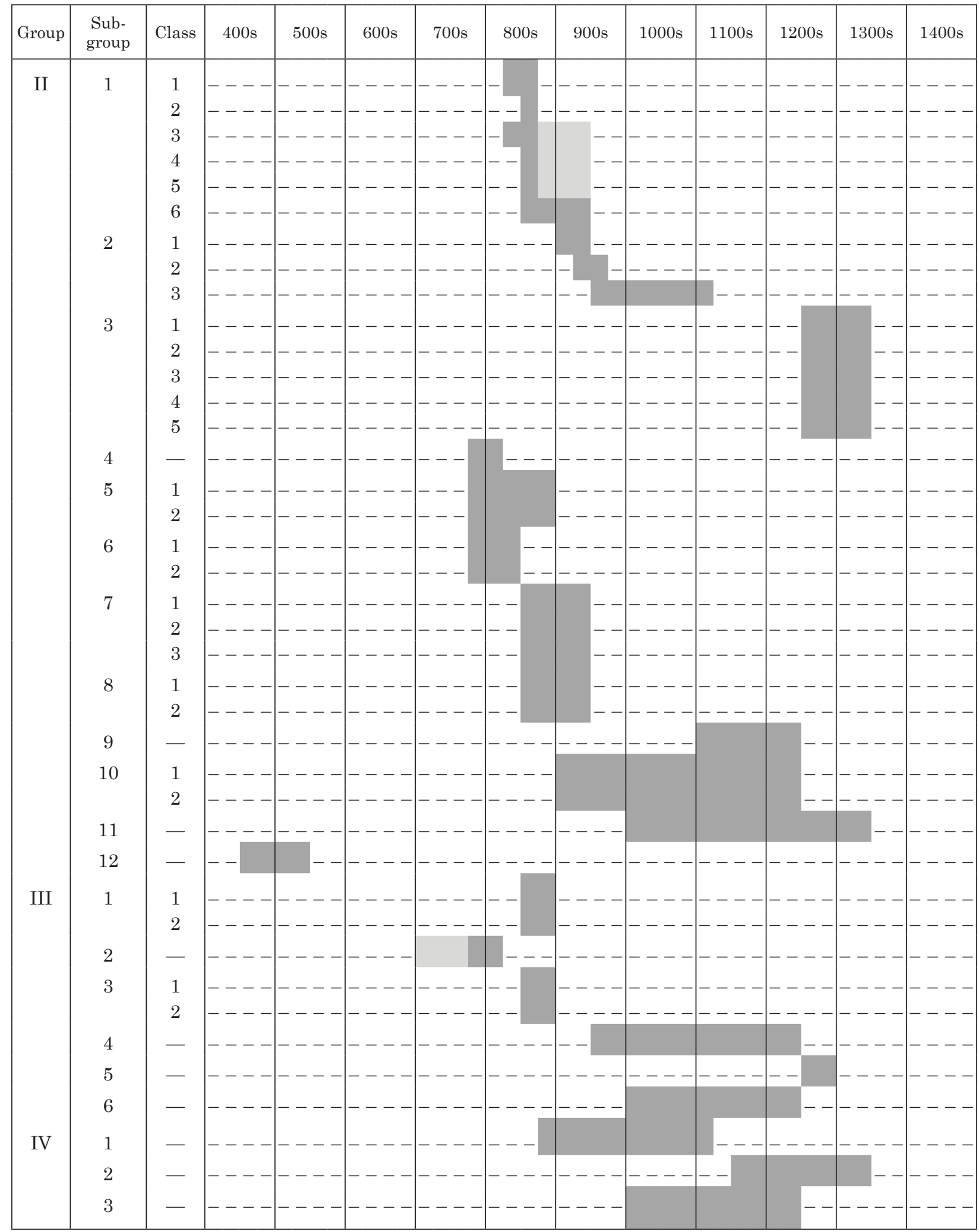

has FTF. However, the first building period of the temple begins in the middle $-2^{\text {nd }}$ third of the 800s (Тесленко, Мусин 2015, с. 17, 21-22, 268). Therefore, class 1 attributes to the mid-800s. Class 2 (variant 7 - fig. 10; supplement; tabl. 3) was found during excavations of Chersonesos (supplement). Findings have FTF and bad defined UF. It means that the class was being produced during the time of formation of tradition to make Flanged tiles with UF. The chronology of the class is the $850 \mathrm{~s}-860 \mathrm{~s}$. Class 3 (variants $8-10$, 13, 15 - fig. 10; supplement; tabl. 3) was found 
during excavations of Chersonesos, Simeiz and the temple on Tuzlukh hill (supplement). Finds from excavations of the temple give us possibility to date the class to the time of the $2^{\text {nd }}-3^{\text {rd }}$ third of the 800s (Тесленко, Мусин 2015, с. 17, 2122, 131, 268). Class 4 (variant 2 - fig. 10; supplement; tabl. 3) was found during excavations of Eski-Kermen (supplement). The chronology of the class is connected to the dating of classes 3 and 6. Class 5 (variant 1 - fig. 10; supplement; tabl. 3) was found during excavations of Eski-Kermen and settlement Varnutka (supplement). The class is close to class 4 by its morphology (and, maybe, time). Class 6 (variants 3, 5- fig. 10; supplement; tabl. 3) was found during excavations of Eski-Kermen and Partenit (supplement). There is no flanged tile with lower part of tile. However, in the catalog of building ceramics of Chersonesos there is flanged tile «Y38-9» without LC (Романчук 2004, рис. 46: 2). The upper part of mark «Y38-9» is similar to the upper part of mark II/1/5. It is possible that flanged tile «У38$9 »$ belongs to class 6 . If this suggestion is correct, dating* of class 6 is time after the mid-900s.

Subgroup 2: TPC is unknown (ChobanKule?) (fig. 3). The paste is porous, bad mixed, apparently made of clay from mid-Jurassic deposits. Finished tiles are red (10R5/6). The paste contains admixture of lime (small amount of beige color spherical nodules), concretions of chamotte with irregular shape (red color, small and large size with; black color medium and large size) and a lot of quartz sand. The surface could be coated with light-yellow engobe (2.5YR7/4; 5YR7/4).

The place of the production of the subgroup is unknown. Perhaps, it was TPC Choban-Kule (fig. 1). For instance, finds from archaeological works on the site of TPC are very close and similar to II/2, but with small variations: more admixture of chamotte and lime ${ }^{1}$. The last admixture makes chips of tiles variegated. The chronology of II/2 is disputable. At first, it was dated to the $2^{\text {nd }}$ half of the $1200 \mathrm{~s}^{2}$ (Завадская 2008, с. 294, 305). However, the complex from the temple on the Unnamed cape (mid-900s) and from the prison-tank in block VII of Chersonesos (the end of the $1000 \mathrm{~s}$ - beginning of the 1100s) contradict this chronology (Моисеев 2018b, с. 154). Flanged tiles of the subgroup have some classes without LC and some with it. Therefore, we can date II/2 to the time of the $900 \mathrm{~s}$ - beginning of the 1100s (tabl. 3). Flanged tiles. The subgroup has 3 classes (supplement) and 15 variants $^{3}$ (fig. 10; supplement). Class 1 (variants 1-7, 9, 11, 13-14 - fig. 10; supplement; tabl. 3) was found during excavations of Chersonesos, Eski-

1. Collection of Choban-Kule survey in 1962 in Alushta museum of local history.

2. I. A. Zavadskaya identified and publicized soubgroup 2 at first time. In her researches it has name «группа 3» ("group 3») (Завадская 2008, с. 301).

3. II/2/15 has no defined classes.
Kermen, Ilyaz-Kaya, Isar-Kaya, Laspi, Mangup, Oreanda, Partenit, settlement Varnutka and the temple on the Unnamed cape (supplement). The chronology* is the $1^{\text {st }}$ half of the 900 s (one variant of class 1 has a transitional bad defined LC). Class 2 (variant 8 - fig. 10; supplement; tabl. 3) was found during excavations of the temple on the Unnamed cape (supplement). The chronology is the mid-900s (Моисеев 2018b, с. 151-152, 154). Class 3 (variants 10, 12 - fig. 10; supplement; tabl. 3) was found during excavations of Chersonesos, Gurzuf fortress, Partenit, settlements Oreanda and Upper Massandra (supplement). Flanged tiles of the class don't have LC - so they were dated back* to the $2^{\text {nd }}$ half of the 900 s - beginning of the $1100 \mathrm{~s}$.

Subgroup 3: TPC Bodrak (?) (fig. 3). The paste is porous, bad mixed, with rough surface, apparently made of clay from mid-Jurassic deposits. Finished tiles are red (10R4/8). The paste contains admixture of lime, concretions of red chamotte (sometimes it can be black or nearly black).

The place of the production of the subgroup is unknown, but most probably it was TPC Bodrak (Моисеев 2018a, с. 171). The chronology of II/3 is the same as final building periods of Eski-Kermen fortress (the $2^{\text {nd }}$ half of the $1200 s-1^{\text {st }}$ half of the 1300s - tabl. 3), possibly, slightly earlier and later time (Завадская 2008, с. 305-306; Тесленко 2020, с. 252). Flanged tiles. The subgroup has 5 classes (supplement) and 33 variants ${ }^{4}$ (fig. 10-11; supplement). Class 1 (variants 1, 4, 7, 9, 17, 22, 28-33 - fig. 10-11; supplement) was found during excavations of Chersonesos, Eski-Kermen, Ilyaz-Kaya, Isar-Kaya, settlements Laspi, Mangup, Varnutka and the temple on Krestovaya mountain in Alupka (supplement). Class 2 (variants $1,5-6,8,18-19$, 21, 23-24 - fig. 10-11; supplement) was found during excavations of Chersonesos, Eski-Kermen, Ilyaz-Kaya and the settlement Upper Massandra (supplement). Class 3 (variants 12, 16, 20, $29-$ fig. 11; supplement) was found during excavations of Chersonesos, Eski-Kermen, Ilyaz-Kaya, Isar-Kaya, Partenit and settlement Varnutka (supplement). Class 4 (variant 15 - fig. 11; supplement) was found during excavations of Chersonesos, Eski-Kermen, Ilyaz-Kaya, Isar-Kaya, Partenit and settlement Varnutka (supplement). Flanged tiles of the class were found during excavations of complexes that had formed in the late 1200 s (Мыц 1990, с. 240) or had started forming at the turn of the 1200s - 1300s (Паршина, 1988, с. 38 - 39, 46-48; Романчук 2004, с. 65 ; Симонова 1980, с. 104) or in the 1300s (Якобсон 1979 , c. 132). The fact, that one class is found in the layers, which belong to two consecutive periods, indicates, that the production of it began just before the destruction of Chersonesos and Isar-

4. II/3/2-3, II/3/25-26 have no defined classes. 
Kaya in the late 1200 s. Class 5 (variants $10-11$, 13-14, 27 - fig. 11; supplement) was found during excavations of Chersonesos and Eski-Kermen (supplement). Handicraft mark II/3/5 class 5 has some similarity with II/3/28 class 1 . Therefore, we can say that they have chronological connection.

Subgroup 4: TPC Ilyaz-Kaya (fig. 3). The paste is porous, bad mixed, apparently made of clay from mid-Jurassic deposits. Finished tiles are red $(10 \mathrm{R} 7 / 6 ; 2.5 \mathrm{YR} 7 / 6 ; 5 \mathrm{YR} 6 / 8)$. The paste contains admixture of clotted lime, big concretions of red chamotte, oligoclase gravel and argillite. Sometimes there are numerous cavities in the chip.

The subgroup was being produced by TPC Ilуaz-Кауа (Паршина 1993, с. 107-109; Паршина та ін. 2001, с. 56-58), located in Laspi bay under the Ilyaz-Kaya mountain in Choban-Tash area (fig. 1). Flanged tiles. The soubgroup has 5 variants and one class $^{1}$ (fig. 11; supplement). They were found during excavations of Oreanda, Partenit and TPC Ilyaz-Kaya (supplement). The subgroup has FTF. Therefore, it is attributed* to the edge of the $700 \mathrm{~s} / 800 \mathrm{~s}$ and some earlier time (tabl. 3).

Subgroup 5: TPC Ilyaz-Kaya (fig. 3). The paste is porous, bad mixed, apparently made of clay from mid-Jurassic deposits. Finished tiles are red (2.5YR7/8; 2.5YR6/8; 5YR7/6; 5YR7/8). The paste contains admixture of solid clotted lime, a lot of small and medium concretions of red (2.5YR6/6; 5YR6/6) and black (2.5YR6/1) chamotte. Facial side and side edge of the side flanges are covered with light-yellow engobe (2.5YR7/4; 5YR7/4).

The subgroup was being produced by TPC Ilyaz-Kaya. Flanged tiles have FTF, UF, well defined LC. They were found during excavations of the temple on the Unnamed cape, where II/5/10 derived from "the first set» of the roof of the temple. It was built in the $2^{\text {nd }}$ half of the 800 s and was destructed in the mid-900s (Яшаева 2005, c. 484-485). Therefore, chronology* of II/5 is the edge of the $700 \mathrm{~s} / 800 \mathrm{~s}-2^{\text {nd }}$ half of the $800 \mathrm{~s}$ (tabl. 3). Flanged tiles. The subgroup has 3 classes (supplement) and 12 variants $^{2}$ (fig. 11-12; supplement). Class 1 (variants 1, 3, 9-11fig. 11-12; supplement) was found during excavations of Chersonesos, Partenit and temple on the Unnamed cape (supplement). Class 2 (variant 6 - fig. 11; supplement) was found during excavations of Chersonesos, Partenit, Biuk-Isar and settlement Limena (supplement). Class 3 (variant 12 - fig. 12; supplement) was found during excavations of monastery complex on the Vinery cape (Fiolent area) (supplement). The class has FTF. Therefore, it is attributed* to the edge of the $700 \mathrm{~s} / 800 \mathrm{~s}$.

Subgroup 6: TPC Kanaka (fig. 3). The paste is porous, well mixed, apparently made of clay

1. II/4/5 has no defined class.

2. II/5/2, II/5/4-5, II/5/7-8 have no defined classes. from mid-Jurassic deposits. Finished tiles are red $(2.5 \mathrm{YR} 7 / 4 ; 2.5 \mathrm{YR} 6 / 8 ; 5 \mathrm{YR} 7 / 4)$. The paste contains admixture of chamotte, quarz gravel, sand. Bodies of Flanged tiles have cracks of irregular shape.

II/6 was being produced by TPC Kanaka (fig. 1). It has FTF and was found in layers of the first building period of the temple on Tuzlukh hill, which begins in the middle $-2^{\text {nd }}$ third of the 800s (Тесленко, Мусин 2015, с. 17, 21-22, 268). Therefore, II/ 6 is attributed* to the edge of the $700 \mathrm{~s} / 800 \mathrm{~s}-1^{\text {st }}$ half of the $800 \mathrm{~s}$ (tabl. 3). Flanged tiles. The subgroup has 2 classes ${ }^{3}$ (fig. 12 ; supplement). Classes 1 (fig. 12 ; supplement) and 2 (fig. 12; supplement) were found during excavations of TPC Kanaka and the temple on Tuzlukh hill.

Subgroup 7: TPC Kanaka (fig. 3). The paste is porous, well mixed with fine-grained structure apparently made of clay from mid-Jurassic deposits. Finished tiles are red $(10 \mathrm{R} 7 / 6 ; 2.5 \mathrm{YR} 7 / 6)$. The paste contains admixture of lime (small points), small concretions and ramentums of chamotte of red color ceramic (shows through the surface of the flanged tile), small particles of ferrous compounds, quartz gravel and sand. Surface is covered with light-pink engobe (5YR7/2; 5YR7/3).

II/7 was made by TPC Kanaka (fig. 1). It has well defined UF and LC. Therefore, II/7 is attributed* to the $2^{\text {nd }}$ half of the $800 \mathrm{~s}-1^{\text {st }}$ half of the 900s (tabl. 3). Flanged tiles. The subgroup has 3 classes (supplement) and 3 variants (fig. 12; supplement). Class 1 (variant 1 - fig. 12; supplement) was found during excavations of Partenit and TPC Kanaka (supplement). It is the earliest due to bad defined UF. Class 2 (variant 2 - fig. 12; supplement) was found during excavations of Partenit (supplement). Class 3 (variant 3 - fig. 12; supplement) was found during excavations of Partenit and the temple on Tuzlukh hill (supplement). It was dated by the origin of the material from excavations of the temple on Tuzlukh hill from the layer of destruction no later than the mid-900s (Тесленко, Мусин 2015, c. 268).

Subgroup 8: TPC Ilyaz-Kaya (fig. 4). The paste is solid, porous, bad mixed with rough surface, apparently made of clay from mid-Jurassic deposits. Finished tiles are red (2.5YR6/6; 2.5 YR7/6; 2.5YR6/8) often with overburnt surface. The paste contains admixture of lime (small amount in form of points and clots), a lot of medium-sized chamotte particles of red and black color ceramic (shows through the facial and rear surfaces of the flanged tile), argillite and ferrous compounds. Surface is covered with white $(7.5 \mathrm{YR} 8 / 2 ; 7.5 \mathrm{YR} 8 / 3)$ or in color of the tile (7.5YR6/3; 5YR6/6; 5YR7/4; 7.5YR7/4) engobe.

The subgroup was being produced by TPC Ilyaz-Kaya (fig. 1). Its Flanged tiles are well rep-

3. There are no defined variants in the subgroup 
resented in the complex of the $2^{\text {nd }}$ building period of temple on Tuzlukh hill (Тесленко, Мусин 2015 , с. $22-26,64,73,268$, рис. 3.1 : 2; 3.7: 1). In addition, II/8 has Flanged tiles with bad defined LC (II/8/4). Therefore, the chronology of the subgroup* is the $860 \mathrm{~s} / 880 \mathrm{~s}-$ mid-900s (tabl. 3). Flanged tiles. II/8 has 2 classes (supplement) and 7 variants $^{1}$ (fig. 12; supplement). Class 1 (variant 1 - fig. 12; supplement) was found during excavations of TPC Ilyaz-Kaya and the temple on Tuzlukh hill (supplement). Class 2 (variant $4-$ fig. 12; supplement) was found during excavations of Partenit (supplement).

Subgroup 9: Unknown TPC (fig. 4). The paste is porous, bad mixed with rough surface, apparently made of clay from mid-Jurassic deposits. Finished tiles are red $(2.5 \mathrm{YR} 7 / 6 ; 2.5 \mathrm{YR} 6 / 6)$. The paste contains admixture of points and large clots of lime, a lot of red (10R6/6) and black (2.5YR6/1) chamotte and argillite. Surface is covered with light-yellow engobe (10R8/1).

The place of production of the II/9 is unknown. The chronology is the $1100 \mathrm{~s}-1^{\text {st }}$ half of the 1200s (tabl. 3) (Klenina et al. 2018, p. 157, 175, 181, fig. 2: 2, group 2 v. 1). Flanged tiles. The subgroup has 1 class (supplement) and 1 variant (fig. 12; supplement). Class 1 was found during excavations of Chersonesos and Ilyaz-Kaya (supplement).

Subgroup 10: Unknown TPC (fig. 4). The paste is porous, well mixed, apparently made of clay from mid-Jurassic deposits. Finished tiles are red $(2.5 \mathrm{YR} 7 / 6 ; 5 \mathrm{YR} 6 / 6 ; 5 \mathrm{YR} 6 / 8)$. The paste contains admixture of lime, which makes cracks of irregular shape in the flanged tile body, and red $(2.5 Y R 4 / 6)$ chamotte. Surface is covered with solid white $(2.5 \mathrm{YR} 8 / 1)$ engobe.

The place of the production of the subgroup is unknown. Flanged tiles were found in displaced layers of the temple on Devich'ya hill near Chersonesos (Яшаева и др. 2018a, с. 121) and in layers of the mid-1200s - $1^{\text {st }}$ half of the 1300 s as the secondhand material (Klenina et al. 2018, p. 158-160). Thus, the chronology of II/9 belongs to the $900 \mathrm{~s}-1^{\text {st }}$ half of the $1200 \mathrm{~s}$ (tabl. 3). Flanged tiles. The subgroup has 2 classes (supplement) and 2 variants (fig. 12; supplement). Classes 1 (variant 1 - fig. 12 ; supplement) and 2 (variant 2 - fig. 12 ; supplement) were found during excavations of Chersonesos.

Subgroup 11: Unknown TPC (fig. 4). The paste is porous, bad mixed, fragile, apparently made of clay from mid-Jurassic deposits. Finished tiles are dark-red (2.5YR5/6; 5YR5/4). The paste contains admixture of small amount of lime, a lot of small red (2.5YR4/6) and black chamotte. The surface of tiles is black (sooted effect), which is the result of an oxidative firing.

The place of the production of II/11 is unknown. The chronology is the $1000 \mathrm{~s}-1^{\text {st }}$ half of the $1300 \mathrm{~s}$

1. II/8/2-3, II/8/5-7 have no defined classes. (tabl. 3) (Klenina et al. 2018, p. 147-150, 157). Flanged tiles (fig. 12; supplement) were found during excavations of Chersonesos and Partenit (supplement).

Subgroup 12: TPC Bodrak (fig. 4). The paste is porous, bad mixed, apparently made of clay from mid-Jurassic deposits. Finished tiles are red (2.5YR6/4; 5YR6/6). The paste contains admixture of small amount of lime, chamotte, particles of ferrous compounds and unrecognized black concretions.

The subgroup was being produced on TPC Bodrak (fig. 1). The chronology is the $2^{\text {nd }}$ half of $400 \mathrm{~s}-1^{\text {st }}$ half of 500s (tabl. 3) (Моисеев 2014b, c. $169-170,175$ ). Flanged tiles (fig. 12; supplement) were found during excavations of Bodrak and Chersonesos (supplement).

Group III: TPC Suatkan. These items were molded of compact paste with barely noticeable additional components of various shades of the same colors or white color clay and have different admixtures (lime, chamotte, river sand, argillite and so on). They were apparently made of clay from early Cretaceous deposits. The baked tiles are in various shades of red and pale yellow. The surface of Flanged tiles is coated with compact light-yellow (7.5YR6/3; 7.5YR7/6; 2.5YR7/6; $2.5 \mathrm{YR} 8 / 2 ; 10 \mathrm{YR} 8 / 2 ; 7.5 \mathrm{YR} 7 / 6 ; 7.5 \mathrm{YR} 8 / 2 ; 5 \mathrm{YR} 7 / 6$; 5YR7/6; 5YR6/8) or red (5YR7/6) engobe. TPC, that was producing the group, was discovered in gully of the Suatkan stream (fig. 1) ${ }^{2}$.

Subgroup 1 (fig. 4). The paste is compact and well mixed, apparently made of clay from early Cretaceous deposits. Finished tiles are red (2.5YR6/8; 5YR6/8), with barely noticeable additional components of light-red color. The paste contains admixture of lime (cavities and clots no more than $0.1 \mathrm{~cm}$ long and $0.05 \mathrm{~cm}$ width), mica, a little of large quartz gravel, dark sand (which is well differentiated and is a main feature in determining of the subgroup), argillite (little solitary compounds) and very little cavities of air. There is no engobe.

III/1 was found during excavations of the Lagernaya Gully on Mangup (imbrex), the edge of the 800s_-900s (Моисеев 2011, с. 174, 181, рис. 4: $6)$, where it was the late «repair» (Моисеев 2011, c. 180, 182). The subgroup has UF. Therefore the chronology of it is the $2^{\text {nd }}$ half of the 800 s (tabl. 3 ). Flanged tiles. III/1 has 2 classes (fig. 12; supplement). Classes 1 and 2 were found during excavations of TPC Suatkan (supplement).

Subgroup 2 (fig. 4). The paste is solid, compact and bad mixed with insignificant delaminations, apparently made of clay from early Cretaceous deposits. Finished tiles are red (5YR6/4; 5YR7/8; 5YR5/8; 10R6/6), with significant additional components of white (10YR7/4, 10YR8/2) clay. This addition is represented on chips with

2. Excavations were managed by author in 2012 -2013. Unpublicized. 
stains and lenses (it makes chips variegated). The paste contains admixture of lime and mostly dark chamotte. Surface is covered with non-solid light-yellow (7.5YR6/3; 7.5YR7/6; 2.5YR7/6) or red (5YR7/6) engobe.

Tiles have FTF. Therefore, subgroup is dated* to the time of the edge of the $700 \mathrm{~s} / 800 \mathrm{~s}$ or earlier time (tabl. 3). Flanged tiles has 2 variants (fig. 12; supplement). They were found during excavations of Chersonesos, Mangup, Suren and TPC Suatkan (supplement).

Subgroup 3 (fig. 4). The paste is fragile, porous and bad mixed, apparently made of clay from early Cretaceous deposits. Finished tiles are red (2.5YR6/8). The paste contains admixture of big particles of red ceramic chamotte (10R6/6; $10 R 6 / 8 ; 10 R 5 / 8)$. Surface is covered with solid yellow (10YR7/6) or red (5YR5/8) engobe. Tiles have significant stratification.

III/3 has bad and well-defined UF. They were found during excavations of the "Markevich» basilica $^{1}$ (the late $800 \mathrm{~s}-1^{\text {st }}$ half of the $900 \mathrm{~s}$ ) (Науменко и др. 2017, с. 52), the Lagernaya Gully on Mangup (the edge of the 800s-900s) (Моисеев 2011, с. 174, 180) and on-ground temple on Devich'ya Hill, tomb 4 (860s-880s) (Яшаева и др. 2018a, с. 123). III/3 has more archaic features than III/1. Therefore, it is dated to the time of the $2^{\text {nd }}$ half of the 800 s (tabl. 3). Flanged tiles. The subgroup has 2 classes (supplement) and 3 variants (fig. 12; supplement). Class 1 (variant 1 - fig. 12 ; supplement) was found during excavations of Chersonesos, the "Markevich" basilica and settlement Qoca-Sala (supplement). Class 2 (variants 2-3- fig. 12; supplement) was found during excavations of the «Markevich» basilica and Mangup (supplement).

Subgroup 4 (fig. 4). The paste is compact and well mixed, apparently made of clay from early Cretaceous deposits. Finished tiles are yellow (5Y8/6; 5Y7/3; 5Y7/4). The paste does not contain any admixtures.

The chronology of the subgroup is not clear now. Lower chronological limit is determined by the dating of III/1 and III/6. Upper - by the chronology of III/5. Thus, III/4 is dated to the $2^{\text {nd }}$ half of the $900 \mathrm{~s}-1^{\text {st }}$ half of the $1200 \mathrm{~s}$ (tabl. 3). The chronology needs to be clarified. Flanged tiles. (fig. 12; supplement) were found during excavations of TPC Suatkan (supplement).

Subgroup 5 (fig. 5). The paste is compact and well mixed, apparently made of clay from early Cretaceous deposits. Finished tiles are yellow $(5 \mathrm{Y} 8 / 6 ; 5 \mathrm{Y} 7 / 6 ; 2,5 \mathrm{Y} 7 / 4)$. The paste contains admixtures of lime, big particles of black ceramic chamotte, particles of ferrous compounds and a lot of sand that makes finely grained structure of the chip.

1. Archaeological survey was managed by author in 2013.
III/5 was found during excavations of layers of destruction of the $2^{\text {nd }}$ half of the 1200s (tabl. 3) in central block in Eski-Kermen (Завадская 2008, c. 294) ${ }^{2}$. This allows to attribute the subgroup to this time. Flanged tiles. The subgroup has 1 variant (fig. 12; supplement) that was found during excavations of TPC Suatkan (supplement).

Subgroup 6 (fig. 5). The paste is compact and well mixed, apparently made of clay from early Cretaceous deposits. Finished tiles are yellow $(2,5 \mathrm{Y} 7 / 4 ; 5 \mathrm{Y} 7 / 6 ; 5 \mathrm{Y} 8 / 6)$, with barely noticeable additional components of various shades of red. The paste contains admixture of organic compounds, which after baking produced tiny cavities, as well as particles of argillite (with size $0.1-0.2 \mathrm{~mm}$ ) and river sand. The surface is coated with compact light-yellow (10YR7/6; 10YR6/4) engobe.

The chronology is the $1000 \mathrm{~s}$ - mid-1200s (tabl. 3) (Klenina et al. 2018, p. 160). Flanged tiles. The subgroup has 1 class (supplement) and 3 variants (fig. 12; supplement). Class 1 was found during excavations of Chersonesos, Eski-Kermen, Partenit and TPC Suatkan (supplement).

Group VI. Baked tiles are red (2.5YR6/8; 5YR6/8; 5YR6/4; 5YR7/8; 5YR5/8; 10R6/6), orange- or straw-colored (10YR8/2). The solid, porous, badly mixed paste contains lime, chamotte, particles of black argillite, ferrous compounds and sand. The surface is coated with white $(7.5 \mathrm{YR} 6 / 3$; 7.5YR7/6; 2.5YR7/6; 2.5YR8/2; 10YR8/2; $7.5 \mathrm{YR} 7 / 6 ; 7.5 \mathrm{YR} 8 / 2 ; 5 \mathrm{YR} 7 / 6$; 5YR7/6; 5YR6/8) or red (5YR7/6) engobe with different density.

It is not possible to determine the probable place of origin of raw materials because the group unites most likely non-Crimean, imported products (Klenina et al. 2018, p. 161). It is possible that each subgroup of the group represents a separate TPC.

Subgroup 1 (fig. 5). The paste is fragile, porous, bad mixed. Finished tiles are orange (5YR8/4) or light-yellow (7.5YR7/6; 5YR8/4) color. The paste contains admixture of lime, chamotte.

Tiles are dated to the time of the end of the 800s - beginning of the 1100s (tabl. 3) (Klenina et al. 2018, p. 160; Рыжов, Седикова, 1999, с. 326; Рыжов, 1998, л. 8-9). Flanged tiles (fig. 12; supplement) were found during excavations of Chersonesos (supplement).

Subgroup 2 (fig. 5). The paste is solid, porous, well mixed. Finished tiles are red $(2.5 \mathrm{YR} 8 / 4$; 2.5YR6/6; 7.5YR6/3; 5YR7/6; 5YR6/4; 5YR6/8). The paste contains admixture of chamotte, black argillite and ferrous compounds.

Tiles are dated to the time of the $2^{\text {nd }}$ half of the $1100 \mathrm{~s}-1^{\text {st }}$ half of the $1300 \mathrm{~s}$ (tabl. 3) (Klenina et al. 2018, p. 147-148, 160-161). Flanged tiles (fig. 12; supplement) were found during excavations of Chersonesos (supplement).

2. The author made the identification of artefactual remains on the site of excavations of central block of Eski-Kermen in 2003-2008. 
Subgroup 3 (fig. 5). The paste is solid, porous, well mixed. Finished tiles are orange (5YR7/3; 5YR7/6; 7.5YR6/8; 10YR7/3). The paste contains admixture of lime, roundish chamotte, ferrous compounds and sand.

Roof tiles are dated to the time of the $1000 \mathrm{~s}$ mid-1200s (tabl. 3) (Klenina et al. 2018, p. 147148, 160-161). Flanged tiles (fig. 12; supplement) were found during excavations of Chersonesos and Taman fortress (supplement).

Conclusions. The main aim of technological-morphological typology of medieval building ceramics from South-Western Crimea is localization of tile production centers and building on this foundation of formalized description of a material in such a large region. Application of such typology to the materials from various archaeological sites (32) showed relations between different parts of South-Western Crimea and, most importantly, evidences of an extensive tile production industry in medieval times. Products of different tile production centers were determined among materials from different sites based on division of building ceramics into groups — subgroups. Division of flanged tiles to subgroups - variants classes allowed to date investigated materials. The correlation of results of dating and typologization on different sites, sometimes located on opposite borders of the territorial framework of the study (for example, Chersonesos and the temple in Tuzlukh hill) showed a complete coincidence of chronological conclusions. It proved the accuracy of results and high potential for universality of the investigation.

Groups, subgroups and sometimes classes dated within following periods: the middle of the 400s600s (I/2; Ich/5; II/12), 700s-850/860s (I/1, classes $1-2$, 5 ; Ich/4, classes $1-2$; II/ 1 , classes $1-2$; II/4; II/5; II/6; III/2), 850/860s - the middle of the 900/1000s (I/1, classes $2-4 ; \mathrm{I} / 5$; II/1, classes $3-6$; II/2, classes $1-2$; II/5; II/7; II/8; II/10; III/1; III/3; IV/1), the middle of the $900 / 1000$ s - first half of the $1200 \mathrm{~s}(\mathrm{I} / 6$; Ich/1; Ich/3; Ich/4, class 3 ; II/2, class 3; II/9; II/10; II/11; III/4; III/6; IV/2; IV/3), the second half of the $1200 \mathrm{~s}(\mathrm{I} / 3 ; \mathrm{Ich} / 2 ; \mathrm{II} / 3$; III/5; IV/2), the edge of the $1200 \mathrm{~s} / 1300 \mathrm{~s}$ - first half of the 1300 s $(\mathrm{I} / 4$, classes $1-3$; Ich/2, classes $2-3$; II/3), second half of the 1300 s — beginning of the 1400s (I/4, classes 3-4). Materials belonging to the periods of the middle of the $400 \mathrm{~s}-600 \mathrm{~s}$, the $850 / 860$ s - the middle of the $900 / 1000$ s, the second half of the 1200s have a well-developed chronology due to the well-investigated archaeological material and sites of these periods in general. Less obvious is the chronology of material with date of the middle of the $700 \mathrm{~s}-850 / 860 \mathrm{~s}$, the edge of the $1200 \mathrm{~s} / 1300 \mathrm{~s}$ - first half of the 1300 s and the second half of the $1300 \mathrm{~s}$ - beginning of the 1400s. It still needs to be improved. Building ceramics, attributed to the middle of the 900/1000s - first half of the 1200s has a doubted and «conditional» chronological position. It must be admitted that the work on the chronological stratification of flanged tiles of this period has just begun.

In addition, for the first time the article fundamentally described tiles from seven tile production centers localized by groups and subgroups: Bodrak (subgroups II/1, II/3, II/5, II/12), Ilka (group I), Ilyaz-Kaya / Batiliman (subgroup II/4), Kanaka (subgroups II/6 - 8), Suatkan (group III), Chersonesos (group Ich) and Choban-Kule (probably subgroup II/2). There were also described imports from at least two tile production centers (subgroups IV/1, 3 and IV/2) with unknown localization outside the Crimea. The localization of production for some subgroups (II/9, II/10, II/11) was unsuccessful. But with the large number of pottery production centers from medieval Crimea, recorded in the classical study of the problem in 2001 by O. O. Parshina and her co-authors, this scientific task should be successfully solved in future researches.

\section{SUPPLEMENT}

\section{TECHNOLOGICAL AND MORPHOLOGICAL TYPOLOGY OF MEDIEVAL BUILDING CERAMICS (TEGULAE) FROM THE SOUTH- WESTERN CRIMEA. ANALOGIES FROM A LITERATURE AND UNPUBLICIZED EXCAVATIONS}

Acronyms mean:

a. low upper / side flange - L; medium upper / side flange - M; high upper / side flange - H; trapezoidal form - Tf; rectangle form - REf; triangle form - 3f; roller form - ROf; well defined - WD; bad defined $\mathrm{BD}$; false top flange - FTF;

b. CH - Chersonesos; EK - Eski-Kermen; MK Mangup-Kale; PART.85-88 - excavations in the Partenit in 1985-1988 on the site of "Krym resort»" ${ }^{1}$ (Паршина 1991, с. 70, 71-73; 2002, с. 93); VAR Varnutka; TH-Temple - temple on the hill of the Tuzlukh; TPC B - tile production center Bodrak; TPC IL — tile production center Ilka; TPC IK — tile production center Ilyaz-Kaya ${ }^{2}$; TPC K - tile production Kanaka $^{3}$ (Якобсон 1979, с. 48-49); TPC S - tile production Suatkan ${ }^{4}$.

\section{GROUP I}

\section{SUBGROUP I/ 1}

Class 1.Variants: 1, 6, 8-9 and 15-16. Upper edge: FTF or clear. Side flange: Tf/M. Lower edge: bend (90$135^{\circ}$ ) / WD. Were found on: settlement Baga (Якобсон

1. Collection aren't publicized now and there are in funds of Alushta museum of local history.

2. Collection aren't publicized now. Fragments were found during excavations in 1992 by E. A. Parshina and non-archaeological survey by author.

3. Collection aren't publicized now and there are in funds of Alushta museum of local history.

4. Survey was managed by author in 2012-2013 (Moисеев и др. 2013; 2014). Unpublicized. 
1970, с. 157 , табл. I: 16 ); CH (Романчук 2004, табл. 24: уз2/260в; Якобсон 1979 , с. 25 , рис. 10: 258; Яшаева и др. 2018b, с. 123); МK (Моисеев 2011, с. 178, рис. 3: 25, 47-50; Тиханова 1953 , с. 431 , табл. $1: 1-2$ Якобсон 1979, с. 101, рис. 63: 99-101); settlement Simeiz (Паршина 1974, с. 87, рис. 27: 28-29); TPC IL (Моисеев 2014a, с. 312, рис. 14: I-IV); VAR (Якобсон 1970, с. 159 , табл. III: $11,15,246)$; settlement Upper Oreanda (Паршина 1974, с. 89, рис. 31).

Class 2. Variants: 10-11. Upper edge: clear. Side flange: Tf/L. Lower edge: bend $\left(\geq 135^{\circ}\right) / \mathrm{WD}$. Were found on: settlement Baga (Якобсон 1970, с. 157, табл. I: 16); MK (Моисеев 2011, с. 178, рис. 3: 26-27).

Class 3. Variant: 7. Upper edge: ROf/L. Side flange: Tf/M. Lower edge: unknown. Were found on: TPC IL (Моисеев 2014a, с. 312, рис. 14: V-VII).

Class 4. Variants: $2-5,13,17$. Upper edge: Tf/L Side flange: Ref/L, Ref/M. Lower edge: bend $\left(\geq 135^{\circ}\right) /$ WD, with narrowing. Were found on: $\mathrm{CH}$ (Яшаева и др 2018b, с. 123); ЕK (Моисеев 2018b, с. 181, рис. 6: I); MK (Моисеев 2011, с. 178, рис. 3: 31, 51, 56; Тиханова 1953 , с. 431 , табл. 1: 3-4; Якобсон 1979, с. 101 , рис. 63: 94-98); Pampuk-Кауа (Якобсон 1970, с. 158, табл. II: 4); TPC IL (Моисеев 2014a, с. 307, 310-311, рис. 9: 12-13); settlement Markur (Якобсон 1970, с. 158 , табл. II: 4).

Class 5. Variant: 12. Upper edge: clear. Side flange: Ref/L. Lower edge: bend $\left(\geq 135^{\circ}\right) /$ BD. Were found on: MK (Моисеев 2011, с. 178, рис. 3: 28).

\section{SUBGROUP I/ 2}

Upper edge: clear. Side flange: REf/H. Lower edge: unknown. Were found on: MK (Герцен, Манаев 2005, с. $322-325,328-330,344)$; TPC IL (Моисеев 2013a, с. 33 - 34; Моисеев 2014a, с. 284).

\section{SUBGROUP $I / 3$}

Class 1. Variants: $3-7,9-10,12-13,17-20,22$, $24-25,29,32-39,43-45,50-51$. Upper edge: Tf/L M-H. Side flange: Ref/H, Tf/M. Lower edge: bad defined (smooth) transition to the surface, bend $\left(\approx 90^{\circ}\right) / \mathrm{WD}$ Were found on: CH (Klenina et al. 2018, p. 185, fig. 12: 94/10, 131/10; Романчук 2004, рис. 46: 4; Симонова 1980, с. 110 , рис. 2: 39); ЕК (Завадская 2008, с. 312 , рис. 2: 14; Моисеев 2018b, с. $185,187,189$, рис. 10; 12: I: 3; 14: I: 8 ; Паршина 1988, с. $38,41-43$, рис. 2 : друга у верхньому ряду; $3: 106,158 ; 6: 190-191)$; IsarКауа (Мыц 1987, с. 231, рис. 4: 1; occasional finds); MK (Мыц 1990, с. 229-230, рис. 5: 14, 18; 6: 20-21, 42; Романчук 1977 , с. 188 , рис. 8 : 71 ; Тиханова 1953 , c. 431 , рис. 1: $31,38,50,58$ ); TPC IL (Моисеев 2014b, c. 383,404 , рис. 3 : 3 ; 2018 a, p. 261 , рис. 2 : $2-9$, $13-$ $14,16-18,22,24-25,29$ ).

Class 2. Variants: $2,8,11,15-16,23,26,40,42,46-$ 47, 53. Upper edge: Tf/M-H. Side flange: Tf/H. Lower edge: bend $\left(\approx 90^{\circ}\right) /$ WD. Were found on: $\mathrm{CH}$ (Романчук 2004, рис. 38: 3; 42: 3-4; 44: 4; 46: 3; Якобсон 1979, с. 150 , рис. 97: 2, 282a); EK (Завадская 2008, с. 312 рис. 2: 12; Моисеев 2018a, с. 184, 186-187, рис. 9: I: 11; 12: 4; осcasional finds); TPC IL (Моисеев 2014b, с. 307 , рис. $6: 11-12 ; 2018$, p. 261 , рис. $2: 26$ ).

Class 3. Variants: 1, 14, 27, 30. Upper edge: Tf/MH. Side flange: Tf/M. Lower edge: bend $\left(\approx 90^{\circ}\right) / \mathrm{WD}$. Were found on: CH (Klenina et al. 2018, p. 185, fig. 12: 130/10); ЕK (Моисеев 2018b, с. 188-189, рис. 13: I: 14: II; occasional finds); TPC IL (Моисеев 2014b, c. 305 , рис. $4: 6-7)$.

\section{SUBGROUP I/4}

Class 1. Variants: 1, 6-7, 13, 16-20. Upper edge: Ref/M-H. Side flange: Tf/H, figurine-shaped upper edge and one more edge at the place of transition to the surface. Lower edge: bend $\left(\geq 135^{\circ}\right) / \mathrm{WD}$, with narrowing. Were found on: EK (Моисеев 2018b, с. 191-195, рис. 16: I; 17: 7; 18; 19: I-II; 20: I); MK (Мыц 1990, c. 230 , рис. 6 : $33-34,38$; Романчук 1977 , с. 184,187 , рис. 3: 29-30; 6: 57; Тиханова 1953, с. 431, рис. 1: 13 , 16, 46; Якобсон 1979 , с. 101 , рис. 63 : $76-82$, 85-86, 103); TPC IL (Моисеев 2014b, с. 284, 304, рис. 3).

Class 2. Variants: $3-5,21$. Upper edge: RE/MH. Side flange: Tf/H. Lower edge: bend $\left(\geq 135^{\circ}\right) / \mathrm{WD}$. Were found on: CH (Klenina et al. 2018, p. 185, fig. 12: 133/10); ЕK (Моисеев 2018b, с. 191-192, 195, рис. 16: 12; 17: I; 20: 7); MK (Моисеев 2014b, с. 288; Романчук 1977 , с. 186 - 187 , рис. 5: 45; 6: 61; Якобсон 1979 , c. 101 , рис. 63 : 110-112); VAR (Якобсон 1970, с. 159, табл. III: 10); TPC IL (Моисеев 2014b, с. 284, 304, рис. 3).

Class 3. Variants: 2, 9-10, 14. Upper edge: Ref/MH. Side flange: Tf/H. Lower edge: bend $\left(\geq 135^{\circ}\right) / \mathrm{WD}$. Were found on: EK (Моисеев 2018b, с. 191, рис. 16: II); МK (Мыц 1990, с. 230, рис. 6: 33-34; Романчук 1977 , с. 184 , рис. 3: 32; Якобсон 1979, с. 101 , рис. 63 : 76-82); TPC IL (Моисеев 2014b, с. 284, 304, рис. 3).

Class 4. Variants: 8, 11-12, 15. Upper edge: Ref/ M-H. Side flange: Tf/L. Lower edge: bend $\left(\approx 90^{\circ}\right) / \mathrm{WD}$. Were found on: EK (Моисеев 2018b, с. 192, рис. 17: II); MK (Моисеев 2014b, с. 288); TPC IL (Моисеев 2014b, с. 284,304 , рис. 3$)$.

\section{SUBGROUP I/ 5}

Class 1. Variants: 4, 6-7, 9, 11-13, 15. Upper edge: Ref/M-H. Side flange: Tf/H. Lower edge: bend $\left(\geq 135^{\circ}\right.$ on the outer side, $\approx 90^{\circ}$ on the inner side) / WD, with narrowing. Were found on: CH (Романчук 2004, табл. 9: Н12/135, Н13; рис. 23: 4; Симонова 1980, с. 106 , рис. 1: 23-24; 2: 12; Якобсон 1979, с. 95, рис. 58: 135); EK (Моисеев 2018b, с. 199-200, рис. 24: I; 25; 26: II; 28; 29: I-II; 30: II); VAR (Якобсон 1970, с. 159, табл. III: $12,16-17)$.

Class 2. Variants: 1, 3, 5. Upper edge: Ref/H. Side flange: Tf/M. Lower edge: bend $\left(\geq 135^{\circ}\right) / \mathrm{BD}$ on the inner side. Were found on: EK (Моисеев 2018b, с. 198199, рис. 23; 24: II); TPC IL (Моисеев 2014b, с. 285 , 304, рис. 3).

Class 3. Variant: 10. Upper edge: Tf/M. Side flange: $\mathrm{Tf} / \mathrm{H}$. Lower edge: bend $\left(\geq 135^{\circ}\right) / \mathrm{BD}$, with narrowing. Were found on: EK (Моисеев 2018b, с. 202, рис. 27).

\section{SUBGROUP I/ 6}

Variant: 1. Upper edge: Tf/M. Side flange: Tf/H. Lower edge: unknown. Were found on: EK (Моисеев 2018b, с. 196, рис. 21: I).

\section{GROUP Ich}

\section{SUBGROUP Ich / 1}

Class 1. Variants: 1, 5-6, 10. Upper edge: Tf/H. Side flange: Tf/M. Lower edge: bend $\left(\geq 135^{\circ}\right) / \mathrm{BD}$, without tail. Were found on: CH (Klenina et al. 2018, p. 179-180, fig. 6; 7: 210/10—211/10, 214/10, 236/10; Романчук 2004, табл. 7: E37; 14: N2/177, N5/177в, 32, УР20/37, 48, У3102/228; Симонова 1980, с. 111, 
рис. 2: 50, 56; Якобсон 1979, с. 149-150, рис. 97: 37, 177, 288); ЕK (Моисеев 2018b, с. 206, рис. 31: II; осcasional finds).

Class 2. Variant: 7. Upper edge: Tf/M. Side flange: $\mathrm{Tf} / \mathrm{H}$. Lower edge: bend $\left(\approx 90^{\circ}\right) / \mathrm{BD}$. Were found on: CH (Klenina et al. 2018, p. 180, fig. 7: 101/10; Якобсон 1979 , с. 150 , рис. $97 ; 235)$.

Class 3. Variants: 8-9. Upper edge: 3f/H. Side flange: $3 \mathrm{f} / \mathrm{H}$. Lower edge: unknown. Were found on: $\mathrm{CH}$ (Klenina et al. 2018, p. 180, fig. 7: 167/10, 171/10).

\section{SUBGROUP Ich / 2}

Class 1. Variants: 1, 3, 15, 30. Upper edge: Tf/H. Side flange: Tf/M. Lower edge: bend $\left(\approx 90^{\circ}\right) / \mathrm{WD}$. Were found on: CH (Klenina et al. 2018, p. 152-153, 175, 177, fig. 2: group 1, subgroup A, v. 13; 4: 99-100; Романчук 2004, табл. 25: У319/295, У318, 41, УР57/39; рис. 53: УР57(39), 53, УР61(30); Якобсон 1979, с. 149-150, рис. 96: 30, 39; 97: 295-296); ЕK (Моисеев 2018b, c. 208 -209, рис. 33 : III: 13 ; 34: II).

Class 2. Variants: $4-5,7-12,14,16-22,25-26$, 35-36, 39-41. Upper edge: 3f/H-M, holes of fingerprints. Side flange: $3 \mathrm{f} / \mathrm{H}$, finger-print ditch under the bottom of the flange. Lower edge: bend $\left(\geq 135^{\circ}\right) / \mathrm{WD}$, sometimes with narrowing. Were found on: $\mathrm{CH}$ (Klenina et al. 2018, p. 151, 176-179, fig. 3; 4: 58/09, 99/10, 103/10, 106/10; 5: 26/09, 140/10, 147/10; Романчук 2004, табл. 3: Г11/249; 6: E26/222, E27/223; 7: Е3032; 25: У322/298, У323-25, У326/306; 33: УР22/25; 37: УР36/48, УР37/49; 42: E53/117, рис. 21: 3; 41: 2; 42: 1 ; 47: 3; 52: 3; 53: 3; Симонова 1980, с. 110 , рис. 2 : 36, 58; 3: 49; Якобсон 1979, с. $149-150$, рис. 96: 25, 38, 49, 52, 61; 97: 116-117, 222-223, 249, 305-307); EK (Моисеев 2018b, с. 208, рис. 33: 12; Паршина 1988, с. 43 , рис. $3: 215$; occasional finds).

Class 3. Variants: 6, 23. Upper edge: 3f/H. Side flange: 3f/M. Lower edge: bend $\left(\approx 90^{\circ}\right) /$ WD. Were found on: CH (Klenina et al. 2018, p. 177, fig. 4: 102/10; Романчук 2004, табл. 23: Ф6/221; Якобсон 1979, c. 150, рис. 97: 220-221); EK (occasional finds).

\section{SUBGROUP Ich $/ 3$}

Variants: $1-3$. Upper edge: unknown. Side flange: Tf/M. Lower edge: short bend $\left(\approx 90^{\circ}\right) /$ WD. Were found on: CH (Klenina et al. 2018, p. 180, fig. 7: 49/09, 84/10, 95/09, 107/09; Романчук 2004, табл. 22: Р4/245, рис. 27: 2; 53: 2; Якобсон 1979, с. $149-150$, рис. 96: 35-36; 97: 245); Ilyaz-Kaya (Паршина 1974, с. 82, рис. 20: 34).

\section{SUBGROUP Ich / 4}

Upper edge: Tf/M, espessilly broad upper edge. Side flange: Ref/H. Lower edge: bend $\left(\geq 135^{\circ}\right) / \mathrm{WD}$, bend $\left(\approx 90^{\circ}\right) / \mathrm{BD}$. Were found on: $\mathrm{CH}$ (Klenina et al. 2018, p. 180, fig. 7: 1/09); TPC on the North side of Akhtiar bау (Рыжова 1982, p. 153).

\section{SUBGROUP Ich $/ 5$}

Upper edge: clear. Side flange: Ref/H, upper cutaway. Lower edge: without bend, lower cutaway. Were found on: СН (Моисеев 2013b, с. 170-171, 185, рис. 5; Романчук 1976, с. 156-157, рис. 1: 1); MK (Герцен, Манаев 2005, с. 322-325).

\section{GROUP II \\ SUBGROUP II/ 1}

Class 1. Variants: 6, 17. Upper edge: FTF or clear. Side flange: Tf/M. Lower edge: bend $\left(90-135^{\circ}\right) / \mathrm{WD}$. Were found on: CH (Яшаева и др. 2018b, с. 123); ТНtemple (Тесленко, Мусин 2015, с. 131, рис. 3.9: 67).

Class 2. Variant: 7. Upper edge: Tf/L or FTF. Side flange: Tf/H. Lower edge: bend $\left(\geq 135^{\circ}\right) / \mathrm{WD}$. Were found on: СН (Яшаева и др. 2018b, с. 123).

Class 3. Variants: 8-10, 13, 15. Upper edge: Tf/ L. Side flange: Ref/M. Lower edge: bend $\left(\geq 135^{\circ}\right) /$ WD. Were found on: CH (Романчук 2004, табл. 8: Е49; Яшаева и др. 2018b, с. 123); settlement Simeiz (Паршина 1974, с. 85, 87, рис. 27: 16); TH-temple (Тесленко, Мусин 2015, с. 121, 124, рис. 3.1: 47, 101, 120; 3.4: 56, 70, 110).

Class 4. Variant: 2. Upper edge: Ref/H. Side flange: Tf/H. Lower edge: unknown. Were found on: EK (Моисеев 2018b, с. 210, рис. 35: III).

Class 5. Variant: 1. Upper edge: Tf/M. Side flange: $3 \mathrm{f} / \mathrm{H}$, bad defined (smooth) transition to the surface. Lower edge: unknown. Were found on: ЕК (Моисеев 2018a, с. 210 , рис. $35:$ II; Паршина 1988, с. 41 , рис. 3 : 11); VAR (Якобсон 1970, с. 159, табл. III: 36).

Class 6. Variants: 3, 5. Upper edge: REf/H. Side flange: Tf/M, bad defined (smooth) transition to the surface. Lower edge: unknown, perhaps without bend. Were found on: EK (Моисеев 2018a, с. 210, рис. 35: 9); PART.85-88.

\section{SUBGROUP II/2}

Class 1. Variants: $1-7,9,11,13-14$. Upper edge: 3f/H, REf/M, Tf/L. Side flange: Tf/M. Lower edge: bend $\left(\geq 135^{\circ}\right) / \mathrm{WD}, \mathrm{II} / 2 / 7$ with bend $\left(\geq 135^{\circ}\right) / \mathrm{BD}$. Were found on: $\mathrm{CH}$ (Klenina et al. 2018, p. 184, fig. 11: 85/09, 87-88/10; Бернацки, Кленина 2006, с. 110 , рис. 6: 2; Романчук 2004, табл. 4: Е3/109; 5: E4/106; 9: H1/130, H2, H3/134, H5/132; 12: M8/189; 17: К43, рис. $22: 1-2 ; 32$ : 4; 39: 2; Симонова 1980 , с. 106 , рис. 1: 21; Якобсон 1979, с. 95, рис. 58: 108-109); EK (Завадская 2008, с. 313 , рис. 3: 6-7, 10-12, 14; Моисеев 2018b, с. 211-213, рис. 36: II; 37; 38: I; Паршина 1988 , с. 40 , рис. 3: 9-11, 17-26); settlement Laspi (Паршина 1974, с. 82, рис. 20: 8); MK (Романчук 1976, с. 186 , рис. 4: 40); settlement Oreanda (Паршина 1974 , с. 88 , рис. $30: 3$ ); PART.85-88 (Моисеев 2018b, с. 162, рис. 9: 1, 17; Паршина 1991, рис. 4: 11); VAR (Якобсон 1970, с. 159, табл. III: 2832); Ilyaz-Kaya (Паршина 1974, с. 82 , рис. 20: 6-7); Isar-Кауа (Мыц 1987 , с. $231-232$, рис. 4: 12-14); UC-temple (Моисеев 2018a, с. 162, рис. 8: 2).

Class 2. Variant: 8. Upper edge: REf/M. Side flange: 3f/M. Lower edge: without bend, lower cutaway. Were found on: UC-temple (Моисеев 2018a, с. 162, рис. 8: $1)$.

Class 3. Variants: 10, 12. Upper edge: Tf/H. Side flange: Tf/L, the joint of the upper and side flanges is some below of the upper corner on side flange and it is determined by the changing of the height and shape of the flange. Lower edge: without bend, lower cutaway. Were found on: CH (Романчук 2004, табл. 10: H23/207; 14: N11(Н23)/207; 27: У351; Якобсон 1979, с. 96, рис. 59; 207); Gurzuf (Паршина 1974, с. 90, рис. 32: 4); PART.85-88 (Моисеев 2018a, с. 162, рис. 9: 2-4); settlement Oreanda (Паршина 1974, с. 88, рис. 30: 2); settlement Upper Massandra (Паршина 1974, с. 89, рис. 31: 13). 


\section{SUBGROUP $I I / 3$}

Class 1. Variants: 1, 4, 7, 9, 17, 22, 28, 30-33. Upper edge: REf/H, Tf/L-M. Side flange: Tf/H. Lower edge: bend $\left(\geq 135^{\circ}\right) / \mathrm{WD}$, sometimes with narrowing. Were found on: Alupka-Isar (Паршина 1974, c. 86, 88, рис. 28); CH (Klenina et al. 2018, p. 159, 183, fig. 10: 24/09; Романчук 2004, табл. 11: $\Lambda 17 / 242$; Якобсон 1979, с. 95, рис. 58: 3, 14); ЕК (Завадская 2008, с. 314, рис. 4: 2, 12, 16; Моисеев 2018b, с. 215, 217, 225, рис. 40; 42: I; 44: I; 45: I; 49: II; 50: 9; Паршина 1988, c. 41 , рис. $3: 84$ ); MK (Тиханова 1953, с. 431 , рис. 1 : 59-60; Якобсон 1979, с. 66 , рис. 38: 16-17); VAR (Якобсон 1970, с. 159, табл. III: $1-2$ ).

Class 2. Variants: 5-6, 8, 18-19, 21, 23-24. Upper edge: REf/H, Tf/M. Side flange: Tf/M. Lower edge: unknown. Were found on: CH (Klenina et al. 2018, p. 183 , fig. 10: 122/10; Романчук 2004, табл. 14: N12/188, N13, N14/188в; 47: У3110/158, рис. 11: 4; 37: 4; 38: 4; 50: 3; Симонова 1980, с. 105,111 , рис. $1: 3$; 2 ; 59-60; Якобсон 1979, с. 95, рис. 58: 9-10, 158, 313); EK (Завадская 2008, с. 314, рис. 4: 1, 3-4; Моисеев 2018b, с. $217-219$, 225 , рис. 42 : II; 43; 44: II; 47: II; 50: 3; Паршина 1988, с. 42 , рис. 3 : $114-118$ ); VAR (Якобсон 1970, с. 159, табл. III: 22, 43); settlement Upper Massandra (Паршина 1974, с. 89, рис. 38: 16-17); Ilyaz-Kaya (Паршина 1974, с. 82 , рис. 20: $36)$.

Class 3. Variants: 12, 16, 20, 29. Upper edge: REf/H Side flange: Tf/L. Lower edge: bend $\left(\geq 135^{\circ}\right) / \mathrm{WD}$, narrowing. Were found on: CH (Klenina et al. 2018, p. 184, fig. 10: 127/10; Симонова 1980, с. 111, рис. 2: 52-54; Романчук 2004, табл. 25: УЗ14/282, УЗ15, У316, 27, У341; Якобсон 1979, с. 96, рис. 59: 256-257); ЕK (Завадская 2008, с. 314, рис. 4: 14; Моисеев 2018b, с. 221, 224-225, рис. 46: II; 49: I; 50: 1; Паршина 1988 , с. 38 , рис. 2 : 12 ); PART.85-88; VAR (Якобсон 1970, с. 159 , табл. III: 18); Ilyaz-Kaya (Паршина 1974 , с. 82 , рис. 20: 38); Isar-Кауа (Мыщ 1987, с. 231, рис. 4: 20).

Class 4. Variant: 15. Upper edge: Tf/M. Side flange: $\mathrm{Tf} / \mathrm{H}$. Lower edge: bend $\left(\approx 90^{\circ}\right) / \mathrm{WD}$, short tail. Were found on: СН (Симонова 1980, с. 106, рис. 1: 22; 2: 8-10; Романчук 2004, табл. 12: М1/139, М2/140, рис. 26: 2-3; Якобсон 1979, с. 95, рис. 58: 139-141); EK (Моисеев 2018b, с. 223, рис. 48; Паршина 1988, c. 38 , рис. 2: 11); settlement Laspi (Паршина 1974, c. 78,82 , рис. $18: 12 ; 20: 14$ ); MK (Мыц 1990, с. 230, рис. 6: 35); VAR (Якобсон 1970 , с. 159 , табл. III: 51); Ilyaz-Kaya (Паршина 1974, с. 82 , рис. 20: 15-16); Isar-Kaya (Мыц 1987, с. 231, рис. 4: 10).

Class 5. Variant: $10-11,13-14,27$. Upper edge: REf/M. Side flange: $3 \mathrm{f} / \mathrm{H}$. Lower edge: bend $\left(\geq 135^{\circ}\right)$ WD, narrowing. Were found on: $\mathrm{CH}$ (Klenina et al. 2018, p. 184, fig. 11: 66/09); EK (Завадская 2008, с. 314 , рис. 4 : $10-11$; Моисеев 2018b, с. $220-221$, рис. 45: II; 46: I, III).

\section{SUBGROUP II/4}

Variants: 1-4. Upper edge: FTF or clear. Side flange: Tf/M. Lower edge: bend $\left(\geq 135^{\circ}\right) / \mathrm{WD}$ bend $\left(\geq 135^{\circ}\right)$ or $\mathrm{BD}$ on the inner side of the flange. Were found on: СН (Романчук 1990, с. 167, 243, рис. 5: 4, 6; Романчук 2004, рис. 9: 4; 16: 1-2; Симонова 1980, c. 106 , рис. 1 : 27 ; Якобсон 1979, с. $25-26$, рис. 10 : 251; 11: 2); settlement Oreanda (Паршина 1974, с. 88, рис. 30: 27); PART.85-88 (Паршина 1991, рис. 4: 6, 12); TPC IK (Паршина 1974, с. 82 , рис. 20: 39; 1993, с. 188 , рис. $47:$ В).

\section{SUBGROUP II/5}

Class 1. Variants: 1, 3, 9-11. Upper edge: Tf/ M. Side flange: Tf/M. Lower edge: bend $\left(\geq 135^{\circ}\right) /$ WD. Were found on: CH (Романчук 2004, табл. 29: уз65в/286; рис. 43: 5; Якобсон 1979, с. 150 , рис. 97: 286); PART.85-88 (Паршина 1991, рис. 4: 5); ТНtemple (Тесленко, Мусин 2015, с. 124, рис. 3.4: 5, 8); UC-temple (Моисеев 2018a, с. 161, рис. 6: 4-6).

Class 2. Variant: 6. Upper edge: REf/L. Side flange: 3f/M. Lower edge: bend $\left(\geq 135^{\circ}\right) /$ WD. Were found on: CH (Романчук 2004, табл. 4: $\Delta 4 / 148, \Delta 5 ; 42: \Delta 14 / 148$; Якобсон 1979, с. 95, 101, рис. 58: 148; 63: 16); settlement Limena (Паршина 1974, с. $85-86$, рис. 26: 5); MK (Тиханова 1953, с. 431, рис. 1: 55); PART.85-88 (Паршина 1991, рис. 4: 3); Biuk-Isar (Паршина 1974, с. 84 , рис. $22: 6$ ).

\section{SUBGROUP II/ 6}

Class 1. Upper edge: clear or FTF. Side flange: REf/ M. Lower edge: bend $\left(\geq 135^{\circ}\right) / \mathrm{BD}$ on the outer side of the flange. Were found on: TH-temple (Тесленко, Мусин 2015, с. 131 , рис. 3.9: 48, 63); ТPC К.

Class 2. Upper edge: clear or FTF. Side flange: Tf/ M. Lower edge: unknown. Were found on: TH-temple (Тесленко, Мусин 2015, с. 134, рис. 3.12: 57, 111); TPC K.

\section{SUBGROUP II/ 7}

Class 1. Variant: 1. Upper edge: ROf/M. Side flange: Tf/L. Lower edge: bend $\left(\geq 135^{\circ}\right) /$ WD. Were found on: PART.85-88.

Class 2. Variant: 2. Upper edge: Tf/M. Side flange: $\mathrm{Tf} / \mathrm{H}$. Lower edge: bend $\left(\geq 135^{\circ}\right) / \mathrm{WD}$. Were found on: PART.85-88 (Паршина 1991, рис. 4: 8).

Class 3. Variant: 3. Upper edge: Tf/M. Side flange: REf/M. Lower edge: bend $\left(\geq 135^{\circ}\right) /$ WD. Were found on: PART.85-88; TH-temple (Тесленко, Мусин 2015, с. 129,268 , рис. $3.7: 3)$.

\section{SUBGROUP II/ 8}

Class 1. Variants: 1-2. Upper edge: REf/M. Side flange: Tf/M. Lower edge: bend $\left(\geq 135^{\circ}\right) / \mathrm{WD}$. Were found on: TH-temple (Тесленко, Мусин 2015, с. 121, 129, рис. 3.1: 36; 3.7: 50); TPC IK.

Class 2. Variant: 4. Upper edge: REf/M. Side flange: $\mathrm{Tf} / \mathrm{H}$. Lower edge: bend $\left(\geq 135^{\circ}\right) / \mathrm{BD}$, on the inner side of the flange. Were found on: PART.85-88 (Паршина 1991, рис. 4: 2)

\section{SUBGROUP II/9}

Variant: 1. Upper edge: REf/M. Side flange: Tf/M. Lower edge: bend $\left(\geq 135^{\circ}\right) / \mathrm{WD}$, sometimes BD on the inner side of the flange. Were found on: $\mathrm{CH}$ (Klenina et al. 2018, p. 181, fig. 8; Романчук 2004, табл. 8: E47/ 145в; Якобсон 1979, с. 95, рис. 58: 104); Ilyaz-Kaya (Паршина 1974, с. 82 , рис. 20: 2); Temple to the South from the Biya-Sala ${ }^{1}$.

1. Excavations were managed by D. V. Masuta in 2012. Unpublicized. Author is grateful to Mr. Masuta for the sanction to take this material. 


\section{SUBGROUP II/ 10}

Class 1. Variant: 1. Upper edge: Tf/L. Side flange: Tf/ M. Lower edge: unknown. Were found on: $\mathrm{CH}$ (Яшаева и др. 2018b, с. 123).

Class 2. Variant: 2. Upper edge: Tf/M. Side flange: Tf/M. Lower edge: unknown. Were found on: CH (Яшаева и др. 2018b, с. 123).

\section{SUBGROUP II/ 11}

Upper edge: REf/H. Side flange: ROf/L, Tf/M. Lower edge: unknown. Were found on: СН (Яшаева и др. 2018b, c. 123); PART.85-88.

\section{SUBGROUP II/12}

Upper edge: clear upper edge. Side flange: Tf (with complicated profile)/M. Upper cutaway. Lower edge: without bend, lower cutaway. Were found on: $\mathrm{CH}$ (Моисеев 2013b, с. 169-170, 184, рис. 4: II); ТРC В (Моисеев 2013b, с. 169-170, 184, рис. 4: III).

\section{GROUP III}

\section{SUBGROUP III/ 1}

Class 1. Upper edge: REf/H. Side flange: REf/H. Lower edge: unknown. Were found on: TPC S.

Class 2. Upper edge: unknown. Side flange: $\mathrm{Tf} / \mathrm{H}$. Lower edge: bend $\left(\geq 135^{\circ}\right) / \mathrm{WD}$. Were found on: TPC $\mathrm{S}$.

\section{SUBGROUP III/2}

Variants: $1-2$. Upper edge: clear or FTF. Side flange: $\mathrm{REf} / \mathrm{H}, \mathrm{Tf} / \mathrm{H}$. Lower edge: bend $\left(\geq 135^{\circ}\right) / \mathrm{BD}$ on the inner side of the flange. Were found on: $\mathrm{CH}$ (Романчук 1990, с. 167, 244, рис. 7: 1); MK (Моисеев 2011, с. 178, рис. 3: 32-36; Мыц 1990, с. 229, рис. 5: 4-5); Suren (Воронин и др. 1990, с. 461, 463, 474, рис. 10: 7); ТРС S.

\section{SUBGROUP III/3}

Class 1. Variant: 1. Upper edge: Tf/L, sometimes with complicated profile. Side flange: Tf/H. Lower edge: bend $\left(\geq 135^{\circ}\right) /$ WD. Were found on: CH (Яшаева и др. 2018b, с. 123); MK (Науменко 1997, с. 327,338 , рис. 1: 1-2); «Markevich's basilica» ${ }^{1}$.

Class 2. Variants: 2-3. Upper edge: Tf/L. Side flange: REf/H. Lower edge: bend $\left(\geq 135^{\circ}\right) /$ WD. Were found on: MK (Моисеев 2011, с. 178, рис. 3: 30, 52); «Markevich's basilica».

\section{SUBGROUP III / 4}

Upper edge: REf/H. Side flange: Tf/L. Lower edge: unknown. Were found on: TPC S.

\section{SUBGROUP III/ 5}

Upper edge: Tf/L. Side flange: Tf/H. Lower edge: bend $\left(\geq 135^{\circ}\right) /$ WD. Were found on: TPC S.

1. Survey was managed by author in 2013. Unpublicized.

\section{SUBGROUP III/ 6}

Variants: $1-3$. Upper edge: Ref/M. Side flange: Tf/ M. Lower edge: bend $\left(\geq 135^{\circ}\right) / \mathrm{WD}$, sometimes there is short tail. Were found on: CH (Klenina et al. 2018, p. 186, fig. 13: 135/10, 178/10, 283/10; 156, рис. 48: 3); EK (Моисеев 2018b, с. 225, рис. 50: III); PART.85-88; TPC S.

\section{GROUP IV}

\section{SUBGROUP IV/1}

Upper edge: Tf/M. Side flange: Tf/M, the joint of the upper and side flanges is some below of the upper corner on side flange and it is determined by the changing of the height and shape of the flange. Lower edge: without bend, lower cutaway. Were found on: $\mathrm{CH}$ (Klenina et al. 2018, p. 160, 173, 186, fig. 13: 97-99/10; 17: л. 15, рис. 26: 9, 12; Рыжов, Седикова 1999, с. 323 , рис. $12: 8,14)$.

\section{SUBGROUP IV/2}

Upper edge: clear. Side flange: Tf/M. Lower edge: without bend, lower cutaway. Were found on: $\mathrm{CH}$ (Klenina et al. 2018, p. 160-161, 173, 187-188, fig. 14 : 70—71/10, 73/10, 95/10; 15).

\section{SUBGROUP IV/3}

Upper edge: Tf/M. Side flange: Tf/M, the joint of the upper and side flanges is some below of the upper corner on side flange and it is determined by the changing of the height and shape of the flange. Lower edge: without bend, lower cutaway. Were found on: $\mathrm{CH}$ (Klenina et al. 2018, p. 187, fig. 14: 285/10); Тaman (Чхаидзе и др. 2017, с. 276, ил. 25: 3).

\section{ЛITЕРАТУРА}

Айбабин, А. И., Хайрединова, Э. А. 2011. Позднесредневековая часовня на плато Эски-Кермен. Материаль по археологии, истории и этнографбии Таврии, 17, с. 422-457.

Бернацки, А. Б., Клёнина, Е. Ю. (ред.). 2006. Топограббия Херсонеса Таврического. Водосборная иистерна жилого дола в квартале VII (IX-XI вв.). Херсонесский сборник, Supplement I. Севастополь: Максим.

Воронин, Ю. С., Майко, В. В., Кутайсов, В. А. 2014. Археологические раскопки Сюйреньского укрепления 1978-79 гг. Раскоп I. История и археология Kрылма, 1, с. 458-479.

Герцен, А. Г., Манаев, А. Ю. 2005. Демир-Капу в системе оборонительных сооружений Мангупа. Материаль по археологии, истории и этнограбби Таврии, 11, с. 314-345.

Голофаст, Л. А., Рыжов, С. Г. 2003. Раскопки квартала Х в северном районе Херсонеса. Материаль по археологии, истории и этнографбии Таврии, 10, c. $182-260$.

Домбровский, О. И. 1974. Средневековые поселения и «Исары» Крымского Южнобережья. В: Бибиков, С. Н. (ред.). Феодальная Таврика. Киев: Наукова думка, с. 5-56.

Завадская, И. А. 2008. Серии черепиц с ремесленными знаками из Эски-Кермена (по материалам раскопок 2003-2005 гг.) Материаль по археологии, истории и этнограбби Таврии, 14, с. 291-315. 
Завадская, И. А. 2010. Проблемы изучения кровельного материала средневековых центров ЮгоЗападного Крыма. Труды Государственного Эрлитажа, 53, с. 252-266.

Калинина, Т. М., Флёров, В. С., Петрухин, В. Я. 2014. Хазария в кросскультурнол пространстве. Историческая география. Крепостная архитектура. Выєбор веры. Москва: ЛитРес.

Лысенко, А. В., Тесленко, И. Б. 2002. Античные и средневековые памятники горы Аю-Даг. В: Рудницкая, В. Г., Тесленко, И. Б. (ред.). Алушта и Алуштинский регион с древнейших врелён и до наших дней. Киев: Стилос, с. 59-88.

Моисеев, Д. А. 2011. Археологический комплекс строительной керамики IX-X вв. из раскопок поселения в Лагерной Балке (Мангуп). Древности, 10, с. $172-190$.

Моисеев, Д. А. 2013. Ранневизантийская черепица из раскопок цистерны в центральном неде базилики «Крузе» в Херсонесе. Материаль по археологии, истории и этнографбии Таврии, 18, с. 162-186.

Моисеев, Д. А. 2014а. Керамиды «хазарского» и «фемного» времени из раскопок Илькинского производственного центра. Степи Европь в эпоху средневековья, 12, с. 278-318.

Моисеев, Д. А. 2014b. Комплекс строительной керамики XIV в. из раскопок христианского храма в округе горы Илька. Материаль по археологии, истории и этнографби Таврии, 19, с. 278-310.

Моисеев, Д.А. 2015. Технология производства строительной керамики из раскопок Семикаракорского городища (конец VIII - начало IX вв.). Хазарский альманах, 13, с. 156-179.

Моисеев, Д. А. 2018а. Керамиды из раскопок храма на м. Безымянный: аналогии и хронология. В: Яшаева, Т. Ю. (ред.). Археология античного и средневекового города. Сборник статей в честь Станислава Григорьевича Рыжова. Севастополь; Калининград: РОСТ ДОАФК, с. 149-162.

Моисеев, Д. А. 2018b. Строительная керамика из раскопок «пещерного города" Эски-Кермен в 19361937 гг.: каталог предметов из фондов Бахчисарайского музея-заповедника. Археологія $i$ давня історія України, 4 (29), с. 165-225.

Моисеев, Д. А., Корженков, А. М., Овсюченко, А. Н., Ларьков, А. С. 2019. Крымское разрушительное землетрясение второй половины XV в. Вопросы инженерной сейслологии, 46, 2, с. 37-53.

Моисеев, Д. А., Чудин, А. В. 2014. Исследования гончарного центра в балке ручья Суаткан (южная периферия Мангупского городища). Археологічні дослідження в Україні 2013 р., с. 61.

Моисеев, Д. А., Смекалова, Т. Н., Чудин, А. В. 2013. Археологические разведки в уроч. Суаткан на перифрерии Мангупского городища. Археологічні дослідження в Україні 2012 р., с. 72-73.

Мыц, В. Л. 1987. Средневековое укрепление ИсарКая. Советская археология, 2, с. 228-246.

Мыщ, В. Л. 1990. Крестообразный храм Мангупа. Советская археология, 1, с. 224-243.

Мыц, В. Л. 2009. Каббба и Феодоро в XV веке. Контакты и конфбликты. Симферополь: Универсум.

Науменко, В. Е. 1997. Раскопки раннесредневекового поселения у подножия Мангупа. Бахчисарайский историко-археологический сборник, 1, с. 324-340.

Науменко, В. Е., Душенко, А. А. 2017. Княжеский дворец Мангупского городища: помещение Н южного участка комплекса (по материалам коллекции P. Х. Лепера Государственного Эрмитажа и современных археологических исследований). Материа- ль по археологии, истории и этнографби Таврии, 22 , c. $187-238$.

Науменко, В. Е., Душенко, А. А., Корзюк, Д. В., Моисеев, Д. А., Чудин, А. В. 2013. Исследования средневековых памятников Адым-Чокракской долины крымских предгорий. Археологічні дослідження в Україні 2013 р., с. 66-69.

Паршина, Е. А. 1974. Средневековая керамика Южной Таврики. В: Бибиков, С. Н. (ред.). Феодальная Таврика. Киев: Наумова думка, с. 56-94.

Паршина, Е. А. 1988. Эски-Керменская базилика. В: Бибиков, С. Н. (ред.). Архитектурно-археологические исследования в Крыму. Киев: Наукова думка, с. 36-59.

Паршина, Е. А. 1991. Торжище в Партенитах. В: Толочко, П. П., Мыц, В. Л., Зубарь, В. М. Византийская Таврика. Киев: Наукова думка, с. 64-100.

Паршина, Е. А. 1993. Керамический комплекс в урочище Чобан-Таш (Юго-Западный склон г. ИльясКая). Археологічні дослідження на Украйні 1991 р., c. $107-110$.

Паршина, Е. А. 2002. Древний Партенит (по материалам раскопок 1985-1988 гг.). В: Рудницкая, В. Г., Тесленко, И. Б. (ред.). Алушта и Алуштинский регион с древнейших врелён и до наших дней. Киев: Стилос, с. 89-109.

Паршина, Е. А., Тесленко, И. Б., Зеленко, С. М. 2001. Гончарные центры Таврики VIII-X вв. В: Гладких, В. І. (ред.). Морська торгівля в Північнолу Причорнолор'ї. Київ: Стилос, с. 52-81.

Романчук, А. И. 1976. Ранневизантийская строительная керамика Херсонеса. Византийский временник, 37, с. 156-159.

Романчук, А. И. 1977. Черепицы со знаками из раскопок на Мангупе. Советская археология, 2, c. $181-192$.

Романчук, А. И. 1990. Западный загородный храм Херсонеса. Византийский временник, 51, с. 165171.

Романчук, А. И. 2004. Строительные материальь византийского Херсона. Екатеринбург: Уральский университет.

Романчук, А. И., Сазанов, А. В., Седикова, Л. В. 1995. Алиборы из колплексов византийского Херсона. Екатеринбург: Уральский университет.

Рудаков, В. Е. 1984. Христианские памятники Баклы. Храмовый комплекс X-XIII вв. Античная древность и средние века, 21, с. 33-57.

Рыжов, С. Г. 2001. Средневековые жилые кварталы X-XIII вв. в Северном районе Херсонеса. Mатериаль по археологии, истории и этнографби Таврuи, 8, с. 290-311.

Рыжов, С. Г. 1998. Отчёт о раскопках X квартала "б" в Северном районе Херсонеса в 1998 году. Текст. Науковий архів Національного заповідника «Херсонес Таврійський», д. 3381.

Рыжов, С. Г., Седикова, Л. В. 1999. Комплексы $\mathrm{X}$ века из раскопок квартала X «б» Северного района Херсонеса. Херсонесский сборник, 10, с. 312-330.

Рыжова, Л. А. 1982. Гончарная печь VIII-IX вв. вблизи Херсона (в районе Радиогорки). Античная древность и средние века, 19, с. 149-156.

Савеля, О.Я. 1989. Отчёт о разведках в низовье p. Бельбек. Текст. Науковий архів Національного заповідника «Херсонес Таврійський», д. 2912/III.

Сазанов, А. В. 1999. Базилика 1987 г. и проблемы интерпретации памятников христианского Херсонеса. Причернолорье в средние века, 4, с. 276-316.

Сарновски, Т. 2005. Римская черепица Южного Крыма. Материаль по археологии, истории и этнографбии Таврии, 11, с. 119-143. 
Сарновски, Т., Савеля, О. Я., (ред.). 2000. Балаклава. Рилская военная база и святилище Юпитера Долихена. Swiatowit, Supplement Series A: Antiquity, 5. Warschau: Instytut Archeologii UW.

Смекалова, Т. Н., Науменко, В. Е., Кулькова, М. А., Завадская, И. А., Беван, Б. В. Естественнонаучные методы в изучении средневекового керамического центра Илька 2 в Горном Крыму и его продукции. Краткие сообщения Института археологии, 258, с. 326-339.

Симонова, Т. И. 1980. Метки на черепице кровли дома XIII-XIV вв. Античная древность и средние века, 17, с. 104-120.

Талис, Д. Л. 1968. Черепицы с метками из раскопок Баклинского городища. Советская археология, 2, с. 184-196.

Терещенко, Е. Ю., Завадская, И. А., Антипин, А. М., Кварталов, В. Б., Мандрыкина, А. В., Лобода, А. Ю., Хмеленин, Д. Н., Васильев, А. Л., Яцишина, Е. Б., Алексеева, Е. Б. 2020. Естественно-научные исследования керамики из Эски-Кермена. Кристаллографбия, 65, 2, с. 314-324.

Тесленко, И. Б. 2020. Керамика Эски-Кермена эпохи «посткатастрофы» (по материалам исследо-

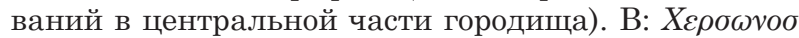

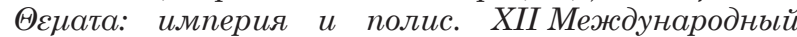
Византийский селинар. Симферополь: Колорит, c. $249-254$

Тесленко, И. Б., Мусин, Е. А. (ред.). 2015. Древности Семидворья I. Средневековый двухапсидный храли в урочище Еди-Евлер (Алушта, Крыл): исследования и материаль. Археологический альманах, 32. Киев: Антиквар.

Тиханова, М. А. 1953. Черепицы с метками из раскопок 1938 г. Материаль и исследования по археологии СССР, 34, с. 430-432.

Филиппенко, А. А. 1998. Строительные керамические материалы с пунктов дислокации римских войск в Кадыковке и на высоте Казацкой. Херсонесский сборник, 9, с. 110-118.

Фирсов, Л. В. 1990. Исары: Очерки истории средневековых крепостей Южного берега Крылиа. Новосибирск: Наука.

Флёров, В. С. 1995. Правобережное Цимлянское городище в свете раскопок 1987-1988, 1990 гг. Мaтериаль по археологии, истории и этнографии Таврии, 4, с. 441-516.

Чхаидзе, В. Н., Виноградов, А. Ю., Ёлшин, Д. Д. 2017. Средневековый храм на Таманском городище и его архитектурный контекст. Труды Государственного Эрлитажа, 86, с. 257-407

Якобсон, А. Л. 1950. Средневековый Херсонес (XII-XIV вв.). Материалы исследования по археологии СССР, 17. Москва; Ленинград: Наука.

Якобсон, А. Л. 1970. Раннесредневековые сельские поселения Юго-Западной Таврики. Материалы и исследования по археологии СССР, 168. Ленинград: Наука.

Якобсон, А. Л. 1979. Керамика и керамическое производство средневековой Таврики. Москва: Наука.

Яшаева, Т. Ю. 2005. Хазарско-булгарский храм в предместье византийского Херсона. In: Cojocaru, V. (ed.). Ethnic Contacts and Cultural Exchanges North and West of the Black Sea from the Greek Colonization to the Ottoman Conquest. Iasi: Trinitas, c. 481-493.

Яшаева, Т. Ю., Денисова, Е. А., Голофаст, Л. А. Моисеев, Д. А. 2018а. Раннехристианский пещерный комплекс на юго-восточном некрополе Херсонеса. В: Яшаева, Т. Ю. (ред.). Археология античного и средневекового города: сборник статей в честь Станислава Григорьевича Рыжова. Севастополь; Калининград: РОСТ ДОАФК, с. 333-362.

Яшаева, Т. Ю., Денисова, Е. А., Голофраст, Л. А., Моисеев, Д. А. 2018b. Христианский комплекс на Девичьей горе в свете новых археологических исследований. В: III Свято-Владилирские чтения: Материаль международной научной коноберенции, посвящённой 1030-летию Крещения Руси. Севастополь: Телескоп, с. 121-126.

Color Munsell (org.) 1996. Munsell soil color charts. Year 2000 revised washable edition. New Windsor: GretagMacbeth.

Klenina, E. Ju., Moisieiev, D. A., Biernacki, A. B. 2018. The building ceramics of the Byzantine Chersonesus Taurica: form and chronology. Novae. Studies and Materials: Sacrum et Profanum, 6: Haec studia amici et college Andrei B. Biernacki septuagennio dicant, p. 147-188.

Moisieiev, D. 2018. Tile Production Workshop of the Golden Horde Period in Crimea. XI AIECM3 Uluslararası Orta Çăg ve Modern Akdeniz Dünyası Seramik Kongresi Bildirileri. Istambul: Koç Universitesi Yayınları, p. 259-262.

\section{REFERENCES}

Aibabin, A. I., Khairedinova, E. A. 2011. Pozdnesrednevekovaia chasovnia na plato Eski-Kermen. Materialy po arkheologii, istorii i etnografii Tavrii, 17, s. 422-457.

Bernatski, A. B., Klenina, E. Iu. (eds.). 2006. Topografiia Khersonesa Tavricheskogo. Vodosbornaia tsisterna zhilogo doma v kvartale VII (IX-XI vv.). Khersonesskii sbornik, Supplement I. Sevastopol: Maksim.

Voronin, Iu. S., Maiko, V. V., Kutaisov, V. A. 2014. Arkheologicheskie raskopki Siuirenskogo ukrepleniia 1978-79 gg. Raskop I. Istoriia i arkheologiia Kryma, 1, s. 458-479.

Gertsen, A. G., Manaev, A. Iu. 2005. Demir-Kapu v sisteme oboronitelnykh sooruzhenii Mangupa. Materialy po arkheologii, istorii i etnografii Tavrii, 11, s. 314-345.

Golofast, L. A., Ryzhov, S. G. 2003. Raskopki kvartala X v severnom raione Khersonesa. Materialy po arkheologii, istorii i etnografii Tavrii, 10, s. 182-260.

Dombrovskii, O. I. 1974. Srednevekovye poseleniia i «Isary» Krymskogo Iuzhnoberezhia. In: Bibikov, S. N. (ed.). Feodalnaia Tavrika. Kiev: Naukova dumka, s. 5-56.

Zavadskaia, I. A. 2008. Serii cherepits s remeslennymi znakami iz Eski-Kermena (po materialam raskopok 20032005 gg.) Materialy po arkheologii, istorii i etnografii Taurii, 14 , s. 291-315.

Zavadskaia, I. A. 2010. Problemy izucheniia krovelnogo materiala srednevekovykh tsentrov Iugo-Zapadnogo Kryma. Trudy Gosudarstvennogo Ermitazha, 53, s. 252-266.

Kalinina, T. M., Flerov, V. S., Petrukhin, V. Ia. 2014. Khazariia $v$ krosskulturnom prostranstve. Istoricheskaia geografiia. Krepostnaia arkhitektura. Vybor very. Moskva: LitRes.

Lysenko, A. V., Teslenko, I. B. 2002. Antichnye i srednevekovye pamiatniki gory Aiu-Dag. In: Rudniczkaya, V. G., Teslenko, I. B. (eds.). Alushta $i$ Alushtinskii region s drevneishikh vremen i do nashikh dnei. Kiev: Stilos, s. 59-88.

Moiseev, D. A. 2011. Arkheologicheskii kompleks stroitelnoi keramiki IX-X vv. iz raskopok poseleniia v Lagernoi Balke (Mangup). Drevnosti, 10, s. 172-190.

Moiseev, D. A. 2013. Rannevizantiiskaia cherepitsa iz raskopok tsisterny v tsentralnom nefe baziliki «Kruze» v Khersonese. Materialy po arkheologii, istorii $i$ etnografii Tavrii, 18 , s. $162-186$.

Moiseev, D. A. 2014a. Keramidy «khazarskogo» i «femnogo» vremeni iz raskopok Ilkinskogo proizvodstvennogo tsentra. Stepi Evropy v epokhu srednevekovia, 12, s. 278-318.

Moiseev, D. A. 2014b. Kompleks stroitelnoi keramiki XIV v. iz raskopok khristianskogo khrama v okruge gory Ilka. Materialy po arkheologii, istorii i etnografii Tavrii, 19, s. 278310. 
Moisieiev, D. A. Medieval Flanged Tiles from the South-Western Crimea...

Moiseev, D. A. 2015. Tekhnologiia proizvodstva stroitelnoi keramiki iz raskopok Semikarakorskogo gorodishcha (konets VIII - nachalo IX vv.). Khazarskii almanakh, 13, s. 156-179.

Moiseev, D. A. 2018a. Keramidy iz raskopok khrama na m. Bezymiannyi: analogii i khronologiia. In: Iashaeva, T. Iu. (ed.). Arkheologiia antichnogo $i$ srednevekovogo goroda. Sbornik statei v chest Stanislava Grigorevicha Ryzhova. Sevastopol; Kaliningrad: ROST DOAFK, s. 149-162.

Moiseev, D. A. 2018b. Stroitelnaia keramika iz raskopok "peshchernogo goroda" Eski-Kermen v 1936-1937 gg.: katalog predmetov iz fondov Bakhchisaraiskogo muzeia-zapovednika. Arkheolohiia i davnia istoriia Ukrainy, 4 (29), s. 165225

Moiseev, D. A., Korzhenkov, A. M., Ovsiuchenko, A. N., Larkov, A. S. 2019. Krymskoe razrushitelnoe zemletriasenie vtoroi poloviny XV v. Voprosy inzhenernoi seismologii, 46, 2, s. $37-53$.

Moiseev, D. A., Chudin, A. V. 2014. Issledovaniia goncharnogo tsentra $\mathrm{v}$ balke ruchia Suatkan (iuzhnaia periferiia Mangupskogo gorodishcha). Arkheolohichni doslidzhennia $v$ Ukraini 2013 r., s. 61.

Moiseev, D. A., Smekalova, T. N., Chudin, A. V. 2013. Arkheologicheskie razvedki v uroch. Suatkan na periferii Mangupskogo gorodishcha. Arkheolohichni doslidzhennia v Ukraini 2012 r., s. 72-73.

Myts, V. L. 1987. Srednevekovoe ukreplenie Isar-Kaia. Sovetskaia arkheologiia, 2, s. 228-246

Myts, V. L. 1990. Krestoobraznyi khram Mangupa. Sovetskaia arkheologiia, 1, s. 224-243.

Myts, V. L. 2009. Kaffa i Feodoro v XV veke. Kontakty $i$ konflikty. Simferopol: Universum.

Naumenko, V. E. 1997. Raskopki rannesrednevekovogo poseleniia u podnozhiia Mangupa. Bakhchisaraiskii istorikoarkheologicheskii sbornik, 1, s. 324-340.

Naumenko, V. E., Dushenko, A. A. 2017. Kniazheski dvorets Mangupskogo gorodishcha: pomeshchenie N iuzhnogo uchastka kompleksa (po materialam kollektsii R. Kh. Lepera Gosudarstvennogo Ermitazha i sovremennykh arkheologicheskikh issledovanii). Materialy po arkheologii, istorii $i$ etnografii Taurii, 22, s. 187-238.

Naumenko, V. E., Dushenko, A. A., Korziuk, D. V., Moiseev, D. A., Chudin, A. V. 2013. Issledovaniia srednevekovykh pamiatnikov Adym-Chokrakskoi doliny krymskikh predgorii. Arkheolohichni doslidzhennia v Ukraini 2013 r., s. 66-69.

Parshina, E. A. 1974. Srednevekovaia keramika Iuzhnoi Tavriki. In: Bibikov, S. N. (ed.). Feodalnaia Tavrika. Kiev: Naumova dumka, s. 56-94.

Parshina, E. A. 1988. Eski-Kermenskaia bazilika. In Bibikov, S. N. (ed.). Arkhitekturno-arkheologicheskie issledovaniia v Krymu. Kiev: Naukova dumka, s. 36-59.

Parshina, E. A. 1991. Torzhishche v Partenitakh. In: Tolochko, P. P., Myts, V. L., Zubar, V. M. Vizantiiskaia Taurika Kiev: Naukova dumka, s. 64-100.

Parshina, E. A. 1993. Keramicheskii kompleks v urochish che Choban-Tash (Iugo-Zapadnyi sklon g. Ilias-Kaia). Arkheolohichni doslidzhennia na Ukraini 1991 r., s. 107-110.

Parshina, E. A. 2002. Drevnii Partenit (po materialam raskopok 1985-1988 gg.). In: Rudniczkaya, V. G., Teslenko, I. B. (eds.). Alushta $i$ Alushtinskii region s drevneishikh vre men $i$ do nashikh dnei. Kiev: Stilos, s. 89-109.

Parshina, E. A., Teslenko, I. B., Zelenko, S. M. 2001. Goncharnye tsentry Tavriki VIII-X vv. In: Hladkykh, V. I. (ed.) Morska torhivlia v Pivnichnomu Prychornomor’i. Kyiv: Stylos, s. 52-81.

Romanchuk, A. I. 1976. Rannevizantiiskaia stroitelnaia keramika Khersonesa. Vizantiiskii vremennik, 37, s. 156-159.

Romanchuk, A. I. 1977. Cherepitsy so znakami iz raskopok na Mangupe. Sovetskaia arkheologiia, 2, s. 181-192.

Romanchuk, A. I. 1990. Zapadnyi zagorodnyi khram Khersonesa. Vizantiiskii vremennik, 51, s. 165-171.

Romanchuk, A. I. 2004. Stroitelnye materialy vizantiiskogo Khersona. Ekaterinburg: Uralskii universitet.

Romanchuk, A. I., Sazanov, A. V., Sedikova, L. V. 1995. Amfory iz kompleksov vizantiiskogo Khersona. Ekaterinburg: Uralskii universitet.

Rudakov, V. E. 1984. Khristianskie pamiatniki Bakly. Khramovyi kompleks X-XIII vv. Antichnaia drevnost $i$ srednie veka, 21, s. 33-57.
Ryzhov, S. G. 2001. Srednevekovye zhilye kvartaly XXIII vv. v Severnom raione Khersonesa. Materialy po arkheologii, istorii i etnografii Tavrii, 8, s. 290-311.

Ryzhov, S. G. 1998. Otchet o raskopkakh X kvartala «b» v Severnom raione Khersonesa v 1998 godu. Tekst. Naukovyi arkhiv Natsionalnoho zapovidnyka "Khersones Tavriiskyi», d. 3381 .

Ryzhov, S. G., Sedikova, L. V. 1999. Kompleksy X veka iz raskopok kvartala X «b» Severnogo raiona Khersonesa. Khersonesskii sbornik, 10, s. 312-330.

Ryzhova, L. A. 1982. Goncharnaia pech VIII-IX vv. vblizi Khersona (v raione Radiogorki). Antichnaia dreunost $i$ srednie veka, 19 , s. 149-156.

Savelia, O. Ia. 1989. Otchet o razvedkakh v nizove r. Belbek. Tekst. Naukovyi arkhiv Natsionalnoho zapovidnyka «Khersones Tavriiskyi», d. 2912/III

Sazanov, A. V. 1999. Bazilika $1987 \mathrm{~g}$ i problemy interpretatsii pamiatnikov khristianskogo Khersonesa. Prichernomore v srednie veka, 4 , s. 276-316.

Sarnovski, T. 2005. Rimskaia cherepitsa Iuzhnogo Kryma. Materialy po arkheologii, istorii i etnografii Tavrii, 11, s. 119-143.

Sarnovski, T., Savelia, O. Ia., (ed.). 2000. Balaklava. Rimskaia voennaia baza $i$ sviatilishche Iupitera Dolikhena. Światowit, Supplement Series A: Antiquity, 5. Warschau: Instytut Archeologii UW.

Smekalova, T. N., Naumenko, V. E., Kulkova, M. A., Zavadskaia, I. A., Bevan, B. V. Estestvennonauchnye metody $\mathrm{v}$ izuchenii srednevekovogo keramicheskogo tsentra Ilka $2 \mathrm{v}$ Gornom Krymu i ego produktsii. Kratkie soobshcheniia Instituta arkheologii, 258, s. 326-339.

Simonova, T. I. 1980. Metki na cherepitse krovli doma XIIIXIV vv. Antichnaia dreunost $i$ srednie veka, 17, s. 104-120.

Talis, D. L. 1968. Cherepitsy s metkami iz raskopok Baklinskogo gorodishcha. Sovetskaia arkheologiia, 2, s. 184-196.

Tereshchenko, E. Iu., Zavadskaia, I. A., Antipin, A. M., Kvartalov, V. B., Mandrykina, A. V., Loboda, A. Iu., Khmelenin, D. N., Vasilev, A. L., Iatsishina, E. B., Alekseeva, E. B. 2020. Estestvenno-nauchnye issledovaniia keramiki iz EskiKermena. Kristallografiia, 65, 2, s. 314-324.

Teslenko, I. B. 2020. Keramika Eski-Kermena epokhi "postkatastrofy» (po materialam issledovanii v tsentralnoi

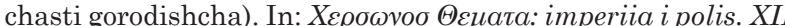
Mezhdunarodnyi Vizantiiskii seminar. Simferopol: Kolorit, s. $249-254$

Teslenko, I. B., Musin, E. A. (ed.). 2015. Drevnosti Semidvoria I. Srednevekovyi dvukhapsidnyi khram v urochishche Edi-Evler (Alushta, Krym): issledovaniia i materialy. Arkheologicheskii almanakh, 32. Kiev: Antikvar.

Tikhanova, M. A. 1953. Cherepitsy s metkami iz raskopok 1938 g. Materialy $i$ issledovaniia po arkheologii SSSR, 34, s. $430-432$.

Filippenko, A. A. 1998. Stroitelnye keramicheskie materialy s punktov dislokatsii rimskikh voisk v Kadykovke i na vysote Kazatskoi. Khersonesskii sbornik, 9, s. 110-118.

Firsov, L. V. 1990. Isary: Ocherki istorii srednevekovykh krepostei Iuzhnogo berega Kryma. Novosibirsk: Nauka.

Flerov, V. S. 1995. Pravoberezhnoe Tsimlianskoe gorodishche v svete raskopok 1987-1988, 1990 gg. Materialy po arkheologii, istorii $i$ etnografii Tavrii, 4, s. 441-516.

Chkhaidze, V. N., Vinogradov, A. Iu., Elshin, D. D. 2017. Srednevekovyi khram na Tamanskom gorodishche i ego arkhitekturnyi kontekst. Trudy Gosudarstvennogo Ermitazha, 86, s. 257-407

Iakobson, A. L. 1950. Srednevekovyi Khersones (XII$X I V v v$.). Materialy issledovaniia po arkheologii SSSR, 17. Moskva; Leningrad: Nauka.

Iakobson, A. L. 1970. Rannesrednevekovye selskie poseleniia Iugo-Zapadnoi Tavriki. Materialy i issledovaniia po arkheologii SSSR, 168. Leningrad: Nauka.

Iakobson, A. L. 1979. Keramika i keramicheskoe proizvodstvo srednevekovoi Tavriki. Moskva: Nauka.

Iashaeva, T. Iu. 2005. Khazarsko-bulgarskii khram v predmeste vizantiiskogo Khersona. In: Cojocaru, V. (ed.). Ethnic Contacts and Cultural Exchanges North and West of the Black Sea from the Greek Colonization to the Ottoman Conquest. Iasi: Trinitas, s. 481-493.

Iashaeva, T. Iu., Denisova, E. A., Golofast, L. A., Moiseev, D. A. 2018a. Rannekhristianskii peshchernyi kompleks 
na iugo-vostochnom nekropole Khersonesa. In: Iashaeva, T. Iu. (ed.). Arkheologiia antichnogo i srednevekovogo goroda: sbornik statei v chest Stanislava Grigorevicha Ryzhova. Sevastopol; Kaliningrad: ROST DOAFK, s. 333-362.

Iashaeva, T. Iu., Denisova, E. A., Golofast, L. A., Moiseev, D. A. 2018b. Khristianskii kompleks na Devichei gore v svete novykh arkheologicheskikh issledovanii. In: III SviatoVladimirskie chteniia: Materialy mezhdunarodnoi nauchnoi konferentsii, posviashchennoi 1030-letiiu Kreshcheniia Rusi. Sevastopol: Teleskop, s. 121-126.

Color Munsell (org.) 1996. Munsell soil color charts. Year 2000 revised washable edition. New Windsor: GretagMacbeth.

Klenina, E. Ju., Moisieiev, D. A., Biernacki, A. B. 2018. The building ceramics of the Byzantine Chersonesus Taurica: form and chronology. Novae. Studies and Materials: Sacrum et Profanum, 6: Haec studia amici et college Andrei B. Biernacki septuagennio dicant, p. 147-188.

Moisieiev, D. 2018. Tile Production Workshop of the Golden Horde Period in Crimea. XI AIECM3 Uluslararası Orta Çağ ve Modern Akdeniz Dünyası Seramik Kongresi Bildirileri. Istambul: Koç Universitesi Yayınları, p. 259-262.

\section{A. Moiseiev}

\section{MEDIEVAL FLANGED TILES FROM THE SOUTH-WESTERN CRIMEA: PROBLEMS OF PRODUCTION LOCALIZATION, TYPOLOGY AND CHRONOLOGY}

The article is the first comprehensive research on the medieval building ceramics of the South-Western Crimea. The study has systematized a large amount of material sources from various archaeological sites located throughout the region. The method used for the study includes the typology that combines both technological and morphological features of products. This kind of description of building ceramics is comprehensive and can be used for the study of material of various geographical and historical habitats.

Medieval building ceramics of the South-Western Crimea were investigated using the technology-morphological typology, which made it a reliable indicator of chronology. The systematization of the material showed a developed tile production craft in the medieval South-Western Crimea. Chronological identification of the material in the classification allowed to trace the development of this craft in dynamics. Some products of tile production centers have been dated with an accuracy of up to two decades due to its technological and morphological definition on the different archaeological sites.

Tile production centers were found in Chersonesos, near Eski-Kermen and Mangup (Ilka, Suatkan), Chufut-Kale and Bakla (Bodrak), in Laspi (Ilyaz-Kaya and Batiliman), in the Alushta region (Kanaka, ChobanKule). At least two tile production centers belonging to subgroups II/2, II/5 and II/8-II/12 remain unknown or unidentified. With help of technology-morphological typology we separated imports from two unknown pottery centers.

It should be noted that materials from different tile production centers were found systematically on different archaeological objects throughout the South-Western Crimea. Further study of Flanged tiles' morphological features could make the typology a more important chronological indicator in the dating of building ceramics than stratigraphic context is now. This situation confirms that the technology-morphological typology has the potential to be a universal one.
Keywords: flanged tile, building ceramics, SouthWestern Crimea, typology, chronology, tile production center.

\section{Д. А. Моісеєв}

\section{СЕРЕДНЬОВІЧНА ЧЕРЕПИЦЯ (КЕРАМІДИ) ПІВДЕННО-ЗАХІДНОГО КРИМУ: ПРОБЛЕМИ ЛОКАЛІЗАЦЇ̈ ВИРОБНИЦТВА, ТИПОЛОГЇ̈ I ХРОНОЛОГІї}

Ця стаття є першим комплексним дослідженням середньовічноїбудівельноїкераміки Південно-Західного Криму. У роботі систематизовано велику кількість матеріальних джерел. Вони походили з різних археологічних пам'яток, розташованих по всьому регіону. Метод, що використовуеться для дослідження, включає типологію, яка поєднує як технологічні, так і морфологічні характерні риси продукції. Цей вид опису будівельної кераміки є універсальним і може бути використаний для вивчення черепиці різних географрічних та історичних середовищ.

Середньовічна будівельна кераміка ПівденноЗахідного Криму досліджувалась за допомогою технологічно-морфологічної типології, яка зробила iï надійним хроноіндикатором. Систематизація матеріалу показала наявність у середньовічному Південно-Західному Криму розвинутого ремесла 3 виробництва будівельної кераміки. Хронологічна ідентифікація матеріалу в рамках класифікації дозволила простежити розвиток цього ремесла в динаміці. Для продукції окремих гончарних центрів хронологію вдалося встановити з точністю до двох десятиріч.

Гончарні центри було зафіксовано в Херсонесі, біля Ескі-Кермена та Мангупа (Ілька і Суаткан), Чуфут-Кале й Бакли (Бодрак), у Ласпі (Ільяз-Кая і Батилиман), у районі Алушти (Канака, Чобан-Куле). Залишаються невідомими або неідентифрікованими мінімум два гончарних центри, які відносяться до підгруп II/2, II/5 і II/8-II/12. Використання технолого-морфологічної типології також дозволило виокремити імпорт із двох невідомих гончарних центрів.

Зазначимо, що матеріал різних гончарних центрів було знайдено не на одній пам'ятці археології, а систематично на різних об'єктах на всій території Південно-Західного Криму. Подальше вивчення морфологічних особливостей керамід може зробити типологію більш важливим хронологічним показником при датуванні будівельної кераміки, ніж стратиграфічний контекст. Така ситуація підтверджуе, що технолого-морфологічна типологія дійсно має потенціал універсальної.

Ключові слова: кераміда, будівельна кераміка, Південно-Західний Крим, типологія, хронологія, гончарний центр по виробництву черепиці.

Одержано 28.05.2021

MOICЄСВ Дмитро Анатолійович, кандидат історичних наук, експерт, ГО «Кримський інститут стратегічних досліджень», Київ, Україна.

MOISIEIEV Dmytro A., Ph D, expert, CO «Crimean institute of strategic studies», Kyiv, Ukraine.

ORCID: 0000-0003-2434-4409, e-mail: ohota_d@ukr.net. 